\title{
Site U1419'
}

\author{
J.M. Jaeger, S.P.S. Gulick, L.J. LeVay, H. Asahi, H. Bahlburg, C.L. Belanger, G.B.B. Berbel, L.B. Childress, \\ E.A. Cowan, L. Drab, M. Forwick, A. Fukumura, S. Ge, S.M. Gupta, A. Kioka, \\ S. Konno, C.E. März, K.M. Matsuzaki, E.L. McClymont, A.C. Mix, C.M. Moy, J. Müller, A. Nakamura, \\ T. Ojima, K.D. Ridgway, F. Rodrigues Ribeiro, O.E. Romero, A.L. Slagle, J.S. Stoner, \\ G. St-Onge, I. Suto, M.H. Walczak, and L.L. Worthington ${ }^{2}$
}

\section{Chapter contents}

Background and objectives. .......... Operations....................... 2 Lithostratigraphy............... Paleontology and biostratigraphy .......8 Stratigraphic correlation............9 Geochemistry .................. 11 Physical properties .............. 14 Paleomagnetism ................ 16 Core-log-seismic integration. . . . . . . . . 17 References................. 18

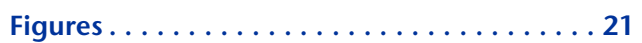

Tables. ......................67

1Jaeger, J.M., Gulick, S.P.S., LeVay, L.J., Asahi, H., Bahlburg, H., Belanger, C.L., Berbel, G.B.B., Childress, L.B., Cowan, E.A., Drab, L., Forwick, M., Fukumura, A., Ge, S., Gupta, S.M., Kioka, A., Konno, S., März, C.E., Matsuzaki, K.M., McClymont, E.L., Mix, A.C., Moy, C.M., Müller, J., Nakamura, A., Ojima, T., Ridgway, K.D., Rodrigues Ribeiro, F., Romero, O.E., Slagle, A.L.,Stoner, J.S., St-Onge, G., Suto, I., Walczak, M.H., and Worthington, L.L., 2014. Site U1419. In Jaeger, J.M., Gulick, S.P.S., LeVay, L.J., and the Expedition 341 Scientists, Proc. IODP, 341: College Station, TX (Integrated Ocean Drilling Program). doi:10.2204/iodp.proc.341.105.2014

2Expedition 341 Scientists' addresses.

\section{Background and objectives}

Site U1419 is located at $721 \mathrm{~m}$ water depth on a gently sloping bank on the continental slope above the Khitrov Ridge (Fig. F1). We informally refer to the feature as Khitrov bank. The site is within the influence of the surface Alaska Coastal Current (Stabeno et al., 2004; Weingartner et al., 2005) and at depths possibly influenced by deeply rooted surface eddies and the North Pacific Intermediate Water. Drilling objectives at the site exploited the preservation of carbonate microfossils and associated geochronologic methods that can be used to develop a high-temporal resolution, proximal sedimentary record of Late Pleistocene glacial dynamics and paleoceanography (Davies et al., 2011; Addison et al., 2012). A primary objective is to constrain the timing of multiple glacial events of the Pacific side of the northwestern Cordilleran ice sheet to test its relation to the dynamics of global ice sheets. An allied goal is to understand the role of North Pacific sea-surface temperatures as a control on the glacial system over the Late Pleistocene, potentially with decadal or century resolution in glaciated and laminated intervals. The proximity of the site to regions of seasonally high surface productivity (Ladd et al., 2007) allows us to address the dynamics of productivity and intermediate water circulation on hypoxia in the northeast Pacific and the role of these processes in the global carbon cycle. The probability for an independent and highly resolved radiocarbon and oxygen isotopic chronology (Davies et al., 2011) offers the potential to document the interrelationship between paleomagnetic intensity and secular variation in the Pacific in comparison with other global records.

Coring results and high-resolution compressed high-intensity radar profiler (CHIRP) and multichannel seismic (MCS) reflection data reveal a complex depositional setting. This location is $\sim 30$ $\mathrm{km}$ west of the Bering Trough mouth, which may have been the terminus of the Bering Glacier at the Last Glacial Maximum (Carlson and Bruns, 1997; Berger et al., 2008) (Fig. F1). Site U1419 was surveyed during Cruise EW0408, resulting in a jumbo piston core ( $11.5 \mathrm{~m}$ long) that contains a deglacial ( 17.5 k.y.) to modern sedimentary record of hemipelagic and glacimarine sedimentation (Barron et al., 2009; Davies et al., 2011; Addison et al., 2012). Seismic reflection data (Fig. F2) reveal a range of seismic facies (Fig. F3) that likely reflect the time-varying input of glacigenic sediment interspersed with biogenic-rich hemipelagic facies. Pro- 
cessed CHIRP images (Fig. F3), coincident with the MCS profiles, reveal that an upper postglacial transparent layer on the profile corresponds to the upper $\sim 8 \mathrm{~m}$ of the sediment in Core EW0408-85JC, which dates to younger than $14.7 \mathrm{ka}$ (Davies et al., 2011). Higher amplitude reflections in the CHIRP line and from the sediment/water interface to $\sim 0.03 \mathrm{~s}$ twoway traveltime (TWT) $(\sim 8-25 \mathrm{~m})$ in MCS Line GOA3201 likely represent glacimarine sediments associated with the local Last Glacial Maximum (Fig. F3). It is hypothesized that the less reflective layered sediments in the MCS profile represent interstadial events, when the Bering Glacier terminus retreated relative to the shelf break and ice rafting of sediment was much reduced or absent. In contrast, the highly reflective intervals could indicate times when ice rafting was active, causing higher accumulation rates of coarser glacigenic sediment. Active faulting is imaged in high-resolution seismic Profile GOA3101, showing surface deformation indicative of significant amounts of extension or transtension (Fig. F3A) (Worthington et al., 2008). Seismic units for Site U1419 are discussed in detail in "Core-log-seismic integration." They include seismic Units A-K (Fig. F4) and were selected based on seismic facies, possibly reflecting changes in glacial proximity.

\section{Operations}

\section{Transit to Site U1419}

After a $47 \mathrm{nmi}$ transit from Site U1418 averaging 9.9 $\mathrm{kt}$, the vessel arrived at the third expedition site. The vessel stabilized over Site U1419 at 2118 h (UTC - 8 h) on 9 July 2013, and the positioning beacon was deployed at $2135 \mathrm{~h}$. The position reference was a combination of GPS signals and a single acoustic beacon.

\section{Site U1419}

Site U1419 consists of five holes (Table T1), ranging in depth from 98.7 to $193.0 \mathrm{~m}$ drillers depth below seafloor (DSF) (Fig. F5). A total of 101 cores were recovered for the site. The interval cored with the advanced piston corer (APC) system was $517.9 \mathrm{~m}$, with $473.0 \mathrm{~m}$ recovered $(91 \%)$. The interval cored with the extended core barrel (XCB) system was $74.4 \mathrm{~m}$, with $14.86 \mathrm{~m}$ recovered (20\%). The overall recovery for Site U1419 was $82 \%$. Total time spent on Site U1419 was 4.1 days.

\section{Hole U1419A}

Hole U1419A was spudded at $0200 \mathrm{~h}$ on 10 July 2013. A mudline core (341-U1419A-1H) recovered $7.43 \mathrm{~m}$ of sediment, and seafloor was calculated to be at 687.4 meters below sea level (mbsl). Nonmagnetic core barrels and the APC system were used for Cores $1 \mathrm{H}$ through $12 \mathrm{H}$. APC coring with wireline continued through Core $20 \mathrm{H}$ with the half APC coring system using steel core barrels. Partial APC strokes were recorded on Cores $5 \mathrm{H}, 8 \mathrm{H}, 9 \mathrm{H}, 11 \mathrm{H}$ through $13 \mathrm{H}, 15 \mathrm{H}$, and $17 \mathrm{H}$ through $20 \mathrm{H}$. APC core recovery was affected by frequently encountered large clasts. The XCB system was deployed with a soft-formation cutting shoe for Cores $21 \mathrm{X}$ through 29X to $193.0 \mathrm{~m}$ DSF. Hole U1419A was terminated after Core $29 \mathrm{X}$ at $0235 \mathrm{~h}$ on 11 July. At the conclusion of coring, the hole was plugged with $85 \mathrm{bbl}$ of $10.5 \mathrm{ppg}$ mud and then abandoned. The top drive was set back, and the drill string was pulled from the hole. A total of 20 APC cores were taken over a 118.6 $\mathrm{m}$ interval, with $96.38 \mathrm{~m}$ recovered $(81 \%)$. A total of nine XCB cores were cut over a $74.4 \mathrm{~m}$ interval, with $14.86 \mathrm{~m}$ recovered $(20 \%)$. The overall recovery for Hole U1419A was $111.24 \mathrm{~m}$ for the $193.0 \mathrm{~m}$ cored interval (58\%). Total time spent on Hole U1419A was $30.5 \mathrm{~h}$.

\section{Hole U1419B}

After clearing the seafloor, the vessel was offset $20 \mathrm{~m}$ east of Hole U1419A. Hole U1419B was spudded at $0530 \mathrm{~h}$ on 11 July 2013 . The mudline core recovered $8.53 \mathrm{~m}$ of sediment, and seafloor was calculated to be at $687.1 \mathrm{mbsl}$. Nonmagnetic core barrels were used and FlexIT orientation was performed for Cores 341-U1418B-1H through $10 \mathrm{H}$. After Core $10 \mathrm{H}$, the half APC system was deployed. The hole was advanced from Core $11 \mathrm{H}$ through Core $19 \mathrm{H}$ to $114.0 \mathrm{~m}$ DSF. A $1 \mathrm{~m}$ interval was drilled without coring from 109.6 to $110.6 \mathrm{~m}$ DSF. Partial strokes of the coring systems occurred on Cores $6 \mathrm{H}, 8 \mathrm{H}$ through $10 \mathrm{H}$, $13 \mathrm{H}, 17 \mathrm{H}$, and $19 \mathrm{H}$. APC recovery was affected by frequently encountered large clasts. Coring in Hole $\mathrm{U} 1419 \mathrm{~B}$ was terminated at $114.0 \mathrm{~m}$ DSF at $1740 \mathrm{~h}$ on 11 July. The hole was displaced with $48 \mathrm{bbl}$ of 10.5 ppg mud, and the drill string was tripped from the hole with the top drive installed. The seafloor was cleared at $1940 \mathrm{~h}$ on 11 July, ending Hole U1419B. A total of 18 APC cores were taken over a $113.0 \mathrm{~m}$ interval, with $99.05 \mathrm{~m}$ recovered (88\%). Total time spent on Hole U1419B was 15.9 h.

\section{Hole U1419C}

After clearing the seafloor, the vessel was offset $20 \mathrm{~m}$ south of Hole U1419B. The bit was then spaced out and lowered to the first shot depth, and Hole U1419C was spudded at $2100 \mathrm{~h}$ on 11 July 2013. An offset water depth of $685.8 \mathrm{mbsl}$ (tide corrected) was used after averaging the tide-corrected water depths from the two previous holes. Hole U1419C was 
washed down to $2.0 \mathrm{~m}$ DSF, and coring with nonmagnetic core barrels took place for Cores 341U1419C-2H through $11 \mathrm{H}(2.0-78.7 \mathrm{~m}$ DSF). Partial strokes were recorded on Cores $5 \mathrm{H}, 7 \mathrm{H}, 9 \mathrm{H}, 10 \mathrm{H}$, $14 \mathrm{H}$ through $17 \mathrm{H}$, and $19 \mathrm{H}$. The Core Barrel-Drill String Acceleration Tool was run on Cores $2 \mathrm{H}$ through $10 \mathrm{H}$ as an extension on the APC/XCB core barrel between $2020 \mathrm{~h}$ on 11 July and $0450 \mathrm{~h}$ on 12 July in order to record drill bit acceleration and vibration signals during drilling. However, the tool malfunctioned downhole, and only $\sim 30 \mathrm{~min}$ of reasonable data were recorded. Upon recovery, it was discovered that several supporting screws in the tool were broken, and it seems likely that excessive internal vibration led to small cracks in the sensors, producing intermittent tool response. Cores $11 \mathrm{H}$ through $20 \mathrm{H}$ (78.7-109.1 m DSF) were recovered using the half APC system. APC recovery was affected by frequently encountered large clasts. Hole U1419C was terminated at $1230 \mathrm{~h}$ on 12 July. The hole was displaced with $43 \mathrm{bbl}$ of $10.5 \mathrm{ppg}$ mud, and the drill string was tripped from the hole with the top drive installed. The seafloor was cleared at $1425 \mathrm{~h}$ on 12 July, ending Hole U1419C. A total of 19 APC cores were taken over a $107.1 \mathrm{~m}$ interval, with $100.37 \mathrm{~m}$ recovered (94\%). Total time spent on Hole U1419C was $18.8 \mathrm{~h}$.

\section{Hole U1419D}

After clearing the seafloor, the vessel was offset $40 \mathrm{~m}$ west of Hole U1419C. The bit was then spaced out and lowered to the first shot depth, and Hole U1419D was spudded at $1720 \mathrm{~h}$ on 12 July 2013. An offset water depth of $687.5 \mathrm{mbsl}$ (tide corrected) was used after averaging the tide-corrected water depths from the first two holes at the site. After spudding Hole U1419D, the hole was washed down to $5.5 \mathrm{~m}$ DSF and Cores 341-U1419D-2H through $14 \mathrm{H}$ were recovered from 5.5 to $80.1 \mathrm{~m}$ DSF. Partial strokes were recorded on Cores $6 \mathrm{H}, 8 \mathrm{H}, 9 \mathrm{H}, 11 \mathrm{H}, 12 \mathrm{H}, 14 \mathrm{H}$, $17 \mathrm{H}, 21 \mathrm{H}, 23 \mathrm{H}$, and $24 \mathrm{H}$. After Core $14 \mathrm{H}$, the half APC coring system was deployed, and coring continued through Core $24 \mathrm{H}$ to $114.2 \mathrm{~m}$ DSF. The hole was displaced with $40 \mathrm{bbl}$ of $10.5 \mathrm{ppg}$ mud, and the drill string was tripped from the hole with the top drive installed. The seafloor was cleared at $0810 \mathrm{~h}$ on 13 July, ending Hole U1419D. A total of 20 APC cores were taken over a $103.7 \mathrm{~m}$ interval, with $105.10 \mathrm{~m}$ recovered (101\%). Three intervals were drilled without coring, which added up to $10.5 \mathrm{~m}$. Total time spent on Hole U1419D was 17.75 h.

\section{Hole U1419E}

After clearing the seafloor, the vessel was offset $20 \mathrm{~m}$ north of Hole U1419D. An offset water depth of
685.5 mbsl (tide corrected) was used after averaging the tide-corrected water depths from the first two holes at the site. Hole U1419E was spudded at 0900 h on 13 July 2013 and washed down to $9.0 \mathrm{~m}$ DSF. Cores $341-\mathrm{U} 1419 \mathrm{E}-2 \mathrm{H}$ through $12 \mathrm{H}$ were recovered from 9.0 to $69.0 \mathrm{~m}$ DSF. Partial strokes were recorded on Cores $4 \mathrm{H}, 6 \mathrm{H}, 8 \mathrm{H}, 9 \mathrm{H}, 11 \mathrm{H}, 12 \mathrm{H}, 18 \mathrm{H}$, and $19 \mathrm{H}$. After Core $12 \mathrm{H}$, the half APC coring system was deployed, and coring continued through Core $19 \mathrm{H}$ to 98.7 m DSF. Coring was terminated at $1900 \mathrm{~h}$ on 13 July. The hole was displaced with $38 \mathrm{bbl}$ of $10.5 \mathrm{ppg}$ mud, the drill string was tripped back to $46.4 \mathrm{~m}$ DSF, and the top drive was set back. The drill string was then tripped back to the surface, and the bottomhole assembly was set back in the derrick. The bit cleared the rotary table at $2315 \mathrm{~h}$, the drill floor was secured, and the thrusters were secured for transit at $0030 \mathrm{~h}$ on $14 \mathrm{July}$, ending Hole U1419E and Site U1419. A total of 15 APC cores were taken over a $75.5 \mathrm{~m}$ interval with $72.1 \mathrm{~m}$ recovered (95.5\%). Four intervals were drilled without coring, with a combined length of $23.2 \mathrm{~m}$. Total time spent on Hole U1419E was $16.25 \mathrm{~h}$.

\section{Lithostratigraphy}

Lithologic summaries of the five holes drilled at Site U1419 are shown in Figure F6. The sediment recovered at Site U1419 contains 14 facies. Detailed facies descriptions, information about common marine microfossils, facies occurrence in lithostratigraphic units, and tentative interpretations about depositional environments are summarized in Table $\mathrm{T} 2$. The dominant facies (F1a, F1b, F4e, and F4f) are dark gray (N 4) to dark greenish gray (10Y 4/1) mud and diamict. They account for $>95 \%$ of core recovered. Photographs of some of the most common facies are shown in Figure F7. Based on characteristic facies associations, two lithostratigraphic units were defined (Table T3).

\section{Facies description}

Fourteen lithofacies were identified and are outlined in Table T2. Most of these are included within the collection of facies observed at other Expedition 341 sites. The numbering of the facies is based on facies documented for all Expedition 341 sites, but only facies documented at Site U1419 are described and discussed here. They include massive mud with lonestones (F1a), massive mud without lonestones (F1b), silt (F2a), interbedded or interlaminated silt and mud (F2b), very fine to coarse sand (F3a), interbedded sand and mud (F3c), interbedded mud and diamict (F4d), clast-poor diamict (F4e), clast-rich diamict (F4f), diatom ooze (F5a), biosiliceous ooze and 
biosiliceous rich/bearing mud (F5b), calcareous/carbonate-bearing mud (F5c), volcanic ash (F6), and volcaniclastic mud and sand (F7). The greater range in clast abundance within diamicts at this site allowed for differentiation of two subclasses of diamicts (clast-rich and clast poor; see Fig. F6 in the "Methods" chapter [Jaeger et al., 2014a]). These facies reflect deposition from suspension fall out, sediment gravity flows, ice rafting, variations in marine productivity, and volcanic eruptions.

The massive and bioturbated mud with lonestones of Facies F1a is mostly dark gray (N 4) to dark greenish gray (10Y 4/1), and bed thickness ranges from 3 to $1082 \mathrm{~cm}$ (Table T2; Fig. F7B). Bioturbation is generally absent or, in some cases, slight to moderate. A diagnostic characteristic of Facies F1a is the absence or low abundance of microfossils. Based on smear slides, the composition of the mud is, on average, $70 \%-80 \%$ clay-size particles and $20 \%-30 \%$ silt particles. Minor amounts $(<2 \%)$ of volcanic glass were documented in this facies based on smear slide observations. Lonestones consist mainly of argillite, siltstone, and metasiltstone with subordinate amounts of granitoid and sandstone and minor amounts of basalt (greenstone) and gabbro (Figs. F7B, F8A-F8F). Facies F1b is identical to Facies F1a, except for the absence of lonestones (Table T2; Fig. F7A), and ranges in thickness up to $432 \mathrm{~cm}$. In both facies, occasional foraminifers were recorded on smear slides.

Facies F2a consists of thin beds of dark gray (N 4) to very dark gray (N 3) silt that are irregularly spaced within the mud of Facies F1a and F1b (Table T2). The silt laminae/beds have sharp lower contacts and gradational upper contacts. Individual lamina/bed thickness ranges from 0.2 to $5 \mathrm{~cm}$ and often exhibits normal grading; packages of this facies are as thick as $257 \mathrm{~cm}$. Facies $2 \mathrm{a}$ is well sorted. The framework grain composition of this facies is almost entirely quartz and feldspar, with few lithic grains identified in smear slides. Accessory framework grains include biotite, hornblende, and heavy minerals. Lonestones are uncommon in this facies but may occur with as many as 30 lonestones per meter. Lonestone lithologies are similar to those described for Facies F1a.

Facies F2b consists of very dark to dark gray ( $\mathrm{N} 3$ and $\mathrm{N} 4$ ) to dark greenish gray (10Y 4/1) interbedded/interlaminated silt and mud (Table T2; Fig. F7C). Bed thickness for Facies F2b ranges from 8 to $392 \mathrm{~cm}$. Most commonly the beds contain $<40$ silt laminae per meter described, but in Section 341-U1419A$10 \mathrm{H}-3$, as many as 80 laminae per meter are documented. Lower contacts of silt laminae/beds are mostly sharp, whereas upper contacts are sharp or gradational. Bioturbation is absent to moderate, and lonestones are present in low abundance.

Facies F3a consists predominantly of gray (5Y 5/1) to dark gray (N 4) and dark greenish gray (10Y 4/1) very fine to coarse sand (Table T2; Fig. F7D). This facies often has a sharp lower contact and a gradational upper contact. Bed thickness commonly ranges from 1 to $8 \mathrm{~cm}$ but was observed up to $67 \mathrm{~cm}$. The sand has a muddy matrix, is poorly sorted, and sometimes contains minor amounts $(<10 \%)$ of foraminifers. A few of the sand beds contain $10 \%-30 \%$ foraminifers and are described as foraminifer-bearing sand. The sand framework grains are mainly quartz and feldspar, similar to the coarse silt composition of Facies F2a. Accessory minerals include biotite, hornblende, and zircon. Heavy minerals are generally present but are a minor constituent of Facies F3a.

Interbedded sand and mud define Facies F3c (Table T2). This facies is between 4 and $193 \mathrm{~cm}$ thick. Graded sand beds are as thick as $3.5 \mathrm{~cm}$ and have sharp lower boundaries and sharp upper boundaries. Their spacing is generally $<5 \mathrm{~cm}$. Lonestones $(<1 \mathrm{~cm})$ are occasionally present. Bioturbation is mostly absent in this facies.

Facies F4d consists of dark gray (N 4) interbedded mud and muddy diamict with bed thickness between 53 and $348 \mathrm{~cm}$ (Table T2). Individual diamict laminae/bed thickness varies from submillimeter scale to $12 \mathrm{~cm}$. Thicker diamict beds often have gradational lower and sharp upper boundaries. Clasts within the diamict are up to $5 \mathrm{~cm}$ in diameter and include siltstone, granitoid, quartz, greenstone, sandstone, and metasiltstone. Diatoms are occasionally present, and visual evidence for bioturbation is absent. Facies F4e is a dark gray (N 4) to very dark gray (N 3, 5 Y 3/1) clast-poor diamict with a muddy matrix (Fig. F7E). Bed thickness ranges from 20 to $300 \mathrm{~cm}$. Common clast sizes are granule and pebble, with clasts being subangular to subrounded. Dominant clast lithologies are argillite, siltstone, metasiltstone, granitoid, sandstone, basalt (greenstone), gabbro, chert, and rhyolite (Fig. F8A-F8F). Based on smear slides, the composition of the sand fraction is primarily quartzofeldspathic and the mud fraction is typically $35 \%$ silt and $65 \%$ clay-size particles. Facies F4f is a dark gray (N 4) to very dark gray (N 3) clastrich diamict, typically with a muddy matrix (Table T2; Fig. F7F). However, examples of sandy matrix were also documented. Intervals of this facies range in thickness from 10 to $716 \mathrm{~cm}$. Common clast sizes and their lithologies are similar to those described for Facies F4e.

Facies F5a is composed of mostly dark greenish gray (10Y 4/1), greenish gray (10Y 5/1), or olive-gray (5Y 
4/2) diatom ooze (Table T2; Fig. F7G). At Site U1419, intervals of ooze contain, on average, $80 \%$ diatoms, $10 \%$ silt, and $10 \%$ clay based on smear slides, as well as other minor fossil constituents. Contacts vary between gradational and sharp. The distinction between Facies F5a and F1a or F1b can be very subtle and only recognizable by the documentation of diatom abundance in smear slides. Some examples of Facies F5a also contain minor amounts of foraminifers. Intervals of Facies F5a vary in thickness from 3 to $600 \mathrm{~cm}$. Bioturbation is mostly absent but occasionally slight to heavy, and black mottling is common. Lonestones are rare in Facies F5a, except for in Core 341-U1419C-12H.

The biosiliceous ooze and biosiliceous-rich/bearing sediments of Facies F5b are similar to the characteristics described for Facies F5a, except that the biogenic material consists of a combination of diatoms, sponge spicules, and radiolarians and/or the amounts of diatoms are lower than required to be classified as diatom ooze (Table T2). Facies thickness ranges from 11 to $318 \mathrm{~cm}$. Occasionally a few foraminifers were also documented in this facies.

Facies F5c contains mostly dark greenish gray (10Y 4/1) calcareous/carbonate-bearing mud and sand (Table T2). Thickness ranges from 3 to $150 \mathrm{~cm}$.

Facies F6 is defined by gray (5Y 4/1) volcanic ash (Table T2; Fig. F7H). Bed thickness ranges from 2 to 4 $\mathrm{cm}$. Bed contacts are sharp to gradational. Compositionally, this facies consists of $90 \%$ glass shards (vitric fragments). The remaining framework grains are feldspar, quartz, and opaque minerals.

Predominantly dark gray ( $\mathrm{N} 4)$ and dark greenish gray (10Y 4/1) volcaniclastic mud, silt, diamict, and diatom microfossils define Facies F7 (Table T2). Bed thickness commonly ranges from 2 to $529 \mathrm{~cm}$. These beds consist of a mixture of volcanic glass (typically $10 \%-20 \%)$, silt-sized quartz and feldspar, and often diatom microfossils. One feature of the volcaniclastic beds at Site U1419 was the consistent presence of both brown and clear vitric shards. In contrast, volcaniclastic beds at Sites U1417 and U1418 were dominated by clear vitric shards. Lonestones occur but are not common in Facies F7. Bioturbation is mostly absent.

\section{Lithostratigraphic units}

Based on facies associations, two lithostratigraphic units were defined (Table T3). The contacts between lithostratigraphic units at Site U1419 are usually gradational, and the criteria used to define units are discussed below.

\section{Unit I}

Intervals: $341-\mathrm{U} 1419 \mathrm{~A}-1 \mathrm{H}-1,0 \mathrm{~cm}$, to $23 \mathrm{X}-1,0 \mathrm{~cm}$; $341-\mathrm{U} 1419 \mathrm{~B}-1 \mathrm{H}-1,0 \mathrm{~cm}$, to $14 \mathrm{H}-1,0 \mathrm{~cm} ; 341-$ U1419C-2H-1, $0 \mathrm{~cm}$, to $14 \mathrm{H}-1,24 \mathrm{~cm} ; 341-$ U1419D-2H-1, $0 \mathrm{~cm}$, to $17 \mathrm{H}-1,0 \mathrm{~cm} ; 341-$ U1419E-2H-1, $0 \mathrm{~cm}$, to $17 \mathrm{H}-3,60 \mathrm{~cm}$

Depths: U1419A $=0-138.0 \mathrm{~m}$ core depth below seafloor (CSF-A); U1419B = 0-95.5 m CSF-A; $\mathrm{U} 1419 \mathrm{C}=2.0-88.3 \mathrm{~m}$ CSF-A; U1419D $=5.5-$ 89.5 m CSF-A; U1419E = 9.0-91.2 m CSF-A

Age: Late Pleistocene to Holocene

Olive-gray (5Y 4/2) to dark greenish gray (10Y 4/1) diatom ooze extends from 0 to $5 \mathrm{~m}$ core composite depth below seafloor (CCSF-B) at this site (Fig. F9). Other thinner intervals of ooze (20-50 cm thick) and diatom-rich mud are spaced throughout Unit I. Dark gray (N 4) to dark greenish gray (10Y 4/1) mud with lonestones is the major lithology occurring deeper than $5 \mathrm{~m}$ CCSF-B. An interval of clast-rich diamict from 68 to $74 \mathrm{~m}$ CCSF-B in Holes U1419B and U1419E corresponds on the CCSF-B scale to mud with abundant clasts in Holes U1419A, U1419C, and U1419D. In Hole U1419A, clast content increases at depths deeper than $~ 90$ m CCSF-B, forming intervals of mud with abundant clasts. This depth is the transition between Units I and II, and it correlates with the transition to diamict described in Holes U1419BU1419E (Fig. F9).

Hole-to-hole variability in lithologic description in terms of the relative abundance of clasts/lonestones is explained by biases associated with the appearance of the core surface after splitting with a wire versus a saw blade. The wire tended to drag the mud across the split-core surface, obscuring the clasts and resulting in an emphasis on mud grain sizes in the visual core descriptions. Cutting with a saw allowed the identification of sedimentary structures, clast distribution, and clast composition at much greater detail. However, intervals of low-density, diatom-rich mud and ooze often were disturbed by the water introduced during sawing.

Clast composition is diverse and includes argillite, siltstone, sandstone, and granitoid. Subordinate lithologies include dark gray (N 4) interbedded sand and mud, thin $(\leq 1 \mathrm{~cm})$ sand beds with sharp lower contacts, and interbedded silt and mud. Shell fragments and an articulated bivalve are present in Unit I (Fig. F8G). One bed of volcanic ash was identified across Holes U1419B-U1419D at $~ 41 \mathrm{~m}$ CSF-A (Figs. F6B, F6C, F6D, F9). Another volcanic ash bed was identified in Hole U1419E at 24 m CSF-A (Figs. F6E, F9). In addition, numerous intervals of volcaniclasticbearing sediment are present within this unit. 


\section{Unit II}

Intervals: 341-U1419A-23X-1, $0 \mathrm{~cm}$, to 29X-CC, 18 $\mathrm{cm} ; 341-\mathrm{U} 1419 \mathrm{~B}-14 \mathrm{H}-1,0 \mathrm{~cm}$, to $19 \mathrm{H}-\mathrm{CC}, 26$ $\mathrm{cm}$; 341-U1419C-14H-1, $24 \mathrm{~cm}$, to $20 \mathrm{H}-\mathrm{CC}, 27$ $\mathrm{cm} ; 341-\mathrm{U} 1419 \mathrm{D}-17 \mathrm{H}-1,0 \mathrm{~cm}$, to $24 \mathrm{H}-\mathrm{CC}, 45$ $\mathrm{cm} ; 341-\mathrm{U} 1419 \mathrm{E}-17 \mathrm{H}-3,60 \mathrm{~cm}$, to $19 \mathrm{H}-\mathrm{CC}, 30$ $\mathrm{cm}$

Depths: Hole U1419A $=$ 138.0-189.7 m CSF-A; Hole U1419B $=95.5-114.0 \mathrm{~m}$ CSF-A; Hole $\mathrm{U} 1419 \mathrm{C}=88.3-108.6 \mathrm{~m}$ CSF-A; Hole U1419D = 89.5-114.1 m CSF-A; Hole U1419E = 91.2-98.9 m CSF-A

Age: Late Pleistocene

Dark gray (N 4) muddy clast-poor diamict is interbedded with dark gray ( $\mathrm{N} 4)$ laminated mud and thin coarse sand beds. Diamict beds contain subrounded to subangular granule- to pebble-sized clasts. The clasts have diverse lithologies including siltstone, sandstone, argillite, quartz, greenstone, granitoid, and diorite. Two intervals of diatom ooze occur between 100 and $104 \mathrm{~m}$ CCSF-B. One biosiliceous ooze interval occurs at $\sim 170 \mathrm{~m}$ CCSF-B. Detailed description of Unit II is limited by incomplete recovery deeper than $114 \mathrm{~m}$ CCSF-B, and this is reflected in the site summary diagram (Fig. F9).

\section{Petrography}

\section{Clast lithologies}

The main lithologies of the diamict clasts and lonestones contained in Site U1419 sediment (Fig. F8AF8F) are, in order of decreasing abundance, siltstone, argillite, sandstone, basalt, granitoid, and chert. The granitoid group includes intermediate and felsic rocks. Metasiltstone, graywacke, rhyolite, quartzite, and gneiss represent minor lithologies. These lithologies are relatively evenly distributed in Holes U1419A-U1419E. Averages for each hole and the site, according to the main lithology types metamorphic (M), igneous (I), and sedimentary (S) (Fig. F10), reveal the slight predominance of sedimentary lithologies over metamorphic and igneous ones. The average clast ratio for Site $\mathrm{U} 1419$ is $\mathrm{M}_{25} \mathrm{I}_{30} \mathrm{~S}_{45}$.

\section{Bulk mineralogy}

X-ray diffraction analyses were performed on 17 powdered bulk samples from Hole U1419A to delineate the bulk mineralogy and identify compositional trends with age and/or depth in the cores. The resulting diffraction patterns are shown in Figure F11, and the relative mineral diffraction peak intensities, as defined in "Lithostratigraphy" in the "Methods" chapter (Jaeger et al., 2014a), are listed in Table T4. In general, the bulk mineralogy is uniform downhole, although there are some variations in relative peak intensities, which may indicate slight variations in mineral content. Figure F11A shows the scans for all samples at this site. The primary minerals identified include quartz, plagioclase (feldspar), mica (muscovite/illite and biotite), and chlorite and/ or kaolinite. Quartz and plagioclase are the dominant peaks, with quartz generally larger. Figure F11B shows the comparative X-ray diffraction patterns from $4^{\circ}$ to $24^{\circ} 2 \theta$, where scans were run before and after the samples had undergone glycolization treatment (see "Lithostratigraphy" in the "Methods" chapter for details [Jaeger et al., 2014a]). This treatment was used to determine the presence of expandable clay minerals (e.g., smectite). The scans suggest evidence for the presence of expandable clay minerals deeper than $\sim 50 \mathrm{~m}$ CCSF-B. Our preliminary findings are similar to the results of Molnia and Hein (1982) from modern samples collected on the continental shelf of the Gulf of Alaska.

\section{Lithostratigraphy and depositional interpretations}

The distribution of primary sedimentary lithologies and clast abundance at Site U1419 is summarized in Figure F9. Lithostratigraphic Unit I (0-90 m CCSF-B) is primarily characterized by alternation between mud with varying concentration of clasts (dispersed, common, and abundant) and biosiliceous mud and diatom-rich mud. The upper $80 \mathrm{~m}$ of this unit also exhibit intermittent layers of sand. A $\sim 5 \mathrm{~m}$ thick diatom ooze is found at the very top of the recovered sedimentary sequence, and lonestones are notably absent from this interval. Isolated beds of diatomrich mud (12-50 cm thick) and a single diatom ooze are found in the upper $70 \mathrm{~m}$ CCSF-B of Unit I (Fig. F9). Where counted, the number of clasts $>2 \mathrm{~mm}$ per described meter fluctuates repeatedly but largely remains below 30 in Unit I. A prominent interval of interbedded mud and silt is found between 54 and 70 $\mathrm{m}$ CCSF-B, which is underlain by a $10 \mathrm{~m}$ thick interval containing diamict and mud with common and abundant clasts. In addition, multiple diatom oozes and intervals of diatom-rich mud are observed between 70 and $90 \mathrm{~m}$ CCSF-B. Counting of clasts was terminated in cores deeper than $70 \mathrm{~m}$ CCSF-B because of high concentrations and replaced with clastrich or clast-poor diamict (Fig. F9). However, the biogenic interval between 80 and 90 m CCSF-B contained sporadic clasts.

The transition from Unit I to Unit II (at 90 m CCSFB) is defined by the relatively rapid shift from biogenic sediments to the alternation of clast-poor and clast-rich diamict with intervals of mud with common and abundant clasts (Fig. F9). Two intervals of diatom ooze have been identified between 100 and 
105 m CCSF-B, but the Unit II sedimentary sequence is largely dominated by poorly sorted mud (with and without lonestones) and diamict. Core recovery averages $18 \%$ deeper than $118 \mathrm{~m}$ CCSF-B, and recovered sediments largely consist of clast-rich and clastpoor diamict. However, a $\sim 25 \mathrm{~cm}$ thick diatom ooze was observed at $~ 170 \mathrm{~m} \mathrm{CCSF-B.}$

\section{Unit I}

Lithostratigraphic Unit I consists mainly of dark gray (N 4) mud with lonestones (Fig. F7B). We interpret most of the mud as having originated from suspension settling from turbid meltwater plumes. The lonestones in Unit I are interpreted to have been rafted by icebergs calved from tidewater glaciers (Davies et al., 2011; Powell and Molnia, 1989). Diamict was deposited when icebergs contributed large quantities of debris greater than sand size to this site and/ or when the flux of mud was reduced relative to icerafted debris, thus increasing the proportion of coarse sediment (Davies et al., 2011) (Fig. F7F).

Sediment gravity flows are inferred from the presence of sand beds and intervals with interbedded sand and mud. These sand beds typically have sharp lower contacts and are normally graded (Fig. F7D). Other thin sand beds have less definite contacts and may be deposited from turbid meltwater plumes and/or sea ice.

The diatom-rich intervals in Unit I might be related to one or several processes:

- Increased biological productivity due to optimized oceanographic conditions (e.g., reduced sea ice cover or surface layer overturning and/or mixing by gyres; Addison et al., 2012);

- Enhanced macro (N, P) and/or micro (Fe) nutrient supply from land (through volcanic ash, dust, etc.) leading to increased biological productivity (Davies et al., 2011; Addison et al., 2012; Hamme et al., 2010);

- Increased biological productivity in the water column in the vicinity of sea ice margins (Sakshaug, 2004; Smith et al., 1987);

- Seawater silica saturation, leading to higher diatom productivity and better preservation (e.g., Brzezinski et al., 1998; Dugdale et al., 1995); and/ or

- Decreased input of terrigenous sediment (i.e., less dilution).

The alternation of diatom ooze and diatom-rich sediments with intervals dominated by iceberg or sea ice-transported sediment (mud with lonestones and diamict) is interpreted as reflecting climatic changes (Davies et al., 2011).
The sources for lonestones documented in Unit I are interpreted to be the onshore St. Elias Mountains and Chugach Mountains located along the southern coast of Alaska. Metasedimentary lithologies, common in the lonestones, occur in all of these ranges (Plafker, 1987; Plafker et al., 1994; Gasser et al., 2011). Felsic igneous clasts may be derived from the Sanak-Baranoff plutons found dispersed along the southern Alaska margin (Sisson et al., 2003). The thick mud deposits documented in the cores may also reflect supply from the nearby St. Elias orogen that includes fold-and-thrust belts onshore and on the adjacent shelf north of Site U1419 (Worthington et al., 2008; Pavlis et al., 2012). The quartzofeldspathic sand beds are interpreted as potentially being derived by recycling of metasedimentary and sedimentary strata in the accretionary prism complex of the Chugach Range and the Neogene thrust belt of the Yakutat terrane (Plafker et al., 1994). Similar sandstone in the onshore part of the Yakataga Formation of the Yakutat terrane contains detrital zircon populations indicative of reworking from metasedimentary and sedimentary strata exposed in nearby thrust sheets (Perry et al. 2009; Witmer, 2009).

The rare volcanic ash and volcaniclastic-bearing sand at Site U1419 indicates that the location was proximal enough to either the Aleutian or Wrangell volcanic belts to have periodic influxes of pyroclastic detritus. The mixing of volcanic ash with other sediment types, common at Site U1419, likely resulted from the high sediment flux from other processes relative to the influx of ash at this site. The common occurrence of brown vitric shards at this site compared to Sites U1417 and U1418 may be a function of the proximity of Site U1419 to the Wrangell volcanic field rather than the Aleutian volcanic belt.

\section{Unit II}

Diamict Facies F4e and F4f within Unit II are interpreted as having a glacigenic origin. The observation of gradational contacts between facies of clast-rich diamict interstratified with mud (including mud with diatoms) likely indicates a fluctuating sediment supply typical of a glacimarine environment. Massive diamict beds in this unit appear to indicate periods of more intense iceberg rafting with a high flux of sand and coarser sediment. Intervals of interbedded mud and thin diamict beds suggest the possibility of sea ice rafting over Site U1419 in addition to iceberg rafting (Cowan et al., 1999).

Sediment gravity flows are indicated by interbedded sand and mud and thicker sand beds. Some of the diamict intervals may have been deposited by debris flows, but this potential transport mechanism re- 
quires postcruise study. Two intervals of diatom/biosiliceous ooze are interbedded with diamict in Unit II, suggesting that episodes of higher productivity and/or reduced glacial sediment supply also occurred.

\section{Paleontology and biostratigraphy}

Microfossil abundance and preservation at Site U1419 varies depending on skeletal composition. Calcareous microfossils (planktonic and benthic foraminifers) are well preserved and continuously abundant at Site U1419. Siliceous microfossil preservation and abundance are less consistent. Radiolarian faunas are moderately preserved in the upper $\sim 100 \mathrm{~m}$ CCSF-B, and their abundances fluctuate from rare to abundant. Deeper than $100 \mathrm{~m}$ CCSF-B, almost all samples are barren of radiolarians. The diatom preservation and abundance trends are similar to the radiolarian trends; however, diatoms are less well preserved, and their abundance is lower shallower than $100 \mathrm{~m}$ CCSF-B. From $\sim 80$ to $90 \mathrm{~m}$ CCSF-B, diatom resting spores have an abundance peak, and the benthic foraminifer Eubuliminella exilis dominates the benthic foraminifer assemblage, suggesting a notable environmental change in the water column and at the seafloor during the time represented by that interval.

\section{Diatoms}

In order to define the sediment depositional age and paleoenvironmental conditions, core catcher samples and samples from selected split core sections from Holes U1419A-U1419E were investigated (Table T5; Fig. F12). Approximately two samples per core were analyzed in Holes U1419A-U1419E; however, 71 of the 149 samples investigated are barren of diatoms. Most of the barren samples are deeper than $113 \mathrm{~m}$ CCSF-B. Diatom occurrence and valve preservation vary strongly throughout the sediment column of Site U1419.

The only biozone recognized at Site U1419 is Zone NPD 12 (present-[0.3 \pm 0.1$] \mathrm{Ma}$ ) because we did not observe the last occurrence (LO) of Proboscia curvirostris (Jousé) Jordan et Priddle (D120; $0.3 \pm 0.1 \mathrm{Ma}$ ). Thus, we consider all of the retrieved sediment to be within Zone NPD 12. For a detailed description of diatom zonal scheme and taxonomy, see the "Methods" chapter (Jaeger et al., 2014a).

Diatom assemblages at Site U1419 are generally dominated by coastal and neritic species, mainly Thalassionema nitzschioides (Grunow) Mereschkow- sky, Paralia sulcata (Ehrenberg) Cleve, and resting spores of Chaetoceros (Fig. F13). Although Chaetoceros resting spores are present throughout the cores, they are especially abundant in the interval from 75 to 90 m CCSF-B. High relative abundances of Chaetoceros resting spores are treated as indicative of high-productivity continental shelf and margin environments (e.g., Sancetta, 1982; Suto et al., 2012). The co-occurrence of other coastal and neritic species with Chaetoceros resting spores could also imply offshore transport.

Cold-water species, defined following Hasle and Syvertsen (1996) and Koizumi (2008), are also dominant at Site U1419 and show particularly high abundances in the uppermost $10 \mathrm{~m}$ CCSF-B and in the interval from 75 to $90 \mathrm{~m}$ CCSF-B (Fig. F13). Sea icerelated warm and temperate species are also continuously present downcore; however, these species are not a significant component of the assemblage and range between present and rare.

\section{Radiolarians}

Radiolarians are well preserved in the upper $110 \mathrm{~m}$ CCSF-B, and their abundances fluctuate between rare to abundant. However, deeper than 110 m CCSF-B, almost all samples are barren (Fig. F12). Based on observations of 43 species, all samples from Site U1419 are located inside the Botryostrobus acquilonaris Zone $(0-0.5 \mathrm{Ma})$. The LO datum of Stylocontharium acquilonium Hays (0.4 Ma) is not encountered, suggesting that the sediments are younger than 0.4 Ma. The occurrence of Lychnocanoma sakaii is not continuous, and therefore it is difficult to precisely define the LO of this species $(0.03 \mathrm{Ma})$. The last observed occurrence of L. sakaii is between Samples 341-U1419D16H-CC (87.98 m CCSF-B) and 341-U1419B-12H-CC (88.45 m CCSF-B). However, based on the sporadic occurrence of $L$. sakaii, the sediment between those two intervals may be older than $30 \mathrm{ka}$ (Table T6).

Generally, cold-water taxa dominate the assemblages (Fig. F13). This group of environmentally sensitive taxa is composed of Stylochlamydium venustum Bailey and Stylodictya vallisdispina Jørgensen following Kamikuri et al. (2008). Cold-water taxa are abundant almost continuously as deep as 110 m CCSF-B. Warmwater taxa fluctuate from barren to common in the upper $110 \mathrm{~m}$ CCSF-B.

\section{Foraminifers}

Core catcher samples from Hole U1419A were examined for planktonic foraminifers from the $>125 \mu \mathrm{m}$ size fraction in 26 samples (Table T7) and for benthic foraminifers from the $>63 \mu \mathrm{m}$ size fraction in 26 samples (Table T8). 


\section{Planktonic foraminifers}

Planktonic foraminifers are present in all examined samples except for Sample 341-U1419A-19H-CC (118.53 m CCSF-B). Their abundances range from present to abundant, and their preservation ranges from very good to moderate (Fig. F12). Fourteen planktonic foraminifer species are encountered at Site U1419; faunal assemblages are dominated by polar to subpolar species Neogloboquadrina pachyderma (sinistral) and subtropical to temperate species Globigerina bulloides and Globigerina umbilicata (Table T7; Fig. F14). N. pachyderma (dextral) is also present at this site; abundances range from rare to present. The extinct species Neogloboquadrina kagaensis (LO $1.9 \pm 0.02 \mathrm{Ma}$ ) is present in Samples 341-U1419A$16 \mathrm{H}-\mathrm{CC}$ and $26 \mathrm{H}-\mathrm{CC}$, suggestive of occasional input of reworked sediment.

At Site U1419, the total group abundance of planktonic foraminifers shows recurring changes downhole (Figs. F12, F14), which coincide with changes in the faunal assemblage. High abundances of planktonic foraminifers occur between the intervals of 6.30-13.37 m CCSF-B (Samples 341-U1419A-1H-CC to 2H-CC) and 80.44-94.36 m CCSF-B (Samples 10H$\mathrm{CC}$ to $12 \mathrm{H}-\mathrm{CC})$. Concurrently, the relative abundances of $G$. umbilicata and G. bulloides decrease from abundant to few between 80.44 and $94.36 \mathrm{~m}$ CCSF-B. The concurrent changes in group abundance and in planktonic foraminifer faunal composition suggest that upper ocean conditions changed during the deposition of that sediment interval, but further study is necessary to confirm this hypothesis.

\section{Benthic foraminifers}

All core catchers examined contained benthic foraminifers (Fig. F12). Abundances were highest from $\sim 80.46$ to $94.34 \mathrm{~m}$ CCSF-B and lowest between 118.53 and $149.58 \mathrm{~m}$ CCSF-B. Preservation was generally moderate to very good, with poor preservation deeper than $178 \mathrm{~m}$ CCSF-B. Thirty-six species or species groups were identified (Table T8). The number of genera per sample ranges from 4 to 17 .

The taxonomic composition of benthic foraminiferal samples varies downhole (Table T7; Fig. F15). Shallower than 100 m CCSF-B, samples commonly contain abundant to dominant Epistominella pacifica and/or Uvigerina akitaensis and rare to dominant $E$. exilis. Deeper than $100 \mathrm{~m}$ CCSF-B, samples more frequently contain abundant to dominant Elphidium spp. This change in taxonomic composition roughly corresponds to the transition between lithostratigraphic Units I and II ( 90 m CCSF-B; Fig. F15), suggesting that increased productivity (Unit I is richer in biosiliceous muds), a decline in the input of coarse sediment (Unit II is richer in clasts), and/or a change in a correlated environmental factor contributed to the faunal change. Shallow-water Elphidium species may also have been more frequently transported to the site during the deposition of Unit II. Species that frequently occur at abundances from few to dominant throughout the record include Cassidulina cushmani and Islandiella norcrossi; Nonionella labradorica is also a major constituent, with abundance fluctuations from rare to abundant (Fig. F15).

E. exilis is dominant in Samples 341-U1419A-10HCC $(\sim 80.46 \mathrm{~m}$ CCSF-B) and 11H-CC $(\sim 86.52 \mathrm{~m}$ CCSF-B), where preservation is also at its highest (Figs. F12, F15). This species may indicate low-oxygen conditions or high export of organic carbon to the seafloor. These samples contain a very low sand fraction compared to rest of the samples, and this faunal change could also be related to processes that influence the sedimentary grain size.

\section{Calcareous nannofossils}

Calcareous nannofossil abundances in Hole U1419A range from barren to common and are poorly to well preserved. Nannofossil abundance is greatest shallower than $25 \mathrm{~m}$ CCSF-B in the hole, with the exception of $0-5 \mathrm{~m}$ CCSF-B, where the core is almost barren of nannofossils. Nannofossil abundance gradually decreases from 25 to $80 \mathrm{~m}$ CCSF-B, from few to barren. From 80 to $100 \mathrm{~m}$ CCSF-B, nannofossils are rare to few, and deeper than $100 \mathrm{~m}$ CCSF-B, nannofossils are very rare. The most common species observed are Coccolithus pelagicus, Cruciplacolithus neohelis, Gephyrocapsa oceanica, reticulofenestrids, and Braarudosphaera spp.

\section{Stratigraphic correlation}

The composite depth scale at Site U1419 is constructed from 0.0 to $205.79 \mathrm{~m}$ core composite depth below seafloor (CCSF-A). The splice consists of one complete and continuous interval from the mudline to $112.10 \mathrm{~m}$ core composite depth below seafloor (CCSF-D). The CCSF-A and CCSF-D depth scales are defined in "Stratigraphic correlation" in the "Methods" chapter (Jaeger et al., 2014a).

The splice ranges from the top of Core 341-U1419B$1 \mathrm{H}$ (the mudline) to the base of Core 341-U1419E17H (Tables T9, T10). To the extent possible, the splice was constructed from Holes U1419D and U1419E (six intervals each), although five intervals were included from Hole U1419B and two were included from Hole U1419C. Hole U1419A was avoided in the splice when possible because it was sampled at sea; nevertheless, it was necessary to include two short intervals of Hole U1419A in the splice. 
Weather was calm and ship heave was negligible while coring Site U1419, but the sediments were relatively rich in lonestones, as expected for an iceproximal environment. This lithology proved challenging for core recovery and interhole correlation. Intervals of core disturbance, incomplete recovery, and use of the half APC coring system all presented complications in the development of composite depths and a spliced record. In particular, we observed many instances of flow-in, generally (but not always) near the base of cores, and some fall-in of rocky debris in core tops. Some parts of the splice are unique in an individual hole and are not well verified.

Correlations between holes were accomplished using the Integrated Ocean Drilling Program Correlator software (version 1.695), and all the splice tie points were checked with digital line-scan images using Corelyzer (version 2.0.2), linked to Correlator. During coring, real-time development of composite depths and guidance for coring operations relied on Special Task Multisensor Logger (STMSL) gamma ray attenuation (GRA) bulk density and magnetic susceptibility (MS) data. The final composite depth scale (CCSF-A) and the splice (CCSF-D scale) are based primarily on the stratigraphic correlation of MS and GRA density from the Whole-Round Multisensor Logger (WRMSL) (Figs. F16, F17), as well as wholeround natural gamma radiation (NGR) from the Natural Gamma Ray Logger and reflectance spectroscopy color data from the Section Half Multisensor Logger (SHMSL). Of these variables, MS offered the most reliable tool for correlation at Site U1419; the other variables served primarily as verification data and were generally less useful for purposes of holeto-hole correlation. Anomalously low GRA density was used primarily as an indicator of core disturbance. MS from the loop sensors was checked with point MS data, although the presence of small lonestones in intervals of diamict made the point-sensor data relatively noisy.

The CCSF-A and CCSF-D scales were constructed by assuming that the uppermost sediment (the mudline) in Core 341-U1419B-1H represented the sediment/water interface. An approximate mudline was also recovered in Core 341-U1419A-1H, confirming the fidelity of the top of the recovered interval. Core 341-U1419B-1H serves as the "anchor" in the composite depth scale and is the only core with depths that are the same on the CCSF-A and CCSF-D scales. From this anchor we worked downhole, matching the variations in core logging data on a core-by-core basis using Correlator.

In the splice, one of the included intervals (341U1419D-9H-3, $51.2 \mathrm{~cm}$, to 9H-7, $69.2 \mathrm{~cm}$; 55.33-
60.06 m CCSF-A) contains possible disturbance from void collapse during core processing and archiving on the catwalk, but this appeared to be the least disturbed option for this interval of the splice. Several tie points are tentative. In particular, the tie point between 341-U1419C-6H-7, $102.7 \mathrm{~cm}$, and 341U1419D-9H-3, $51.2 \mathrm{~cm}$ (55.33 m CCSF-D), is weak because of probable coring disturbance at shallower depths in Sections 341-U1419D-9H-1 through 9H-3. The ties between 341-U1419D-9H-7, $69.2 \mathrm{~cm}$, and 341-U1419B-7H-1, $146.1 \mathrm{~cm}$ (60.06 m CCSF-D); 341U1419E-12H-5, $88.2 \mathrm{~cm}$, and 341-U1419A-9H-1, $83.7 \mathrm{~cm}$ (79.00 m CCSF-D); and 341-U1419B-9H-6, $135.1 \mathrm{~cm}$, and 341-U1419E-14H-1, $54.7 \mathrm{~cm}(89.34 \mathrm{~m}$ CCSF-D), all have very little overlap, which increases the probability of a temporal gap due to nonrecovery. The tie point between 341-U1419A-10H-6, 65.7 $\mathrm{cm}$, and 341-U1419E-15H-1, $26.2 \mathrm{~cm}$ (96.96 m CCSF-D), requires a splice to a relatively short core (although the variations in MS appear to be reproduced in Core 341-U1419B-10H). Similarly, the tie point between 341-U1419E-15H-3, $17.3 \mathrm{~cm}$, and 341-U1419C-12H-1, $51.9 \mathrm{~cm}$ (99.49 m CCSF-D), has very little overlap and leaves the chance of a temporal gap. It is possible that the interval from 96.96 to 99.49 m CCSF-D is a condensed replication of the interval from $\sim 100$ to $103.6 \mathrm{~m}$ CCSF-A; this part of the splice will need to be checked with postcruise data.

Within the splice, the composite CCSF-A depth scale is (by definition) identical to the CCSF-D depth scale. Note that CCSF-D rigorously applies only to the spliced interval. Intervals outside the splice, although available with CCSF-A composite depth assignments, should not be expected to correlate precisely with fine-scale details within the splice or with other holes because of variation in the relative spacing of features in the recovered intervals from different holes. Such apparent depth differences may reflect coring artifacts or fine-scale spatial variations in sediment accumulation and preservation at and below the seafloor.

The cumulative offset between the CSF-A depth scale and the CCSF-A and CCSF-D depth scales is nonlinear (Fig. F18). The affine growth factor (a measure of the fractional stretching of the composite section relative to the drilled interval; see "Stratigraphic correlation" in the "Methods" chapter [Jaeger et al., 2014a]) is 1.145 on average (i.e., the sediment is expanded by $\sim 15 \%$ relative to the interval drilled) at Site U1419 in the APC-cored interval from 0 to 72.52 $\mathrm{m}$ CCSF-A or CCSF-D. Anomalies around this relatively uniform affine growth relationship are plausibly explained by partial recovery in lonestone-rich sediments (implying uncertainty in what portion of the cored interval is represented by recovered sedi- 
ment) and uncertainty in the application of tide corrections for drilling depths (for example, between Cores 341-U1419A-1H and 2H).

Within the interval from 72.52 to $137.50 \mathrm{~m}$ CCSF-A, the affine growth factor is 1.279 (i.e., the sediment is expanded by $\sim 28 \%$ relative to the interval drilled). Such a high rate of expansion at Site U1419 likely reflects either coring artifacts in the borehole or gas expansion of sediments during recovery (see "Geochemistry" for discussion of methane at Site U1419). Below $137.50 \mathrm{~m}$ CCSF-A, intervals of possible correlation were found between a few cores, but the intervals were not considered sufficiently continuous nor were the correlations certain enough to warrant adjustment of their affine values on a coreby-core basis. In this interval, the affine value is held at a constant $28.66 \mathrm{~m}$. This does not imply that there is no sediment expansion at depths below $137.50 \mathrm{~m}$ CCSF-A, just that we have no constraint on its extent.

Calculation of mass accumulation rates based on the CCSF-A or CCSF-D scale must correct for the affine growth factor. To facilitate this process, we developed an additional depth model, CCSF-B, which compressed the CCSF-A and CCSF-D scales into a scale that has the same total depth of sediment column as the interval actually drilled (see "Stratigraphic correlation" in the "Methods" chapter [Jaeger et al., 2014a]). The following three equations define transformation of the CCSF-A or CCSF-D depth scale into CCSF-B depths (Fig. F18):

From 0 to $72.52 \mathrm{~m}$ CCSF-A/CCSF-D:

CCSF-B $=0.85503 \times$ CCSF-A/CCSF-D.

From 72.52 to 137.50 m CCSF-A/CCSF-D:

CCSF-B $=0.72068 \times$ CCSF-A/CCSF-D +9.743.

For 137.50 m CCSF-A/CCSF-D:

CCSF-B = CCSF-A/CCSF-D - 28.663.

The depth boundaries between these equations are chosen to coincide with a splice point (between 341U1419D-10H-6, $6.79 \mathrm{~cm}$, and 341-U1419E-12H-1, $40.83 \mathrm{~cm}$, at $72.52 \mathrm{~m}$ CCSF-A) and at the top of Core 341-U1419E-23H (137.50 m CCSF-A).

\section{Initial age model}

Normal geomagnetic polarity in all cores implies that all sediments recovered are younger than 781 $\mathrm{ka}$. The uppermost part of the sequence can be correlated with site survey Core EW0408-85JC, a radiocarbon-dated piston core from the same site (Davies et al., 2011), based on MS. The interval of relatively low MS from 0 to $6.4 \mathrm{~m}$ CCSF-A (0 to $5.5 \mathrm{~m} \mathrm{CCSF-B)} \mathrm{at}$ Site U1419 is assigned to Holocene and Late Pleistocene ages (0-15 ka), implying an average interglacial sedimentation rate of $0.4 \mathrm{~m} / \mathrm{k} . \mathrm{y}$. Oxygen isotopes of foraminifers picked at sea from the core catcher sample and analyzed immediately postcruise at Oregon State University (USA), indicate that the maximum age at the base of the site (205.79 m CCSF-A) is $<60,000 \mathrm{y}$, implying an average glacial sedimentation rate of $3.8 \mathrm{~m} / \mathrm{k} . \mathrm{y}$.

\section{Geochemistry Interstitial water chemistry}

Interstitial water (IW) samples were only taken in Hole U1419A. The following results are expressed on the CCSF-B depth scale for Site U1419 (see "Stratigraphic correlation").

In Hole U1419A, 22 IW samples were taken with a resolution of two samples per core in Cores 341$\mathrm{U} 1419 \mathrm{~A}-1 \mathrm{H}, 6 \mathrm{H}$, and $9 \mathrm{H}$; three samples per core in Cores $2 \mathrm{H}, 3 \mathrm{H}$, and $8 \mathrm{H}$; and one sample per core from Core $11 \mathrm{H}$ to the bottom of the hole. Whole rounds for IW analysis were $5 \mathrm{~cm}$ long in Cores 341U1419A-1H through $9 \mathrm{H}$ and $10 \mathrm{~cm}$ long in Cores $11 \mathrm{H}$ through 26X. Samples from Hole U1419A were collected from APC cores (0-115.2 m CCSF-B) and XCB cores (140.9-168.5 m CCSF-B), and the results below refer to the combined APC and XCB sample record. The applied squeezing pressures ranged from 8,000 to $32,000 \mathrm{psi}$, and the volumes of IW extracted range between 20 and $40 \mathrm{~mL}$. Splits of the IW samples were taken and processed following methods outlined in "Geochemistry" in the "Methods" chapter (Jaeger et al., 2014a) using shipboard analyses or were preserved for shore-based analysis of dissolved trace metals, oxygen/sulfur/calcium/strontium isotopes, dissolved inorganic carbon, and silica.

\section{Alkalinity, pH, chloride, and salinity}

Following a steep increase from the core top to 20.8 $\mathrm{m}$ CCSF-B, a broad alkalinity maximum occurs at Site U1419 from 23.4 to 70.4 m CCSF-B, with a maximum value of $37.1 \mathrm{mM}$ recorded at $59.8 \mathrm{~m}$ CCSF-B (Fig. F19A). From $85.6 \mathrm{~m}$ CCSF-B, alkalinity decreases downcore to $13.7 \mathrm{mM}$ by $140.9 \mathrm{~m}$ CCSF-B. The $\mathrm{pH}$ values range from 7.49 to 7.8 between 2.5 and $169.5 \mathrm{~m}$ CCSF-B without a systematic trend (Fig. F19B).

Chloride concentrations (titrated) decrease with depth from 550.2 to $446.5 \mathrm{mM}$ in the upper $140 \mathrm{~m}$ CCSF-B of Site U1419 (Fig. F19I). Salinity gradually decreases from 33 at the top of the core to 32 by 59.8 
$\mathrm{m}$ CCSF-B and then decreases more rapidly to a minimum of 25 at $140.9 \mathrm{~m}$ CCSF-B.

\section{Dissolved ammonium, phosphate, and silica}

Dissolved ammonium concentrations increase rapidly from $0.6 \mathrm{mM}$ at $2.5 \mathrm{~m}$ CCSF-B to $3.0 \mathrm{mM}$ at 20.8 $\mathrm{m}$ CCSF-B (Fig. F19D). They continue to increase more gradually downcore, reaching a maximum of $4.6 \mathrm{mM}$ at $70.4 \mathrm{~m} \mathrm{CCSF-B}$, and then decrease to 1.9 $\mathrm{mM}$ deeper than $140.9 \mathrm{~m}$ CCSF-B.

Phosphate concentrations range from 7.4 to $78.6 \mu \mathrm{M}$ at Site U1419 (Fig. F20J), with higher and more variable values in the uppermost 100 m CCSF-B (25.4$74.0 \mu \mathrm{M}$ ) followed by a decrease to $\leq 16 \mu \mathrm{M}$ to the bottom of the hole.

Silica concentrations at Site U1419 range from 602 to $843 \mu \mathrm{M}$ and generally increase downcore (Fig. F19G).

\section{Dissolved sulfate, calcium, magnesium, potassium, sodium, and bromide}

Sulfate concentrations at Site U1419 decrease sharply with depth from 2.5 to 12.6 m CCSF-B (from 20.7 to $2.2 \mathrm{mM}$ ), with $12.6 \mathrm{~m}$ CCSF-B defined as the depth of total sulfate depletion (Fig. F19C). Deeper than this depth, sulfate concentrations range between 0.9 and $1.3 \mathrm{mM}$.

Calcium concentrations at Site U1419 decrease sharply with depth from 2.5 to 12.6 m CCSF-B (from 8.4 to $3.2 \mathrm{mM}$ ) (Fig. F20A), stabilize around 3.7-4.0 $\mathrm{mM}$ between 40 and $85 \mathrm{~m}$ CCSF-B, reach a local minimum at $90.5 \mathrm{~m}$ CCSF-B $(3.1 \mathrm{mM})$, and increase to concentrations around $4.8 \mathrm{mM}$ deeper than 106 m CCSF-B.

Magnesium concentrations vary between 34.6 and $49.6 \mathrm{mM}$ at Site U1419 (Fig. F20C). They decrease sharply from 49.6 to $46.5 \mathrm{mM}$ between 2.5 and 12.6 $\mathrm{m}$ CCSF-B and stabilize at $\sim 47.5 \mathrm{mM}$ to $85.6 \mathrm{~m}$ CCSF-B. Deeper, magnesium concentrations decrease, reaching a minimum value of $34.6 \mathrm{mM}$ at $140.9 \mathrm{~m}$ CCSF-B, and remain at low concentrations to the bottom of the hole.

Potassium concentrations at Site U1419 decrease downcore from 10.6 to $8.4 \mathrm{mM}$ (2.5-62.4 m CCSF-B) (Fig. F20B). Below a local maximum $(8.5 \mathrm{mM})$ at $68.2 \mathrm{~m}$ CCSF-B, potassium concentrations decrease downcore to a minimum of $5.6 \mathrm{mM}$ at $168.5 \mathrm{~m}$ CCSF-B.

Sodium concentrations show an overall downcore decrease that steepens deeper than $68.0 \mathrm{~m}$ CCSF-B (Fig. F19J). The maximum sodium concentration of
$470 \mathrm{mM}$ occurs at $2.5 \mathrm{~m}$ CCSF-B, and the minimum concentration of $377 \mathrm{mM}$ is recorded at $140.9 \mathrm{~m}$ CCSF-B.

Bromide concentrations at Site U1419 increase downcore to reach a broad maximum of $\sim 0.98 \mathrm{mM}$ between 41.5 and $64.6 \mathrm{~m}$ CCSF-B (Fig. F19E). Deeper than $68.2 \mathrm{~m}$ CCSF-B, bromide concentrations decrease, reaching a minimum of $0.81 \mathrm{mM}$ at $140.9 \mathrm{~m}$ CCSF-B.

\section{Dissolved manganese, iron, barium, strontium, boron, and lithium}

Manganese concentrations at Site U1419 vary between 1.7 and $3.9 \mu \mathrm{M}$ in the upper $\sim 60 \mathrm{~m}$ CCSF-B (Fig. F20I). Manganese concentrations decrease to a minimum of $1.7 \mu \mathrm{M}$ at $70.4 \mathrm{~m}$ CCSF-B. Farther downcore, a progressive increase is recorded to the bottom of the hole.

Dissolved iron concentrations at Site U1419 generally vary between 0 and $3.6 \mu \mathrm{M}$, excluding three isolated maxima at 23.4, 59.8, and $90.4 \mathrm{~m}$ CCSF-B (Fig. F20H). Local minima occur around 42 and $115 \mathrm{~m}$ CCSF-B.

Barium concentrations are below detection limit at Site U1419 from the top of the core to 18.2 m CCSF$\mathrm{B}$, where barium concentrations increase rapidly to $11.9 \mu \mathrm{M}$ (Fig. F20F). Deeper than $68.2 \mathrm{~m}$ CCSF-B, a more gradual increase in barium occurs, including isolated barium maxima (e.g., $45.6 \mu \mathrm{M}$ at $115.2 \mathrm{~m}$ CCSF-B). Detectable barium concentrations are limited to the sediment interval with lowest sulfate concentrations.

Strontium concentrations decrease from 85 to $76 \mu \mathrm{M}$ between 2.5 and 12.6 m CCSF-B (Fig. F20G). Deeper than $12.6 \mathrm{~m}$ CCSF-B, strontium concentrations decrease gradually to $\sim 100 \mu \mathrm{M}$ at $90.4 \mathrm{~m}$ CCSF-B. Deeper than $97.6 \mathrm{~m}$ CCSF-B, strontium concentrations increase more rapidly, reaching values of $\sim 128$ $\mu \mathrm{M}$ deeper than $115 \mathrm{~m}$ CCSF-B.

Boron concentrations increase from $\sim 500 \mu \mathrm{M}$ at the top of the hole to a maximum of $\sim 600 \mu \mathrm{M}$ at $20.8 \mathrm{~m}$ CCSF-B. Deeper, boron concentrations decrease slightly to $85.6 \mathrm{~m}$ CCSF-B and then more rapidly to reach concentrations of $<300 \mu \mathrm{M}$ at the bottom of the hole.

Lithium concentrations at Site U1419 increase rapidly from $20.7 \mu \mathrm{M}$ at the core top to $23.6 \mu \mathrm{M}$ at 7.5 $\mathrm{m}$ CCSF-B (Fig. F20D). Deeper downcore, lithium decreases to $19.2 \mu \mathrm{M}$ at $12.6 \mathrm{~m}$ CCSF-B and then decreases more slowly from $13 \mathrm{~m}$ CCSF-B to the bottom of the hole. A local minimum of $8.6 \mu \mathrm{M}$ is recorded at $115.2 \mathrm{~m}$ CCSF-B. 


\section{Volatile hydrocarbons}

Headspace gas samples were collected at a resolution of one per core in Hole U1419A only (Cores 341U1419A-1H through 27X). Methane is the dominant hydrocarbon gas detected. Methane is in very low concentrations ( $<5 \mathrm{ppmv}$ ) in Cores 341-U1419A-1H and $2 \mathrm{H}$ but increases starting at Core $3 \mathrm{H}$ and in general ranges between 4,400 and 39,000 ppmv throughout Hole U1419A (Fig. F19F). Ethane is only intermittently present, and concentrations remain very low throughout Hole U1419A ( $<1 \mathrm{ppmv})$; the $\mathrm{C}_{1} / \mathrm{C}_{2}$ ratio is correspondingly high $(>40,000)$, indicating no threat to drilling operations.

\section{Bulk sediment geochemistry}

Discrete core samples were analyzed from Site U1419 for total carbon, total nitrogen (TN), and total inorganic carbon. From these analyses, total organic carbon (TOC) and calcium carbonate $\left(\mathrm{CaCO}_{3}\right)$ were calculated as described in "Geochemistry" in the "Methods" chapter (Jaeger et al., 2014a). In total, 20 samples were analyzed from Hole U1419A (Cores 341-U1419A-1H through 26X). Discrete samples were selected in collaboration with the Lithostratigraphy group to ensure that the primary lithologies were analyzed.

The TOC content at Site U1419 ranges between 0.4 and 1.0 wt $\%$ with no clear downcore trend (Fig. F21A). The highest TOC contents are recorded in lithologies with notable diatom content at $0.5 \mathrm{~m}$ CCSF-B (0.87 wt\%) and $60.7 \mathrm{~m} \mathrm{CCSF-B} \mathrm{(0.95} \mathrm{wt \% )} \mathrm{in}$ Cores 341-U1419A-1H and $8 \mathrm{H}$, respectively (see "Lithostratigraphy").

The TN content at Site U1419 ranges between 0 and $0.1 \mathrm{wt} \%$ and shows no downcore trend (Fig. F21B). Slightly elevated TN contents are observed in the two samples with high TOC contents, but values remain very low. Organic carbon to $\mathrm{TN}(\mathrm{C} / \mathrm{N})$ ratios range between 10 and 22 (Fig. F21C), consistent with a contribution from both marine and terrigenous organic matter (Hedges et al., 1986; Walinsky et al., 2009). The negative $y$-axis intercept in the correlation between TOC and TN (Fig. F21E) implies that organic $\mathrm{N}$ dominates the $\mathrm{TN}$ content. Determination of the contribution of inorganic $\mathrm{N}$ is required to fully assess the relative contributions of marine and terrigenous input to the organic matter at Site U1419.

$\mathrm{CaCO}_{3}$ contents range mostly between 1.5 and 4.0 wt $\%$ at Site U1419 (Fig. F21D). High $\mathrm{CaCO}_{3}$ content is recorded in a TOC-rich diatom ooze sample (60.7 m CCSF-B; Core 341-U1419A-8H) that also contains shell fragments (see "Lithostratigraphy") and in the sand lithology recorded in Core 341-U1419A-26X (167.5 m CCSF-B).

\section{Interpretation}

The IW and sediment composition at Site U1419 indicate relatively high rates of organic matter remineralization. Although TOC contents at Site U1419 are low $(<1 \mathrm{wt} \%)$, the high sedimentation rates imply that respective TOC accumulation rates are also high (see "Stratigraphic correlation"). The potentially high organic matter accumulation rates are likely reflected in the pronounced diagenetic processes occurring at Site U1419, discussed below. $\mathrm{CaCO}_{3}$ contents are also low but indicate a contribution of biogenic carbonate to the sediment composition, which is in agreement with high abundances and preservation of foraminifers at Site U1419 (see "Paleontology and biostratigraphy").

A distinct interval with low MS at $~ 80-90$ m CCSF-B (see "Lithostratigraphy") is not paralleled by a TOC maximum, as would be expected if both the magnetic and geochemical records were influenced by enhanced deposition of organic matter and the resulting diagenetic dissolution of magnetite. However, it is possible that the measured TOC contents only represent the refractory fraction of the originally deposited organic matter, so a connection between diagenetic processes and the magnetic properties cannot be excluded. Dissolution of biogenic opal and/or volcanic glass is indicated by dissolved silica concentrations that are higher than those of the overlying North Pacific Deep Water $(\sim 160 \mu \mathrm{M})$. There is high variability in the dissolved silica profile at Site U1419, reflecting the potential influence of both sources (biosilica/ash dissolution) and sinks (formation of authigenic clay minerals).

At Site U1419, both ammonium and alkalinity show relatively high concentrations, indicating intense diagenesis likely driven by the input of reactive organic matter, possibly reflecting the location of Site U1419 adjacent to the coastal Alaskan high-productivity zone (Stabeno et al., 2004). Ammonium and alkalinity both exhibit broad maxima between 20 and $90 \mathrm{~m}$ CCSF-B, indicating that the most intense organic matter degradation is occurring within the methanogenic zone. This process also seems to release organic matter-derived bromide, boron, and phosphate into solution.

The biogeochemical processes at Site U1419 follow the catabolic reaction sequence (Froelich et al., 1979), with the exception that manganese reduction is completed above the depth of the uppermost IW sample. Iron reduction appears to be quantitatively unimportant for organic matter remineralization, at least within the sampled sediment intervals, as indicated by low dissolved iron concentrations. However, rapid precipitation of iron monosulfides within 
sulfidic microenvironments might also contribute to the removal of dissolved iron from pore solution. Total sulfate depletion is reached at $\sim 20$ m CCSF-B, concomitant with the onset of methane production, indicating anaerobic oxidation of methane coupled to sulfate reduction in a sulfate-methane transition zone (SMTZ). Dissolved calcium, magnesium, and strontium exhibit sinks within the SMTZ, likely related to the formation of authigenic carbonates. Deeper than the SMTZ, the release of barium and strontium to the pore waters indicates dissolution of barite under sulfate-depleted conditions in methanogenic sediments. Authigenic barite reprecipitation at the SMTZ most likely acts as a sink for dissolved barium (von Breymann et al., 1992).

At Site U1419, chloride concentrations, salinity, and sodium decrease substantially with depth. Dehydration of clay minerals should not occur at such shallow burial depths (Saffer and McKiernan, 2009). Reduced IW salinities have been frequently observed in sediments overlying methane hydrate reservoirs (e.g., Hesse, 2003; Torres et al., 2004) because of the low-salinity water released upon hydrate dissociation. No bottom simulating reflector is observed at Site U1419 (see "Background and objectives") Despite this lack of geophysical evidence for gas hydrate deposits at Site U1419, the water depth of $~ 750$ $\mathrm{m}$ is within the gas hydrate stability window (Hesse, 2003). Finely disseminated gas hydrates would not necessarily be visible in seismic profiles as a bottomsimulating reflector (Shipley et al., 1979; Hesse, 2003), and significant gas expansion of Site U1419 cores proves that high concentrations of gas (possibly from dissociated hydrates) are present in these deposits. The moderate methane concentrations analyzed in headspace samples may be an underestimate of the real gas contents of the deposits in the coarser lithologies.

Alternatively, studies on marine IW salinities adjacent to modern ice sheets of Greenland (Ocean Drilling Program Leg 152; Gieskes et al., 1998; DeFoor et al., 2011) and Antarctica (Lu et al., 2010) have revealed that substantial IW freshening might be related to glacial meltwater discharge events. It is likely that during glacial maxima an ice front extended from the southern Alaskan coastline adjacent to Site U1419 over much of the continental shelf, potentially reaching the shelf break (Carlson and Bruns, 1997; Davies et al., 2011). Subglacial meltwater or submarine groundwater discharge could have caused infiltration of freshwater into the underlying sediments, followed by its transport through permeable shelf sediments down to the upper slope. However, based on shipboard analyses alone, it is impossible to discern whether gas hydrates or glacial meltwater caused the observed IW freshening.

\section{Physical properties}

Physical properties measurements were taken in each of the five holes drilled at Site U1419 to provide basic information for characterizing the drilled section using whole-round cores, split cores, and discrete samples. After cores were divided into sections, all whole-round core sections longer than $\sim 30 \mathrm{~cm}$ were measured through the GRA bulk densitometer and MS loop on the STMSL at $2.5-5.0 \mathrm{~cm}$ intervals with 2 $\mathrm{s}$ measurements. GRA bulk density and MS were measured with the WRMSL at $2.5 \mathrm{~cm}$ intervals with $5 \mathrm{~s}$ measurements. Compressional ( $P$-wave) velocity was measured on the WRMSL for Holes U1419CU1419E, although this data set is incomplete downcore because of complications associated with gas expansion, void spaces, and recovery (see "Compressional wave velocity"). After WRMSL scanning, whole-round sections were logged for NGR at $10 \mathrm{~cm}$ intervals. Color spectrometry, color reflectance, and MS were measured on the split cores using the SHMSL at $2.5 \mathrm{~cm}$ resolution. Discrete $P$-wave measurements and shear strength measurements were made on the working-half sections of split sediment cores from Hole U1419A on the Section Half Measurement Gantry. Moisture and density (MAD) were measured on $10 \mathrm{~cm}^{3}$ plugs collected from the working halves from Hole U1419A. Summaries of all the physical properties measured with the multisensor loggers on each hole, as well as discrete bulk density and $P$-wave velocity, are provided in Figures F22, F23, F24, F25, and F26.

\section{Gamma ray attenuation bulk density}

Variations in GRA bulk density at Site U1419 likely reflect changes in mineralogy/lithology, consolidation, and porosity. Whole-round GRA bulk density averages $\sim 1.93 \mathrm{~g} / \mathrm{cm}^{3}$ in the APC cores and displays downhole cyclic variability on the order of $\sim 0.2 \mathrm{~g} / \mathrm{cm}^{3}$ (Figs. F22, F23, F24, F25, F26). There are two intervals of anomalously low $\left(<1.8 \mathrm{~g} / \mathrm{cm}^{3}\right)$ GRA bulk density in the recovered stratigraphic section between $\sim 0$ and $6 \mathrm{~m}$ CCSF-B and between $\sim 80$ and $87 \mathrm{~m}$ CCSF-B (Fig. F22). Incomplete recovery complicates interpretation of the diamict intervals that comprise the deepest recovered material; however, shallower than 120 m CCSF-B a general trend toward higher densities with depth is consistent with sediment consolidation/compaction.

\section{Magnetic susceptibility}

As outlined in "Physical properties" in the "Site U1417" chapter (Jaeger et al., 2014b), for purposes of comparison the WRMSL loop and point-source MS data sets were both smoothed using a Gaussian filter 
of $10 \mathrm{~cm}( \pm 3 \sigma)$ and then interpolated to constant resolution (note those data in the LIMS database are recorded at their raw measurement resolution). We find an offset in the relative magnitude of the measurements, with loop MS being on average $1.52 \times$ greater than the point-source data collected from Holes U1419A-U1419E (Fig. F27). This ratio is lower than that observed for Sites U1418 and U1417; the ratios of loop to point-source MS appear to fall into two populations as opposed to trending along a line. The existence of these two populations may be related to poor contact of the point-source MS meter with the core surface in the diamict section, gas expansion of the core sections between measurement by the loop and point-source sensors, and/or an issue with the calibration of one of the instruments. We evaluate all volumetric MS measurements in instrument units (IU) because of the lack of available absolute calibration standards (see "Physical properties" in the "Methods" chapter [Jaeger et al., 2014a]).

We normalize loop MS for changes in sediment recovery and compaction by dividing the volumetric mass susceptibility by the GRA bulk density after Gaussian smoothing both data sets with a filter of $10 \mathrm{~cm}( \pm 3 \sigma)$ to correct for the differing response functions of the instruments. This generates a mass MS $(\chi)$ with units of cubic centimeters per gram (Fig. F28). Correcting for changes in sediment volume reduces the variance in $\chi$ by $\sim 20 \%$, relative to the equivalently smoothed raw WRMSL MS data normalized by the mean GRA core density. Mass MS averages $\sim 68 \mathrm{~cm}^{3} / \mathrm{g}$ downhole at the site (Fig. F28). Recurring variability between 55 and $90 \mathrm{~cm}^{3} / \mathrm{g}$ is present in the core shallower than $\sim 80$ m CCSF-B, potentially transitioning to variability of increased amplitude and reduced frequency at greater depths, although reduced core recovery limits interpretation.

\section{Compressional wave velocity}

$P$-wave velocity was measured on the WRMSL $P$ wave logger (PWL) in Holes U1419C-U1419E. We were unable to use the PWL on Holes U1419A and U1419B because the $P$-wave pulser box failed on the Section Half Measurement Gantry. As a result, the pulser box for the WRMSL system had to be shared between the tracks for the remainder of the cruise. A near-continuous record of velocities was captured in Holes U1419C-U1419E between $\sim 5$ and $25 \mathrm{~m}$ CSF-A (Fig. F29). Deeper than 25 m CSF-A, velocity measurements were compromised because of the nature of the recovered sediment. Much of the sediment was diamict with variable clast sizes (see "Lithostratigraphy"). Often, this facies was not consolidated and void spaces developed during recovery that de- coupled the core material from the liner. Core quality was also compromised by gas expansion shallower than $\sim 100 \mathrm{~m}$ CSF-A. Large gaps in core recovery deeper than $\sim 120 \mathrm{~m}$ CSF-A are present in Hole U1419A.

Discrete $P$-wave measurements using the $P$-wave caliper (PWC) tool (see "Physical properties" in the "Methods" chapter [Jaeger et al., 2014a]) were taken in Hole U1419A. Void spaces within the unconsolidated sections and gas expansion compromised PWC velocity measurements. Combined with poor core recovery, these compromised measurements meant we were unable to obtain velocities in the following depth intervals: $\sim 5$ to $\sim 40, \sim 45$ to $\sim 58, \sim 69$ to $\sim 98$, and $\sim 120$ to $\sim 140 \mathrm{~m} \mathrm{CCSF-B} \mathrm{(Fig.} \mathrm{F30).} \mathrm{PWC}$ values show no significant overall trend with depth, although a region of higher velocity is observed at $\sim 120 \mathrm{~m}$ CCSF-B where velocities increase to $\sim 1800$ $2100 \mathrm{~m} / \mathrm{s}$ (Fig. F30). PWC values were automatically picked where possible and manually picked when the automatic picker encountered errors where the calipers did not have sufficient contact with the sample because of very soft sediment or bad coupling with the liner.

A single PWC measurement was completed within the uppermost $\sim 25 \mathrm{~m}$ CCSF-B of Site U1419, so there is little overlap between the PWC and PWL velocity measurements (Fig. F30). Some overlap occurs between the measurements in intervals near 40, 60, and $100 \mathrm{~m}$ CCSF-B where the values appear well correlated, but there is not enough overlap to construct a statistically significant scatter plot (Fig. F30). Although we believe that the few measurements we were able to obtain are reasonable, care must be taken when making interpretations based on these velocity data because the sampling is biased by both core recovery and variable measurement frequency of different lithologies. All discrete measurements at this site were taken within the dominant lithology of the recovered interval.

\section{Natural gamma radiation}

NGR was measured at $10 \mathrm{~cm}$ intervals on all wholeround core sections that exceeded $50 \mathrm{~cm}$ in length (Fig. F31), with minimum section length limited by the response function of the sodium iodide detectors (see "Physical properties" in the "Methods" chapter [Jaeger et al., 2014a]). Each measurement reflects the integration of $5 \mathrm{~min}$ of counts (i.e., $10 \mathrm{~min}$ of counting per section, consisting of $5 \mathrm{~min}$ at each of two positions separated by $10 \mathrm{~cm}$ ). NGR measurements show recurring downhole variations between 14 and 43 counts per second (cps) with a mean and standard deviation of 32 and 4, respectively. Downcore variability in raw NGR values closely parallel changes in 
GRA bulk density. Two notable intervals of reduced raw NGR $(<30$ cps) occur between $\sim 0$ and 6 m CCSF$\mathrm{B}$ and between $\sim 80$ and $87 \mathrm{~m}$ CCSF-B, correlated with lows in GRA bulk density (Fig. F31) and WRMSL MS (Fig. F28), corresponding to the uppermost and lowermost part of lithostratigraphic Unit 1 , respectively (see "Lithostratigraphy").

As with WRMSL MS, we calculate an equivalent activity of the sediment by normalizing to the raw GRA bulk density after Gaussian smoothing the data sets to $50 \mathrm{~cm}( \pm 3 \sigma)$ to accommodate for the varying response functions of the instruments. This treatment reduces the overall variance in the NGR record by $\sim 30 \%$ relative to the Gaussian-smoothed uncorrected NGR data normalized by the mean core GRA bulk density. The decrease in raw NGR observed shallower than $6 \mathrm{~m}$ CCSF-B is preserved; however, the low in raw NGR between $\sim 80$ and $87 \mathrm{~m}$ CCSF-B is not apparent in mass-normalized NGR activity, which suggests that the composition of the lithogenic component in this interval is likely similar to that at the surrounding depths. Low-frequency variability in NGR activity is roughly characterized by a downhole increase between 0 and $120 \mathrm{~m}$ CCSF-B in Holes U1419A-U1419E. This trend may be arrested or partially reversed below $120 \mathrm{~m}$, although this observation is uncertain because of poor core recovery (Fig. F31).

\section{Moisture and density}

Bulk density values in Hole U1419A were calculated from mass and volume measurements on discrete samples taken from the working halves of split cores (see "Physical properties" in the "Methods" chapter [Jaeger et al., 2014a]). Depending on core recovery, quality, and lithology, one to three samples were taken per core. A total of 46 samples were analyzed for MAD.

MAD values correspond well with GRA bulk densities measured on the WRMSL for Hole U1419A, increasing downhole from $\sim 1.5-1.6 \mathrm{~g} / \mathrm{cm}^{3}$ at the seafloor to $\sim 2.2-2.4 \mathrm{~g} / \mathrm{cm}^{3}$ at $\sim 120 \mathrm{~m}$ CCSF-B. The interval between $\sim 120$ and $\sim 140 \mathrm{~m}$ CCSF-B was not recovered. Deeper than 140 CCSF-B, density increases from $\sim 2.0-2.1$ to $2.2 \mathrm{~g} / \mathrm{cm}^{3}$ by $\sim 180 \mathrm{~m}$ CCSF-B (Fig. F32).

Bulk grain density values range between 2.7 and 2.9 $\mathrm{g} / \mathrm{cm}^{3}$ shallower than $\sim 30 \mathrm{~m}$ CCSF-B. Between $\sim 40$ and $\sim 90 \mathrm{~m}$ CCSF-B, grain density values show reduced variability around $\sim 2.8 \mathrm{~g} / \mathrm{cm}^{3}$. Deeper than $\sim 90 \mathrm{~m}$ CCSF-B, grain density values again show greater scatter, ranging from $\sim 2.7$ to $3.0 \mathrm{~g} / \mathrm{cm}^{3}$ (Fig. F33).

Porosity measured on discrete samples generally decreases with depth. There was increased scatter be- tween $\sim 60$ and $100 \mathrm{~m}$ CCSF-B and a population of anomalously low porosity observed at $\sim 115 \mathrm{~m}$ CCSFB (Fig. F33).

\section{Shear strength}

Shear strength measurements were performed on working section halves from Hole U1419A using the automated vane shear testing system (see "Physical properties" in the "Methods" chapter [Jaeger et al., 2014a]). Efforts were taken to avoid the locations of obvious drilling disturbance or cracks in the halfcore sample. Measurements were taken as close as possible to the positions of the MAD samples and PWC measurements.

Shear strength indicates that sediments range from very soft $(0-20 \mathrm{kPa})$ to stiff (up to $79 \mathrm{kPa})$. Generally, shear strength increases with depth at a constant rate. An anomalous interval of elevated shear strength $(\sim 60-79 \mathrm{kPa})$ is present at $\sim 120 \mathrm{~m}$ CCSF-B (Fig. F34). This interval coincides with an increase in both $P$-wave velocity (Fig. F30) and density and a decrease in porosity (Fig. F33). Gaps in the measurement record reflect intervals of poor recovery. All samples were taken in the dominant matrix lithology of the recovered sediment.

\section{Paleomagnetism}

The natural remanent magnetization (NRM) of Site U1419 archive-half cores was measured and remeasured after alternating field (AF) demagnetization. Peak AFs were restricted to a maximum of $20 \mathrm{mT}$ for all sections recovered using the APC system with full and half-length, nonmagnetic and steel core barrels (see "Operations") and recovered using the XCB system (Table T11). The number of demagnetization steps and the peak field used reflect the demagnetization characteristics of the sediments, the severity of the drill string magnetic overprint, the desire to use low peak fields to preserve the magnetization for future shore-based studies, and the need to maintain core flow through the laboratory. When time permitted, additional demagnetization steps were added for the uppermost few cores of Holes U1419B and U1419C to facilitate magnetic interpretation. Sections completely affected by drilling disturbance, as noted by the Lithostratigraphy and/or Paleomagnetism groups, were not measured. Data associated with intervals affected by obvious drilling deformation or measurement error (flux jumps; e.g., Richter et al., 2007) were culled prior to uploading or during data processing.

The NRM intensities of materials recovered with the APC (Holes U1419A-U1419E) and XCB (Cores 341U1419A-21X through 29X) systems were strong be- 
fore $\mathrm{AF}$ demagnetization $\left(10^{-1} \mathrm{~A} / \mathrm{m}\right)$, but in contrast to Sites U1417 and U1418, there was a larger reduction in intensity after demagnetization $\left(10^{-2}\right.$ to $10^{-4}$ $\mathrm{A} / \mathrm{m}$ ). Transformation of depths to the CCSF-B scale (see "Stratigraphic correlation") using the multiple APC-drilled holes allows results to be compared between holes. On the CCSF-B depth scale, intensities are consistent between holes and vary at both the meter and decameter scales (Fig. F35). Discrete intervals of very low intensities observed during intervals with biosiliceous ooze and diatom-rich mud suggest a relationship between magnetic mineralogy, lithology (see "Lithostratigraphy"), and potentially redox chemistry (see "Geochemistry"). No clear correlation between core barrel type (full length nonmagnetic, full-length steel, or half-length steel) and magnetization was observed.

Steep, positive inclinations observed in the APC section prior to demagnetization, likely due to the drill string magnetic overprint, were generally removed by peak AF demagnetization of $10 \mathrm{mT}$ (Fig. F36). Inclinations are near values expected for a geocentric axial dipole (approximately $\pm 73.5^{\circ}$ ) at the site's latitude, although intervals of shallower than expected or even reversed inclination are observed. These are not thought to reflect a change in polarity but instead either core disturbance in the clast-rich facies or potentially geomagnetic events. As a result, the sediment recovered is thought to be exclusively within the Brunhes Chronozone and younger than $0.781 \mathrm{Ma}$ (Cande et al., 1995; Hilgen et al., 2012).

Shore-based analyses will allow significant refinement of these interpretations, especially within the APC-recovered section where lithologic variability and core disturbance influenced the shipboard magnetic record. Much of the ambiguity could result from the low level of AF demagnetization used that did not fully remove the drill string overprint and the inclusion of sections with minor deformation. Focusing on the splice that contains the best-recovered intervals, sampling within the most pristine central part of the core, and targeting better preserved and specific lithologies with discrete samples would likely lead to more reliable results.

\section{Core-log-seismic integration}

\section{Seismic profiles and seismic units}

Two seismic lines cross Site U1419: GOA3101 (Fig. F37) and GOA3102 (Fig. F38), both acquired in 2004 aboard the R/V Maurice Ewing as a part of a site survey cruise for Expedition 341. In preparation for core-seismic integration, we divided the two profiles into seismic units defined by either changes in acoustic facies or truncation surfaces. Some of these seismic units are characterized by distinct internal packages, which are either separated by a high-amplitude, continuous reflector or distinguished by a minor change in seismic character.

At a gross scale, seismic character across both profiles changes from laterally continuous subhorizontal reflectors (seismic Units A and B) to generally more chaotic facies with intermittent semicontinuous units deeper than Unit B (Units C-G) at $~ 997 \mathrm{~ms}$ TWT at Site U1419. On seismic Profile 3101, an erosional surface is present at the bottom of Unit $\mathrm{D}$ and the underlying units, $\mathrm{E}$ and $\mathrm{F}$, are truncated between common depth points 300 and 500 (Fig. F37). On seismic Line 3102, the bottom boundary of Unit $\mathrm{E}$ forms an erosional surface that truncates Unit $\mathrm{F}$ in the common depth point range $\sim 650-700$. Strata in Unit $F$ are also truncated by the underlying Unit $G$, which forms a lobate mound and provides an onlap surface for Unit F (Fig. F38). This mound thins to the northeast, but it is unclear whether it tapers off completely. On Profile GOA3101, units deeper than Unit G (Units H-K) appear conformable; however, Profile 3102 reveals a more complicated geometric relationship in which the underlying units are subhorizontal in the northeast-southwest direction, whereas the overlying unit boundaries and the seafloor show a draped geometry deepening both to the northeast and to the southwest.

To correlate lithostratigraphic units and changes in core physical properties to features observed in the seismic data, we first converted CCSF-B to TWT using the average $P$-wave velocity of each unit. Average $P$-wave velocity was derived from physical properties measurements at Site U1419 (see "Physical properties"). For the upper $\sim 25 \mathrm{~m}$ CCSF-B, we used velocities from both the PWL and PWC. For the interval between $\sim 25$ and $95 \mathrm{~m}$ CCSF-B, we used the average of the few PWL and PWC measurements to interpolate seismic velocities. From $\sim 100 \mathrm{~m}$ CCSF-B to the base of the hole, we used average PWC velocities within each unit.

Seismic Unit A is defined by two high-amplitude, continuous reflectors between the seafloor and $\sim 937$ ms TWT. Lithologically, this seismic unit correlates with a gray diatom ooze interval that comprises the uppermost $\sim 6 \mathrm{~m}$ CCSF-B of the core (see "Lithostratigraphy"). Physical properties measured in this interval reveal relatively low MS, $P$-wave velocity, and density (Fig. F39). Seismic Unit B ( 937 to 997 ms TWT) features conformable, subhorizontal, continuous reflectors. An 18 ms thick section of negative polarity, low-amplitude, seismically transparent material is located at the top and bottom of this seismic unit. In the core, this interval consists of gray mud 
with lonestones. Some of the MS peaks in this interval may be associated with occasional sand layers (Fig. F39), whereas other peaks may be associated with individual clasts. The presence of diatomaceous material within this interval correlates with lows in MS at $\sim 16$ and $\sim 60 \mathrm{~m} \mathrm{CCSF-B.}$

Seismic Unit C ( 997-1045 ms TWT) is defined by high-amplitude, semichaotic reflectors with some truncations. According to our depth to traveltime conversion, the lower portion of Unit C correlates to an interval of low MS and low density (Fig. F39). Lithologically, this interval consists of mud with lonestones, but an increase in lonestone abundance relative to lithologies corresponds with Unit B (see "Lithostratigraphy;" Fig. F9). The boundary between seismic Units C and D correlates to the boundary between lithostratigraphic Units I and II. In the lithostratigraphy, this boundary is defined by a change from mud with lonestones (Unit I) to muddy diamict interbedded with laminated mud and thin coarse sand beds (Unit II). Seismic Unit D ( 1045-1095 ms TWT) is composed of two packages of high-amplitude, semicontinuous reflectors. The lower portion of this unit correlates with an interval of high density and velocity between $\sim 113$ and $\sim 120$ $\mathrm{m}$ CCSF-B as measured on the core (Fig. F39). Lithologically, this interval consists of muddy diamict that is interbedded with laminated mud and thin coarse sand beds (part of lithostratigraphic Unit II).

Because of poor core recovery, correlations below $\sim 120 \mathrm{~m}$ CCSF-B are difficult. Given the average velocities of the recovered material, it appears that we were able to drill through seismic Units E and F (Figs. F37, F38); detailed correlation with the lithostratigraphy will require postcruise analysis. Seismic Unit E ( 1095-1105 ms TWT) is a low-amplitude interval with negative upper reflector that is seismically transparent. Seismic Unit F is a high-amplitude, semichaotic facies that is truncated along its upper boundary by seismic Unit E. The lower part of the core was primarily composed of muddy clast-poor diamict, with one small interval of diatomaceous material observed.

\section{References}

Addison, J.A., Finney, B.P., Dean, W.E., Davies, M.H., Mix, A.C., Stoner, J.S., and Jaeger, J.M., 2012. Productivity and sedimentary $\delta^{15} \mathrm{~N}$ variability for the last 17,000 years along the northern Gulf of Alaska continental slope. Paleoceanography, 27(1):PA1206. doi:10.1029/ 2011PA002161

Barron, J.A., Bukry, D., Dean, W.E., Addison, J.A., and Finney, B., 2009. Paleoceanography of the Gulf of Alaska during the past 15,000 years: results from diatoms, silicoflagellates, and geochemistry. Mar. Micropaleontol.,
72(3-4):176-195. doi:10.1016/j.marmicro.2009.04.006

Berger, A.L., Gulick, S.P.S., Spotila, J.A., Upton, P., Jaeger, J.M., Chapman, J.B., Worthington, L.A., Pavlis, T.L., Ridgway, K.D., Willems, B.A., and McAleer, R.J., 2008. Quaternary tectonic response to intensified glacial erosion in an orogenic wedge. Nat. Geosci., 1:793-799. doi:10.1038/ngeo334

Brzezinski, M.A., Villareal, T.A., and Lipschultz, F., 1998. Silica production and the contribution of diatoms to new and primary production in the central North Pacific. Mar. Ecol.: Prog. Ser., 167:89-104. doi:10.3354/ meps 167089

Cande, S.C., and Kent, D.V., 1995. Revised calibration of the geomagnetic polarity timescale for the Late Cretaceous and Cenozoic. J. Geophys. Res.: Solid Earth, 100(B4):6093-6095. doi:10.1029/94JB03098

Carlson, P.R., and Bruns, T.R., 1997. Bering Trough: a product of the Bering Glacier, Gulf of Alaska. In Davies, T.A., Bell, T., Cooper, A.K., Josenhans, H., Polyak, L., Solheim, A., Stoker, M.S., and Stravers, J.A. (Eds.), Glaciated Continental Margins: An Atlas of Acoustic Images: London (Chapman and Hall), 244-247. doi:10.1007/978-94011-5820-6_85

Cowan, E.A., Seramur, K.C., Cai, J., and Powell, R.D., 1999. Cyclic sedimentation produced by fluctuations in meltwater discharge, tides and marine productivity in an Alaskan fjord. Sedimentology, 46(6):1109-1126. doi:10.1046/j.1365-3091.1999.00267.x

Davies, M.H., Mix, A.C., Stoner, J.S., Addison, J.A., Jaeger, J., Finney, B., and Wiest, J., 2011. The deglacial transition on the southeastern Alaskan margin: meltwater input, sea level rise, marine productivity, and sedimentary anoxia. Paleoceanography, 26(2):PA2223. doi:10.1029/2010PA002051

DeFoor, W., Person, M., Larsen, H.C., Lizarralde, D., Cohen, D., and Dugan, B., 2011. Ice sheet-derived submarine groundwater discharge on Greenland's continental shelf. Water Resour. Res., 47(7):W07549. doi:10.1029/2011WR010536

Dugdale, R.C., Wilkerson, F.P., and Minas, H.J., 1995. The role of a silicate pump in driving new production. DeepSea Res., Part 1, 42(5):697-719. doi:10.1016/09670637(95)00015-X

Froelich, P.N., Klinkhammer, G.P., Bender, M.L., Luedtke, N.A., Heath, G.R., Cullen, D., Dauphin, P., Hammond, D., Hartman, B., and Maynard, V., 1979. Early oxidation of organic matter in pelagic sediments of the eastern equatorial Atlantic: suboxic diagenesis. Geochim. Cosmochim. Acta, 43(7):1075-1090. doi:10.1016/00167037(79)90095-4

Gasser, D., Bruand, E., Stüwe, K., Foster, D.A., Schuster, R., Fügenschuh, B., and Pavlis, T., 2011. Formation of a metamorphic complex along an obliquely convergent margin: structural and thermochronological evolution of the Chugach Metamorphic Complex, southern Alaska. Tectonics, 30(2):TC2012. doi:10.1029/ 2010TC002776

Gieskes, J.M., Schrag, D., Chan, L.-H., Zhang, L., and Murray, R.W., 1998. Geochemistry of interstitial waters. In 
Saunders, A.D., Larsen, H.C., and Wise, S.W., Jr. (Eds.), Proc. ODP, Sci. Results, 152: College Station, TX (Ocean Drilling Program), 293-305. doi:10.2973/

odp.proc.sr.152.228.1998

Gulick, S.P.S., Lowe, L.A., Pavlis, T.L., Gardner, J.V., and Mayer, L.A., 2007. Geophysical insights into the Transition fault debate: propagating strike slip in response to stalling Yakutat block subduction in the Gulf of Alaska. Geology, 35(8):763-766. doi:10.1130/G23585A.1

Gulick, S.P.S., Reece, R.S., Christeson, G.L., van Avendonk, H., Worthington, L.L., and Pavlis, T.L., 2013. Seismic images of the Transition fault and the unstable YakutatPacific-North American triple junction. Geology, 41(5):571-574. doi:10.1130/G33900.1

Hamme, R.C., Webley, P.W., Crawford, W.R., Whitney, F.A., DeGrandpre, M.D., Emerson, S.R., Eriksen, C.C., Giesbrecht, K.E., Gower, J.F.R., Kavanaugh, M.T., Peña, M.A., Sabine, C.L., Batten, S.D., Coogan, L.A., Grundle, D.S., and Lockwood, D., 2010. Volcanic ash fuels anomalous plankton bloom in subarctic northeast Pacific. Geophys. Res. Lett., 37(19):L19604. doi:10.1029/2010GL044629

Hasle, G.R., and Syvertsen, E.E., 1996. Marine diatoms. In Tomas, C.R. (Ed.), Identifying Marine Diatoms and Dinoflagellates: San Diego (Academic Press), 5-385. doi:10.1016/B978-012693015-3/50005-X

Hedges, J.I., Clark, W.A., Quay, P.D., Richey, J.E., Devol, A.H., and Santos, U.D., 1986. Compositions and fluxes of particulate organic material in the Amazon River. Limnol. Oceanogr., 31(4):717-738. doi:10.4319/ lo.1986.31.4.0717

Hesse, R., 2003. Pore water anomalies of submarine gashydrate zones as tool to assess hydrate abundance and distribution in the subsurface-what have we learned in the past decade? Earth-Sci. Rev., 61(1-2):149-179. doi:10.1016/S0012-8252(02)00117-4

Hilgen, F.J., Lourens, L.J., and Van Dam, J.A., 2012. The Neogene period. In Gradstein, F.M., Ogg, J.G., Schmitz, M.D., and Ogg, G.M. (Eds.), The Geologic Time Scale: Oxford (Elsevier), 923-978. doi:10.1016/B978-0-44459425-9.00029-9

Jaeger, J.M., Gulick, S.P.S., LeVay, L.J., Asahi, H., Bahlburg, H., Belanger, C.L., Berbel, G.B.B., Childress, L.B., Cowan, E.A., Drab, L., Forwick, M., Fukumura, A., Ge, S., Gupta, S.M., Kioka, A., Konno, S., März, C.E., Matsuzaki, K.M., McClymont, E.L., Mix, A.C., Moy, C.M., Müller, J., Nakamura, A., Ojima, T., Ridgway, K.D., Rodrigues Ribeiro, F., Romero, O.E., Slagle, A.L., Stoner, J.S., St-Onge, G., Suto, I., Walczak, M.H., and Worthington, L.L., 2014a. Methods. In Jaeger, J.M., Gulick, S.P.S., LeVay, L.J., and the Expedition 341 Scientists, Proc. IODP, 341: College Station, TX (Integrated Ocean Drilling Program). doi:10.2204/iodp.proc.341.102.2014

Jaeger, J.M., Gulick, S.P.S., LeVay, L.J., Asahi, H., Bahlburg, H., Belanger, C.L., Berbel, G.B.B., Childress, L.B., Cowan, E.A., Drab, L., Forwick, M., Fukumura, A., Ge, S., Gupta, S.M., Kioka, A., Konno, S., März, C.E., Matsuzaki, K.M., McClymont, E.L., Mix, A.C., Moy, C.M., Müller, J., Nakamura, A., Ojima, T., Ridgway, K.D., Rodrigues Ribeiro, F., Romero, O.E., Slagle, A.L., Stoner, J.S., St-Onge, G., Suto, I., Walczak, M.H., and Worthing- ton, L.L., 2014b. Site U1417. In Jaeger, J.M., Gulick, S.P.S., LeVay, L.J., and the Expedition 341 Scientists, Proc. IODP, 341: College Station, TX (Integrated Ocean Drilling Program). doi:10.2204/

iodp.proc.341.103.2014

Kamikuri, S., Motoyama, I., and Nishimura, A., 2008. Radiolarian assemblages in surface sediments along longitude $175^{\circ} \mathrm{E}$ in the Pacific Ocean. Mar. Micropaleontol., 69(2):151-172. doi:10.1016/j.marmicro.2008.07.005

Koizumi, I., 2008. Diatom-derived SSTs ( $T d^{\prime}$ ratio) indicate warm seas off Japan during the middle Holocene (8.23.3 kyr BP). Mar. Micropaleontol., 69(3-4):263-281. doi:10.1016/j.marmicro.2008.08.004

Ladd, C., Mordy, C.W., Kachel, N.B., and Stabeno, P.J., 2007. Northern Gulf of Alaska eddies and associated anomalies. Deep-Sea Res., Part I, 54(4):487-509. doi:10.1016/j.dsr.2007.01.006

Lisiecki, L.E., and Raymo, M.E., 2005. A Pliocene-Pleistocene stack of 57 globally distributed benthic $\delta^{18} \mathrm{O}$ records. Paleoceanography, 20(1):PA1003. doi:10.1029/ 2004PA001071

Lu, Z., Rickaby, R.E.M., Wellner, J., Georg, B., Charnley, N., Anderson, J.B., and Hensen, C., 2010. Pore fluid modeling approach to identify recent meltwater signals on the west Antarctic Peninsula. Geochem., Geophys., Geosyst., 11(6):Q06017. doi:10.1029/2009GC002949

Molnia, B.F., and Hein, J.R., 1982. Clay mineralogy of a glacially dominated, subarctic continental shelf: northeastern Gulf of Alaska. J. Sediment. Petrol., 52(2):515527. doi:10.1306/212F7F90-2B24-11D78648000102C1865D

Pavlis, T.L., Chapman, J.B., Bruhn, R.L., Ridgway, K., Worthington, L.L., Gulick, S.P.S., and Spotila, J., 2012. Structure of the actively deforming fold-thrust belt of the St. Elias orogen with implications for glacial exhumation and three-dimensional tectonic processes. Geosphere, 8(5):991-1019. doi:10.1130/GES00753.1

Perry, S.E., Garver, J.I., and Ridgway, K.D., 2009. Transport of the Yakutat terrane, Southern Alaska: evidence from sediment petrology and detrital zircon fission-track and U/Pb double dating. J. Geol., 117(2):156-173. doi:10.1086/596302

Plafker, G., 1987. Regional geology and petroleum potential of the northern Gulf of Alaska continental margin. In Scholl, D.W., Grantz, A., and Vedder, J.G. (Eds.), Petroleum Geology Potential of the Continental Margin of Western North America and Adjacent Ocean Basins. Earth Sci. Ser. (N. Y.), 6:229-268.

Plafker, G., Moore, J.C., and Winkler, G.R., 1994. Geology of the southern Alaska margin. In Plafker, G., and Berg, H.C. (Eds.), The Geology of North America (Vol. G): The Geology of Alaska: Boulder, CO (Geol. Soc. Am.), 389449.

Powell, R.D., and Molnia, B.F., 1989. Glacimarine sedimentary processes, facies and morphology of the southsoutheast Alaska shelf and fjords. Mar. Geol., 85(24):359-390. doi:10.1016/0025-3227(89)90160-6

Richter, C., Acton, G., Endris, C., and Radsted, M., 2007. Handbook for shipboard paleomagnetists. ODP Tech. Note, 34. doi:10.2973/odp.tn.34.2007 
Saffer, D.M., and McKiernan, A.W., 2009. Evaluation of in situ smectite dehydration as a pore water freshening mechanism in the Nankai Trough, offshore southwest Japan. Geochem., Geophys., Geosyst., 10(2):Q02010. doi:10.1029/2008GC002226

Sakshaug, E., 2004. Primary and secondary production in the Arctic Seas. In Stein, R., and Macdonald, R.W. (Eds.), The Organic Carbon Cycle in the Arctic Ocean: Heidelberg (Springer-Verlag), 57-82. doi:10.1007/978-3-64218912-8_3

Sancetta, C., 1982. Distribution of diatom species in surface sediments of the Bering and Okhotsk Seas. Micropaleontology, 28(3):221-257. doi:10.2307/1485181

Schubert, C.J., and Calvert, S.E., 2001. Nitrogen and carbon isotopic composition of marine and terrestrial organic matter in Arctic Ocean sediments: implications for nutrient utilization and organic matter composition. Deep-Sea Res., Part I, 48(3):789-810. doi:10.1016/ S0967-0637(00)00069-8

Shipley, T.H., Houston, M.H., Buffler, R.T., Shaub, F.J., McMillen, K.J., Ladd, J.W., and Worzel, J.L., 1979. Seismic evidence for widespread possible gas hydrate horizons on continental slopes and rises. AAPG Bull., 63(12):2204-2213.

Sisson, V.B., Poole, A.R., Harris, N.R., Cooper Burner, H., Pavlis, T.L., Copeland, P., Donelick, R.A., and McClelland, W., 2003. Geochemical and geochronologic constraints for genesis of a tonalite-trondhjemite suite and associated mafic intrusive rocks in the eastern Chugach Mountains, Alaska: a record of ridge-transform subduction. In Sisson, V.B., Roeske, S.M., and Pavlis, T.L. (Eds.), Geology of a Transpressional Orogen Developed During Ridge-Trench Interaction Along the North Pacific Margin: Spec. Pap.—Geol. Soc. Am., 371:293-326. doi:10.1130/ 0-8137-2371-X.293

Smith, W.O., Jr., Baumann, M.E.M., Wilson, D.L., and Aletsee, L., 1987. Phytoplankton biomass and productivity in the marginal ice zone of the Fram Strait during summer 1984. J. Geophys. Res.: Oceans, 92(C7):67776786. doi:10.1029/JC092iC07p06777

Stabeno, P.J., Bond, N.A., Hermann, A.J., Kachel, N.B., Mordy, C.W., and Overland, J.E., 2004. Meteorology and oceanography of the northern Gulf of Alaska. Continent. Shelf Res., 24(7-8):859-897. doi:10.1016/ j.csr.2004.02.007
Suto, I., Kawamura, K., Hagimoto, S., Teraishi, A., and Tanaka, Y., 2012. Changes in upwelling mechanisms drove the evolution of marine organisms. Palaeogeogr., Palaeoclimatol., Palaeoecol., 339-341:39-51. doi:10.1016/j.palaeo.2012.04.014

Torres, M.E., Teichert, B.M.A., Tréhu, A.M., Borowski, W., and Tomaru, H., 2004. Relationship of pore water freshening to accretionary processes in the Cascadia margin: fluid sources and gas hydrate abundance. Geophys. Res. Lett., 31:L22305. doi:10.1029/2004GL021219

von Breymann, M.T., Brumsack, H., and Emeis, K.C., 1992. Depositional and diagenetic behavior of barium in the Japan Sea. In Pisciotto, K.A., Ingle, J.C., Jr., von Breymann, M.T., Barron, J., et al., Proc. ODP, Sci. Results, 127/ 128 (Pt. 1): College Station, TX (Ocean Drilling Program), 651-665. doi:10.2973/odp.proc.sr.1271281.168.1992

Walinsky, S.E., Prahl, F.G., Mix, A.C., Finney, B.P., Jaeger, J.M., and Rosen, G.P., 2009. Distribution and composition of organic matter in surface sediments of coastal southeast Alaska. Cont. Shelf Res., 29(13):1565-1579. doi:10.1016/j.csr.2009.04.006

Weingartner, T.J., Danielson, S.L., and Royer, T.C., 2005. Freshwater variability and predictability in the Alaska Coastal Current. Deep-Sea Res., Part II, 52(1-2):161-191. doi:10.1016/j.dsr2.2004.09.030

Witmer, J.W., 2009. Neogene deposition, provenance, and exhumation along a tectonically active, glaciated continental margin, Yakataga and Redwood Formations, southern Alaska syntaxis [M.S. dissert.]. Purdue Univ., West Lafayette, Indiana. http://docs.lib.purdue.edu/ dissertations/AAI1476110/

Worthington, L.L., Gulick, S.P.S., and Pavlis, T.L., 2008. Identifying active structures in the Kayak Island and Pamplona zones: implications for offshore tectonics of the Yakutat microplate, Gulf of Alaska. In Freymueller, J.T., Haeussler, P.J., Wesson, R.L., and Ekström, G. (Eds.), Active Tectonics and Seismic Potential of Alaska. Geophys. Monogr., 179:257-268. doi:10.1029/179GM14

Worthington, L.L, Gulick, S.P.S., and Pavlis, T.L., 2010. Coupled stratigraphic and structural evolution of a glaciated orogenic wedge, offshore St. Elias orogen, Alaska. Tectonics, 29:TC6013-TC6039. doi:10.1029/2010TC002723

Publication: 22 November 2014 MS 341-105 
Figure F1. Perspective view of the northern Gulf of Alaska, showing major tectonic elements (black $=$ thrust faults). Relief is shown at $\sim 10 \times$ vertical exaggeration, with total vertical relief ranging from $<4000 \mathrm{~m}$ below sea level to $>5000 \mathrm{~m}$ above sea level. Orange $=$ seismic profiles from the St. Elias Erosion and Tectonics Project (STEEP) draped over topography. Green = seismic profiles from Cruise EW0408. Black line = USGS Line F-6-89GA-26. Figure modified from Gulick et al. (2013).

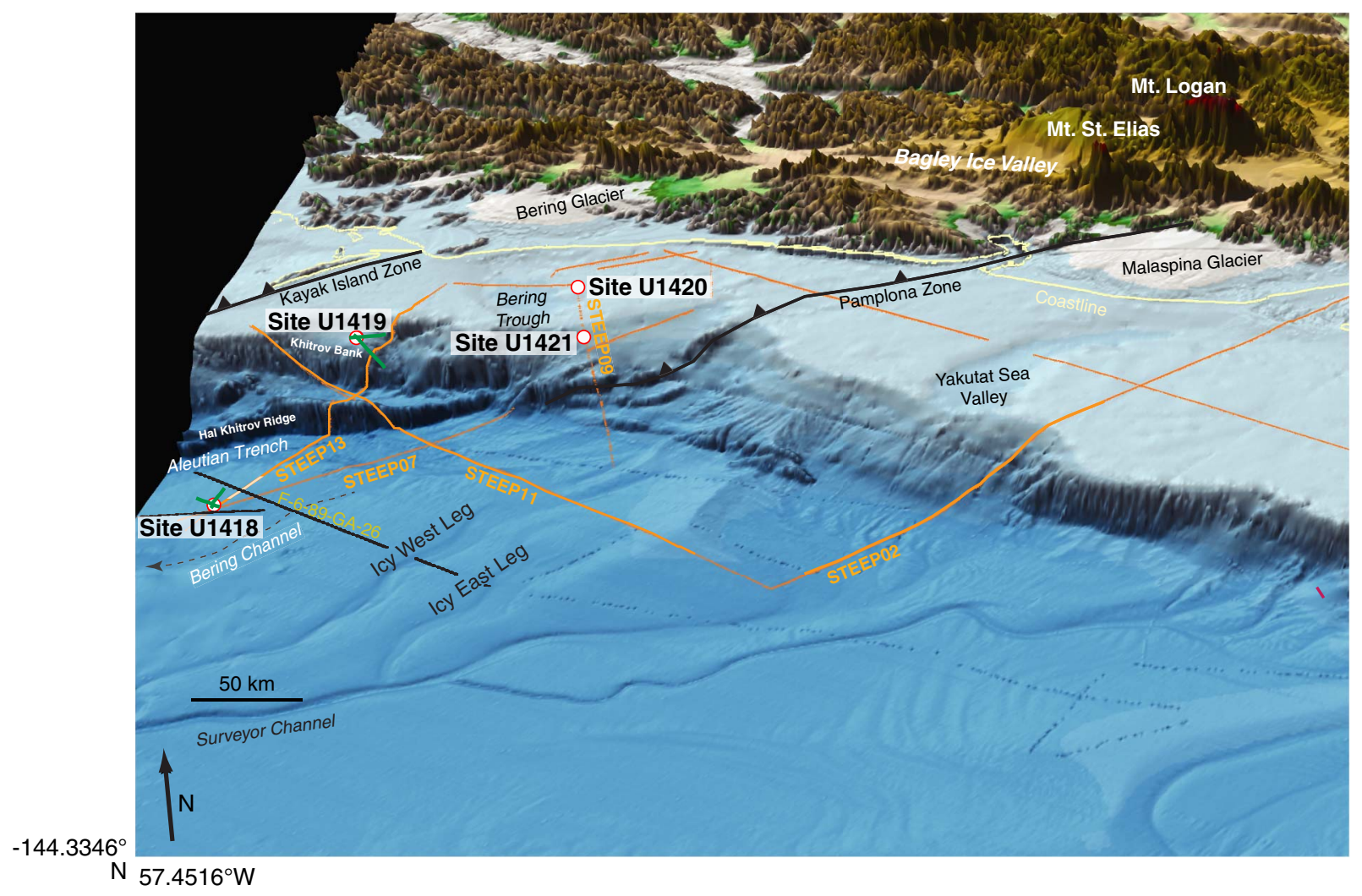


Figure F2. Navigation map, showing profiles and select shot points for two high-resolution generator-injector gun profiles, GOA3101 and GOA3102. CHIRP profiles were collected coincidently, and both types of data are shown in Figure F3. Inset shows location of proposed Expedition 341 sites. Common depth point locations labeled for each line.

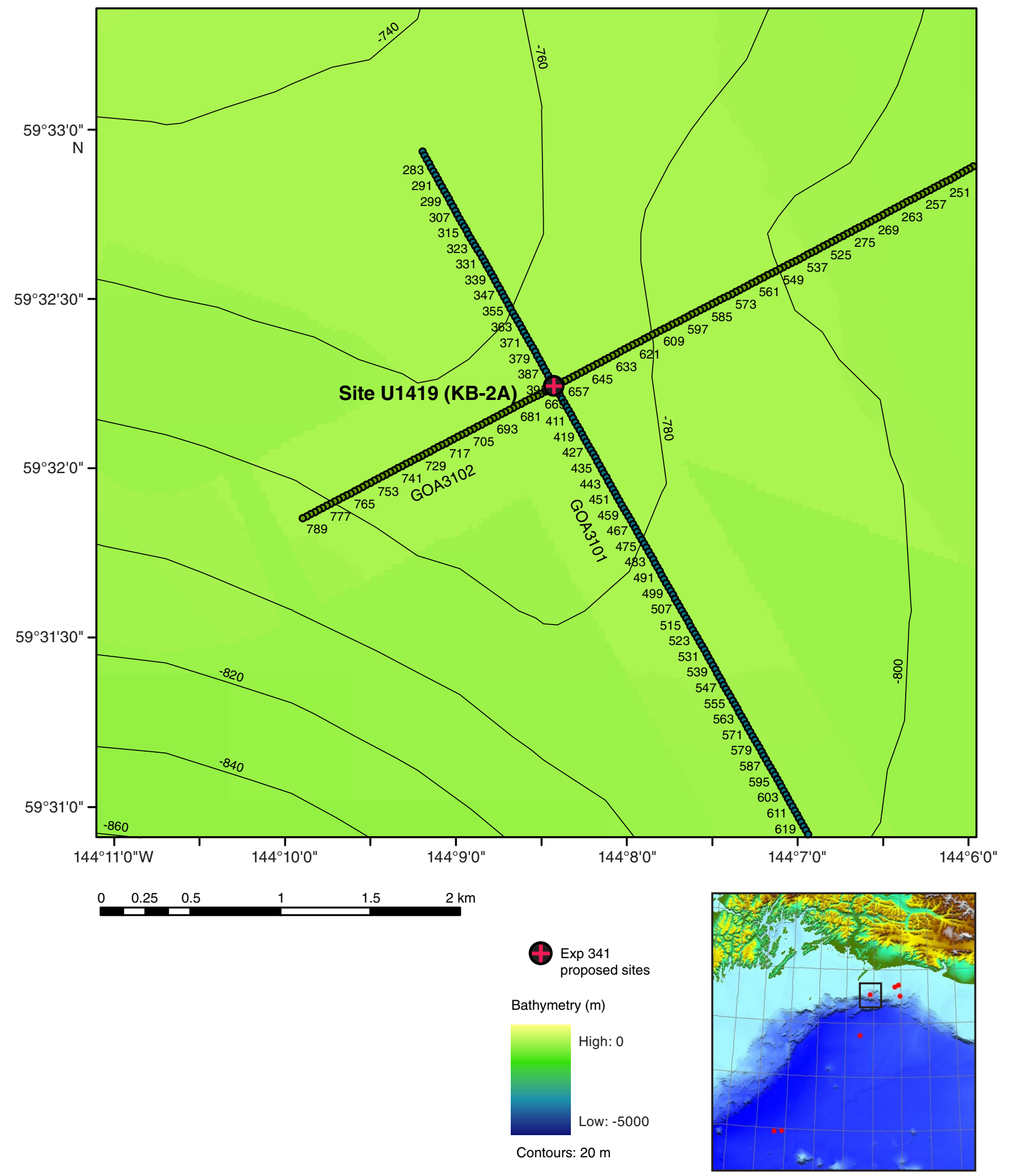


Figure F3. (A) High-resolution MCS Profiles GOA3101 (top) and GOA3102 (bottom) and (B) CHIRP images (collected coincident with MCS profiles) over Khitrov bank. Active deformation and faulting at seafloor soles into a transtensional flower structure, and Site U1419 is located upslope of these structures. Higher amplitude reflectors correspond with diamict in Core EW0408 85JC (located at the landward end of seismic Profile GOA3101) (Davies et al., 2011). LGM = Last Glacial Maximum. Proposed Expedition 341 Sites KB-1A and KB-2A (Site U1419) shown with proposed drilling depths. Vertical depth scale in meters based on seismic velocity of $2000 \mathrm{~m} / \mathrm{s}$.

A
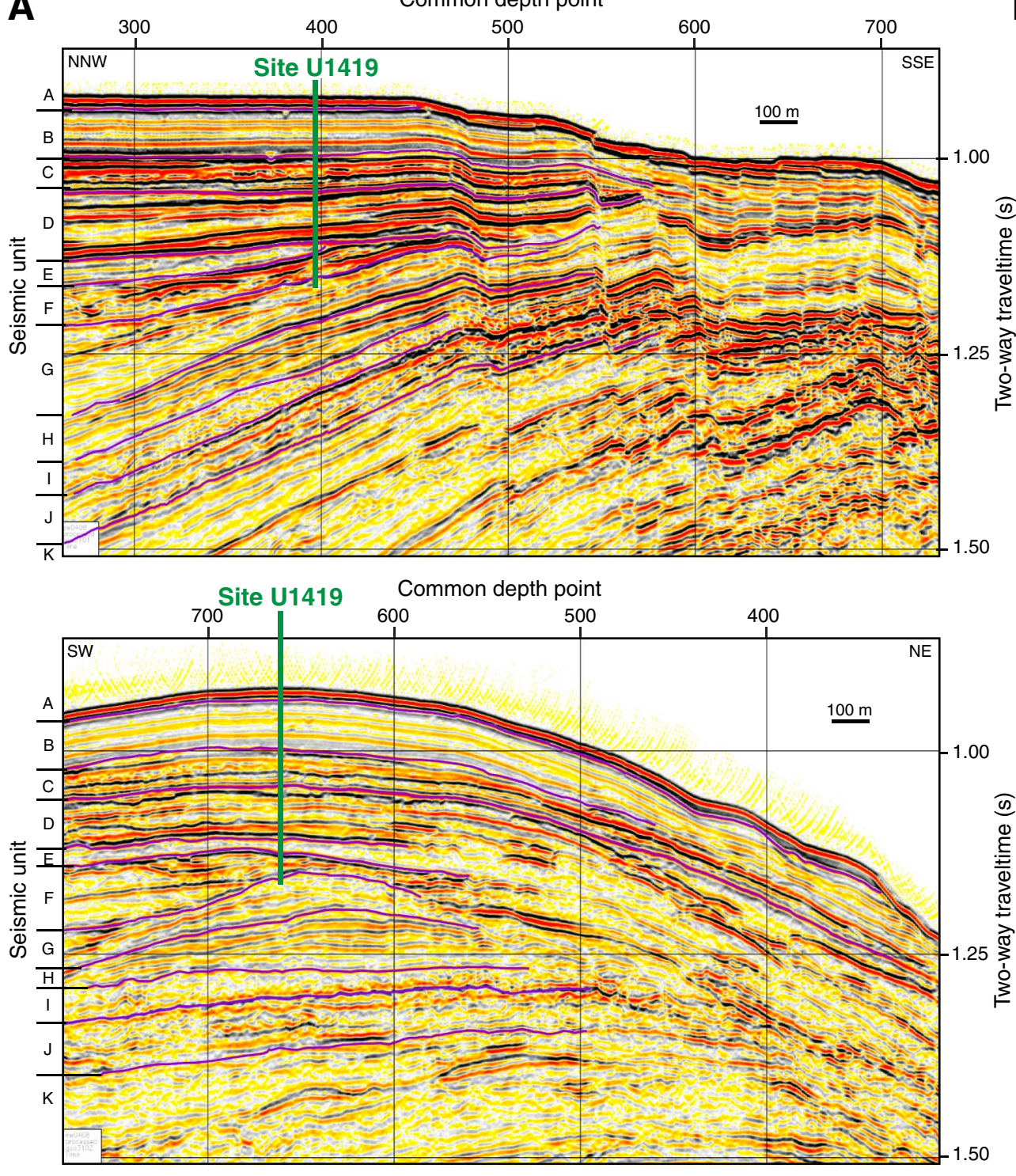

B

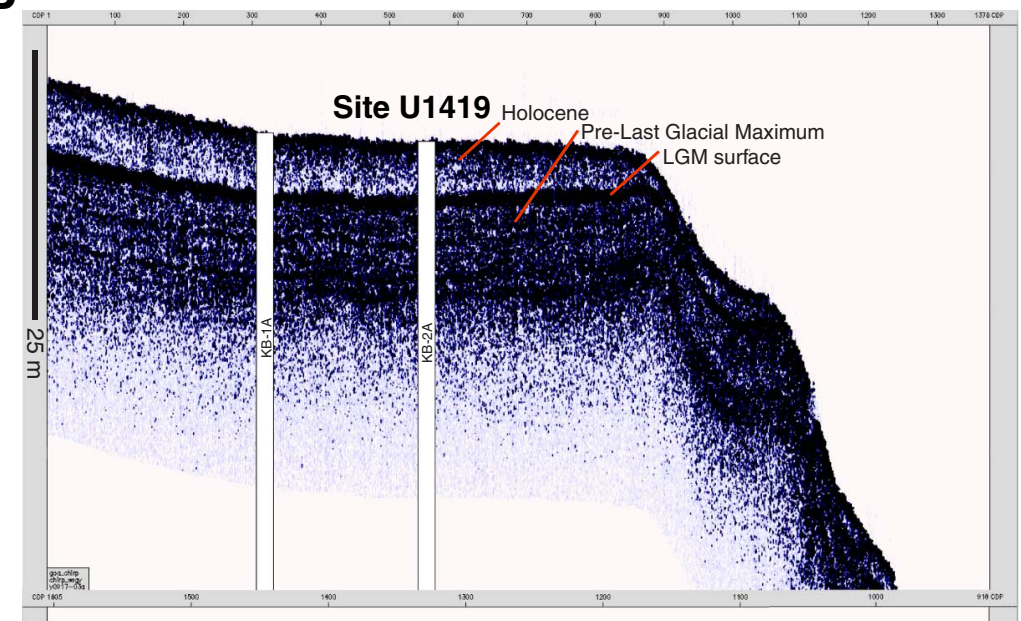

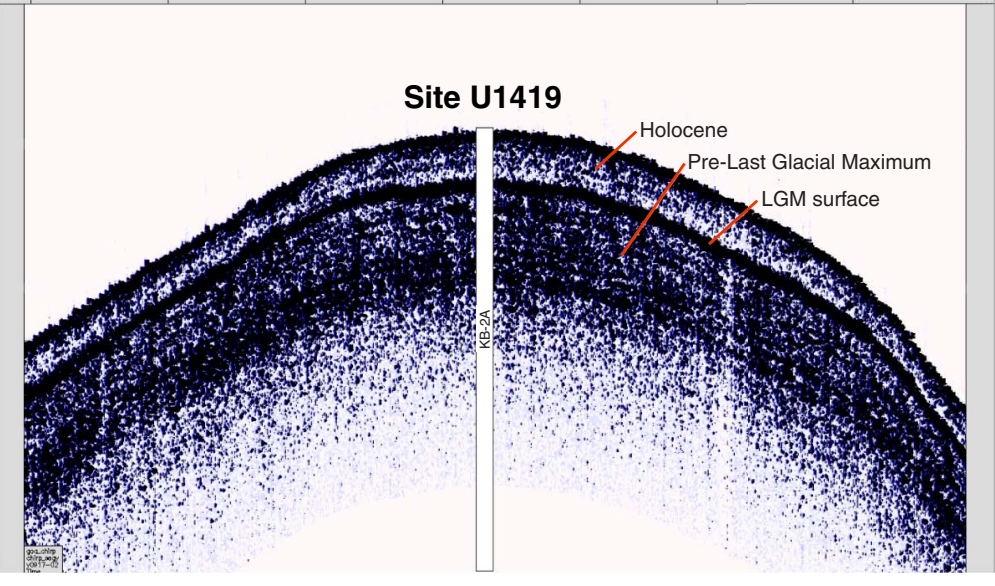


Figure F4. Close-up of high-resolution Profile GOA3101, with seismic Units A-K overlain. These units may represent strata formed under varying proximity to the ice margin. Proposed depth penetration for Site U1419 is shown.

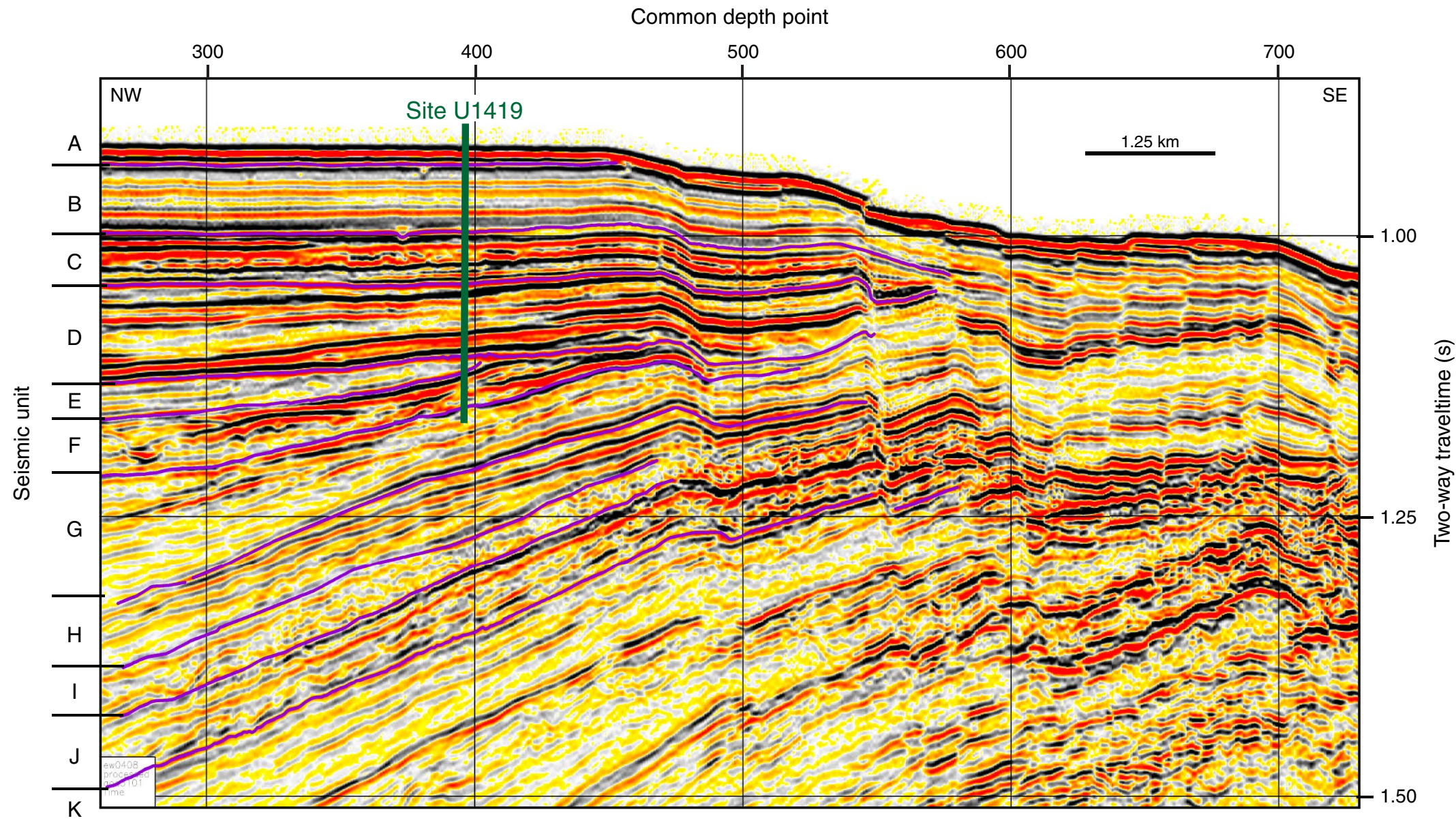


Figure F5. Core recovery, Site U1419.

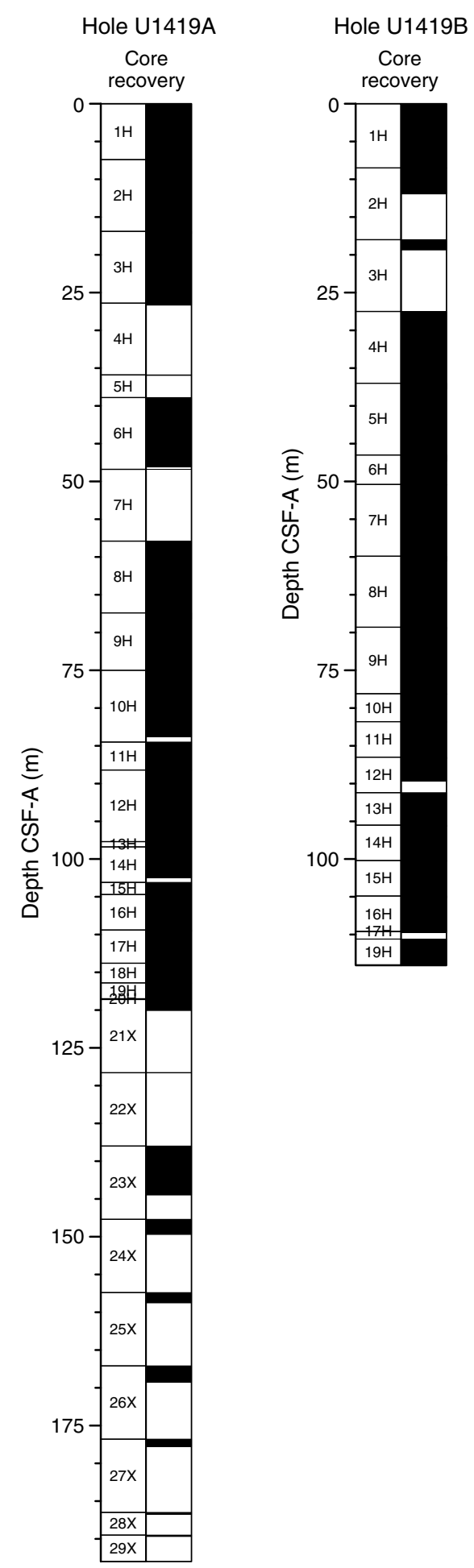

\section{Site U1419}

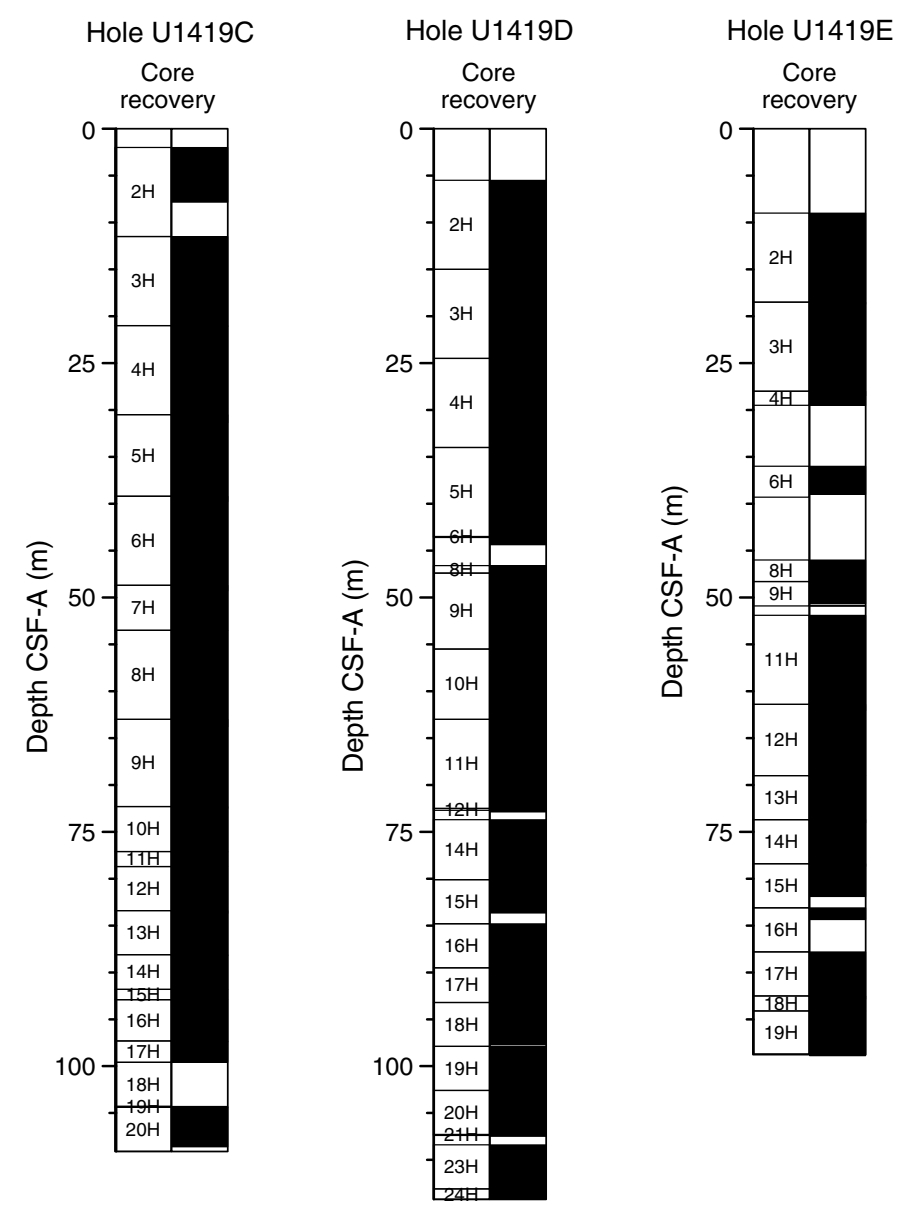


Figure F6. Hole summaries, Site U1419. Volcanic grain abundance: $1=$ trace, $2=$ volcaniclastic bearing, $3=$ volcaniclastic rich, 4 = ash. GRA = gamma ray attenuation. A. Hole U1419A. (Continued on next four pages.)

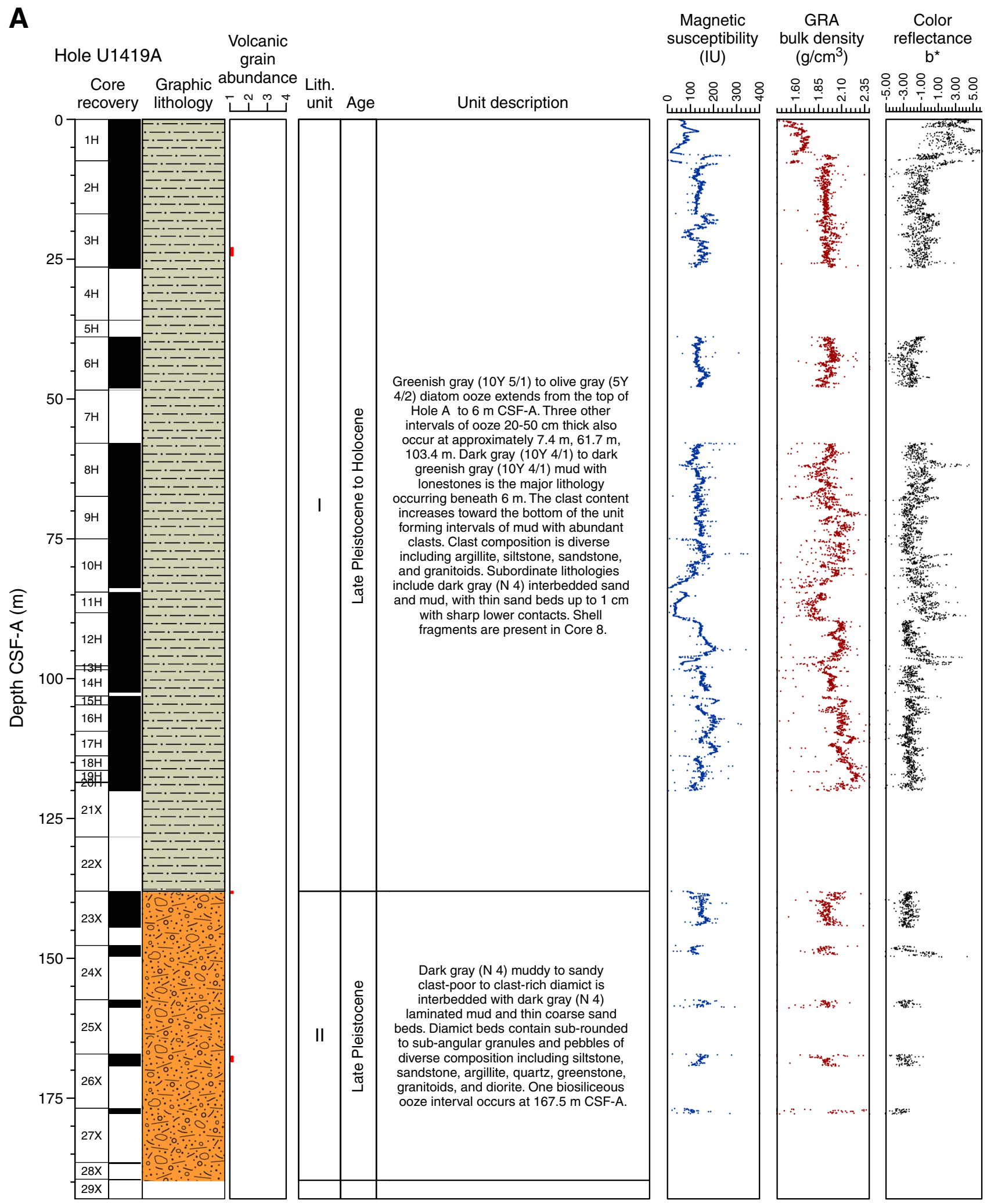


Figure F6 (continued). B. Hole U1419B. (Continued on next page.)

B

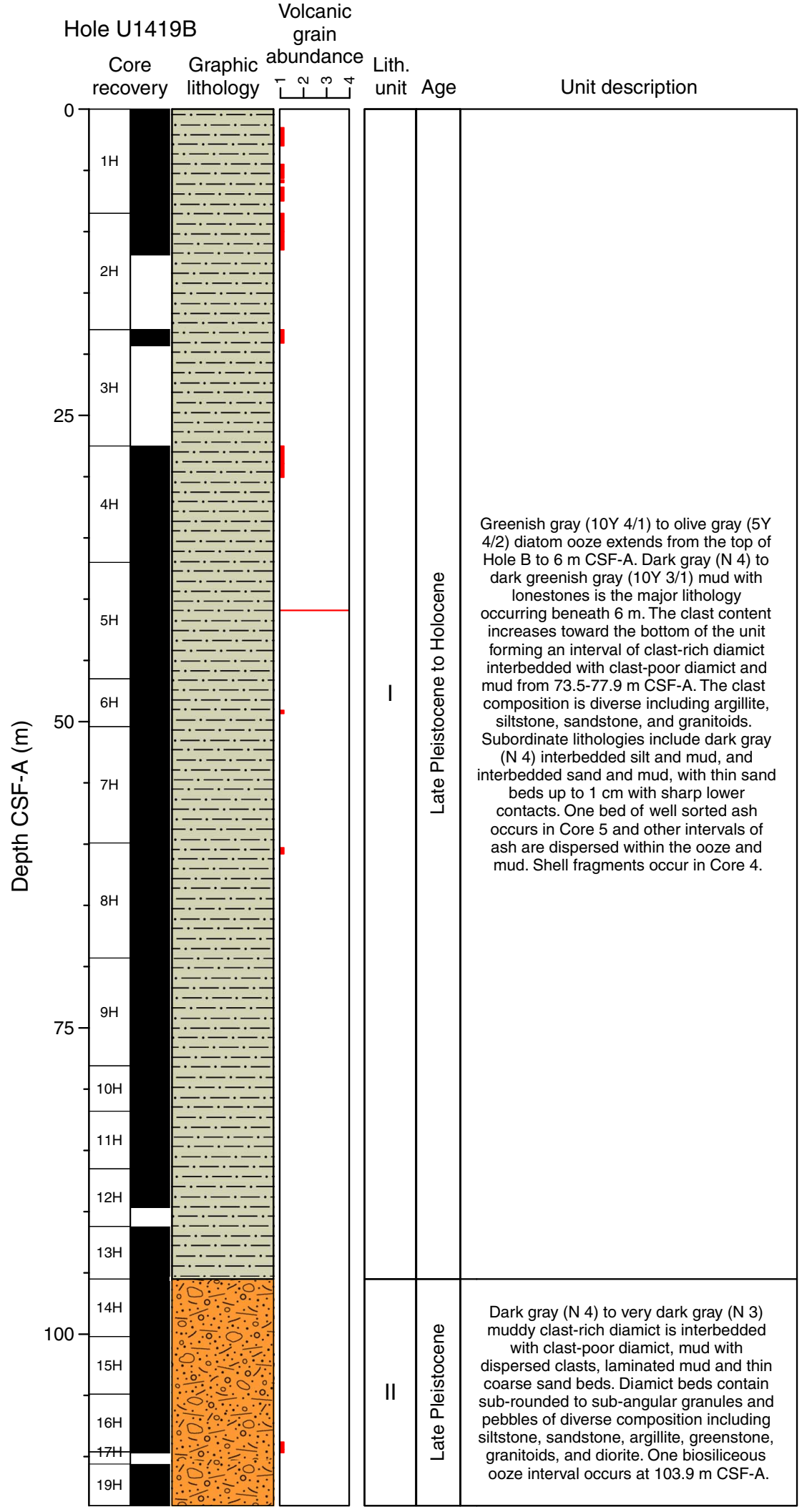

Magnetic

(IU)

GRA
bulk density
$\left(\mathrm{g} / \mathrm{cm}^{3}\right)$

Color

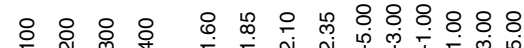

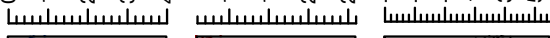

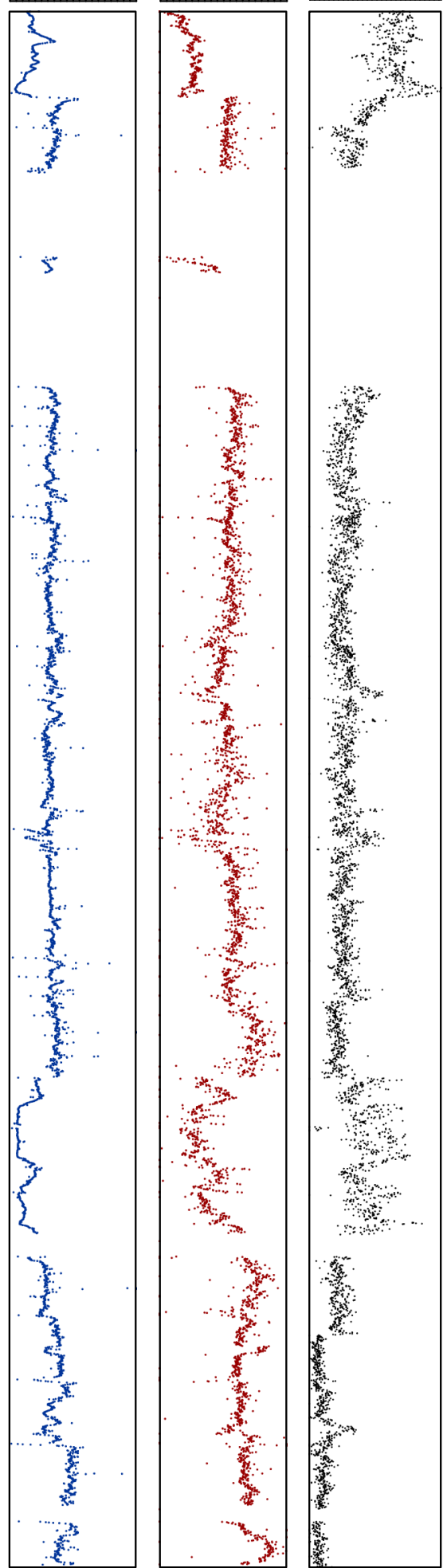


Figure F6 (continued). C. Hole U1419C. (Continued on next page.)

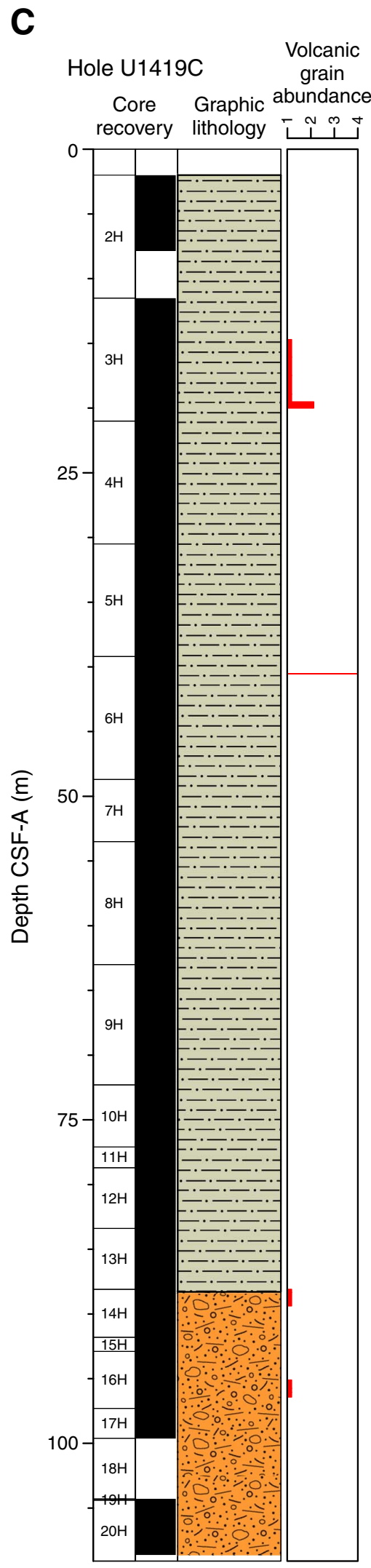

Unit description unit Age

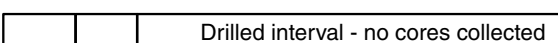

Dark greenish gray (10Y $4 / 1)$ to olive gray (5Y 4/2) diatom ooze extends from the top of Hole $\mathrm{C}$ to $5.7 \mathrm{~m}$ CSF-A. Two other intervals of ooze occur at 80.4 and $82.4 \mathrm{~m}$ CSF-A. Dark gray (N 4) to dark greenish gray (10Y 4/1) mud with lonestones is the major lithology occurring beneath $5.7 \mathrm{~m}$. The clast composition is diverse including argillite, siltstone, sandstone, and granitoids. Subordinate lithologies include dark gray (N 4) interbedded silt and mud, and interbedded sand and mud, with thin
sand beds up to $1 \mathrm{~cm}$ with sharp lower sand beds up to $1 \mathrm{~cm}$ with sharp lower
contacts. Intervals of ash are dispersed within the mud. Articulated bivalves and fragments occur in Core 3.

Dark gray (N 4) to very dark gray (N 3) muddy clast-rich diamict is interbedded with clast-poor diamict, mud with dispersed clasts, and thin coarse sand dispersed clasts, and thin coarse sand
beds. Clast-rich diamict is interstratified with mud beds. Diamict contains sub-rounded to sub-angular granules and pebbles of diverse composition including siltstone, sandstone, argillite, greenstone, granitoids, and diorite.
Magnetic susceptibility

(IU)

GRA bulk density $\left(\mathrm{g} / \mathrm{cm}^{3}\right)$

Color reflectance

웅 웅 \&

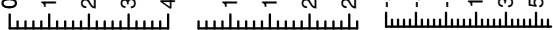
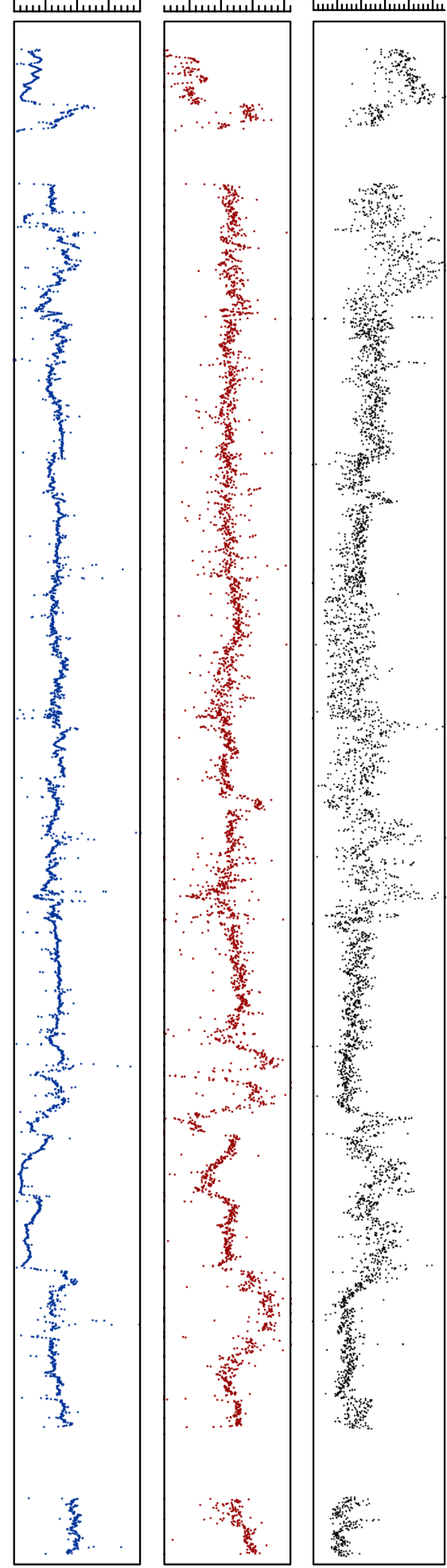
Figure F6 (continued). D. Hole U1419D. (Continued on next page.)

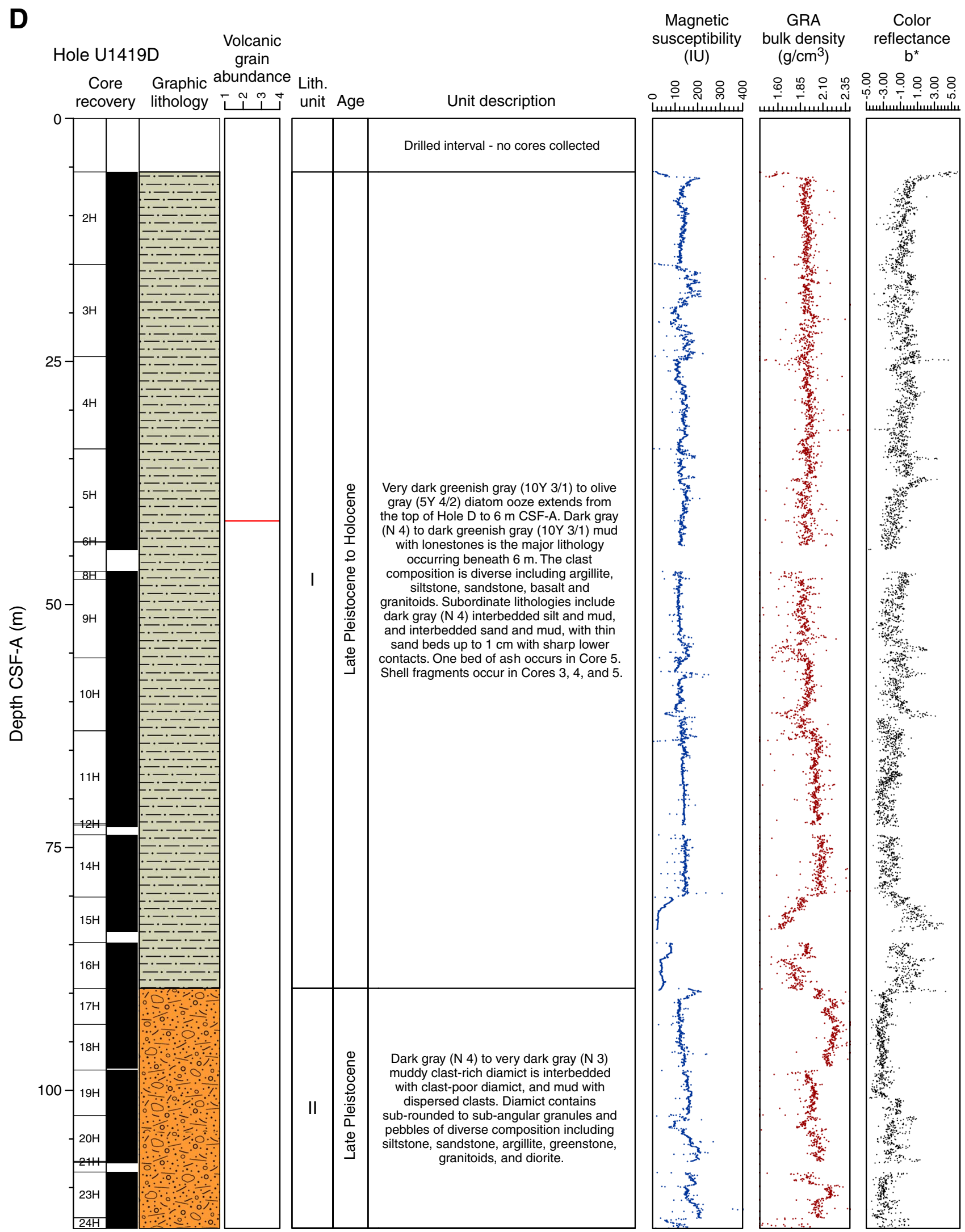


Figure F6 (continued). E. Hole U1419E.

E

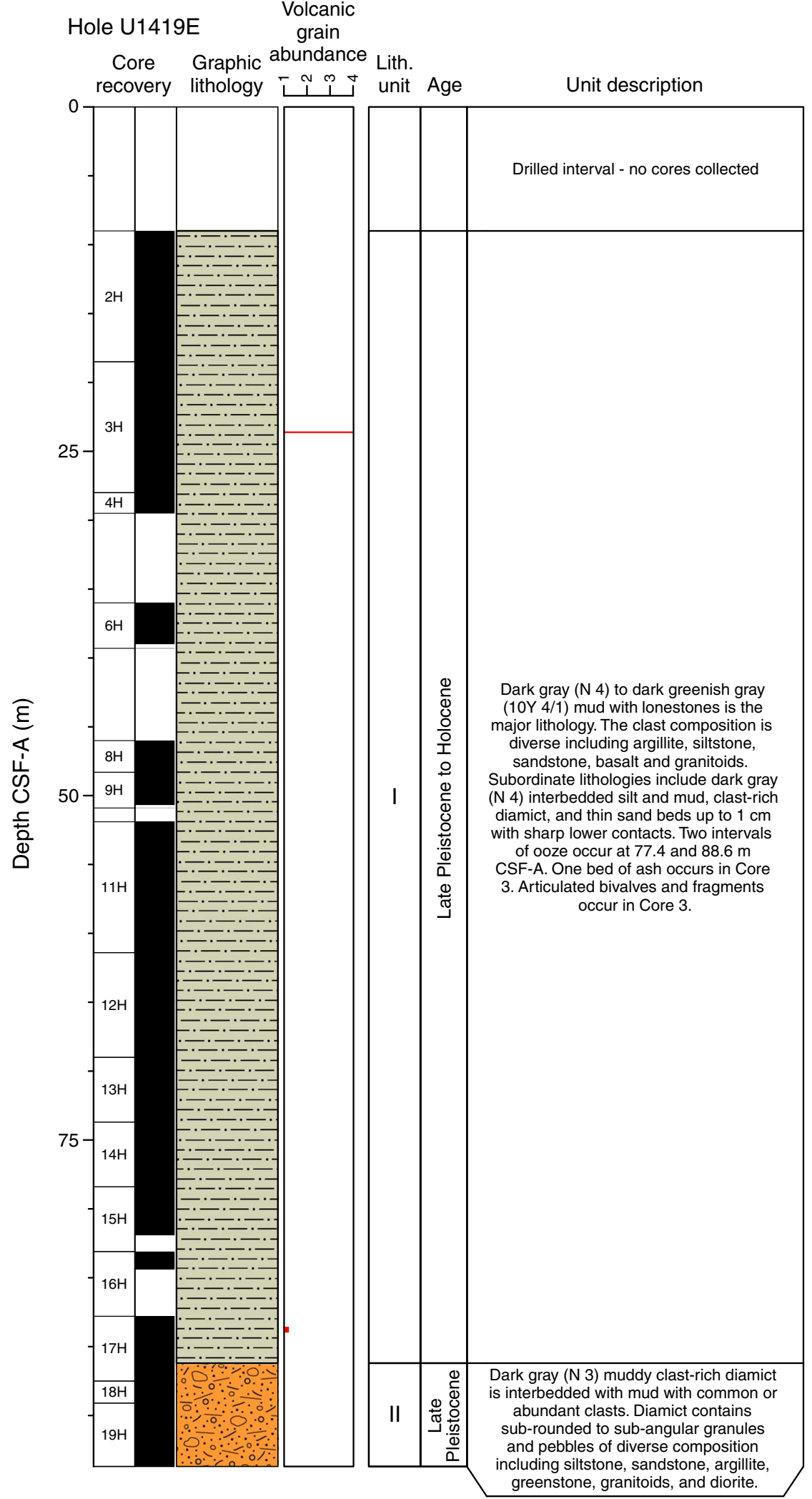

Magnetic susceptibility

(IU)

GRA bulk density

$\left(\mathrm{g} / \mathrm{cm}^{3}\right)$

Color

으 \& \& \& \& 윰

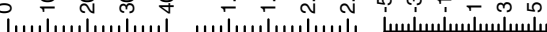

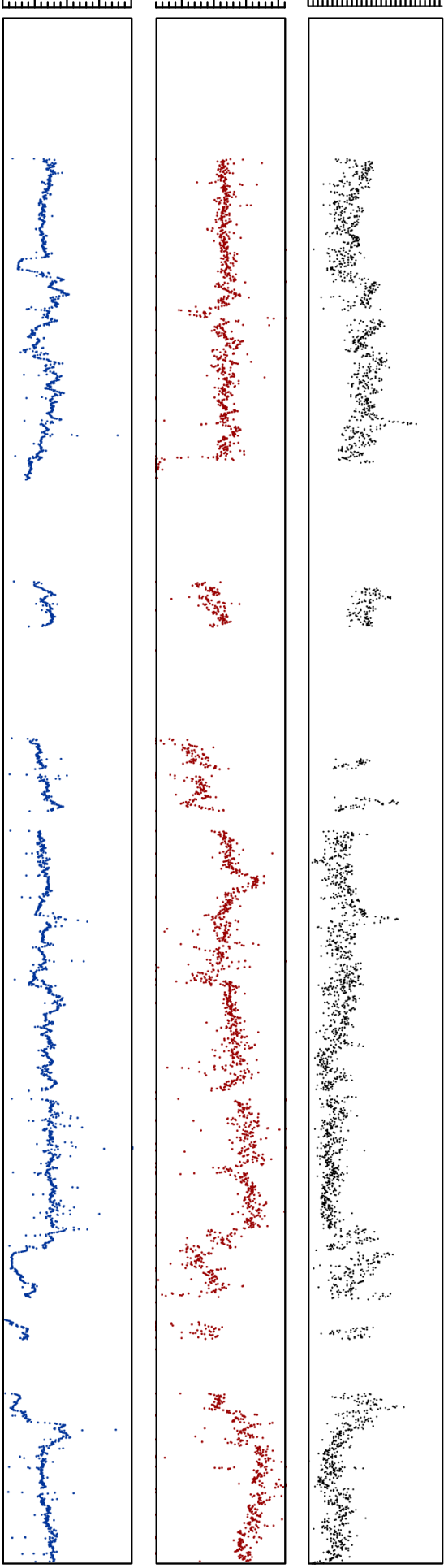


Figure F7. Examples of lithofacies, Site U1419. A. Dark gray (N 4) massive mud without lonestones (Facies F1b; interval 341-U1419A-8H-2, 51-57 cm). B. Dark gray (N 4) massive mud with lonestones (Facies F1a; interval 341-U1419A-6H-3, 94-101 cm). C. Interbedded silt and mud (Facies F2b; interval 341-U1419B-7H-4, 28-49 $\mathrm{cm}$ ). D. Sand (Facies F3a; interval 341-U1419C-6H-1, 23-30 cm). E. Clast-poor diamict (Facies F4e; interval 341U1419B-14H-3, 26-34 cm). F. Interstratified clast-rich diamict (Facies F4f; interval 341-U1419E-13H-2, 16-47 $\mathrm{cm}$ ). G. Diatom ooze (Facies F5a; interval 341-U1419A-8H-3, 94-100 cm). H. Volcanic ash at 7-10 cm (Facies F6; interval 341-U1419D-5H-6, 4-11 cm).

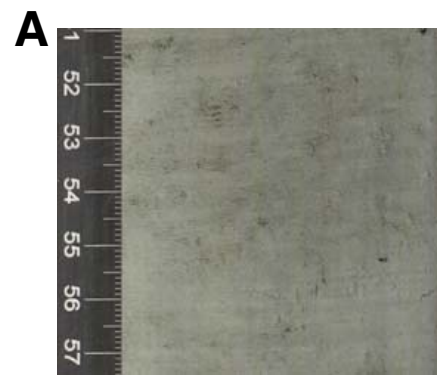

C

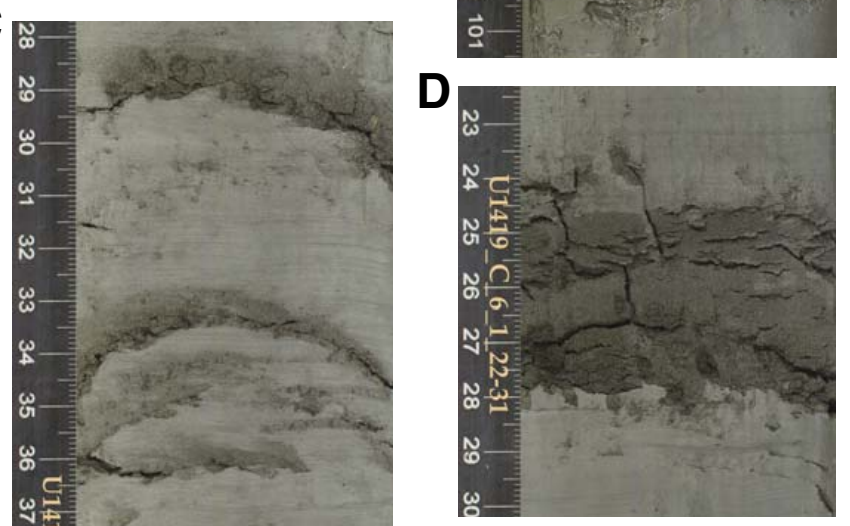

E

B
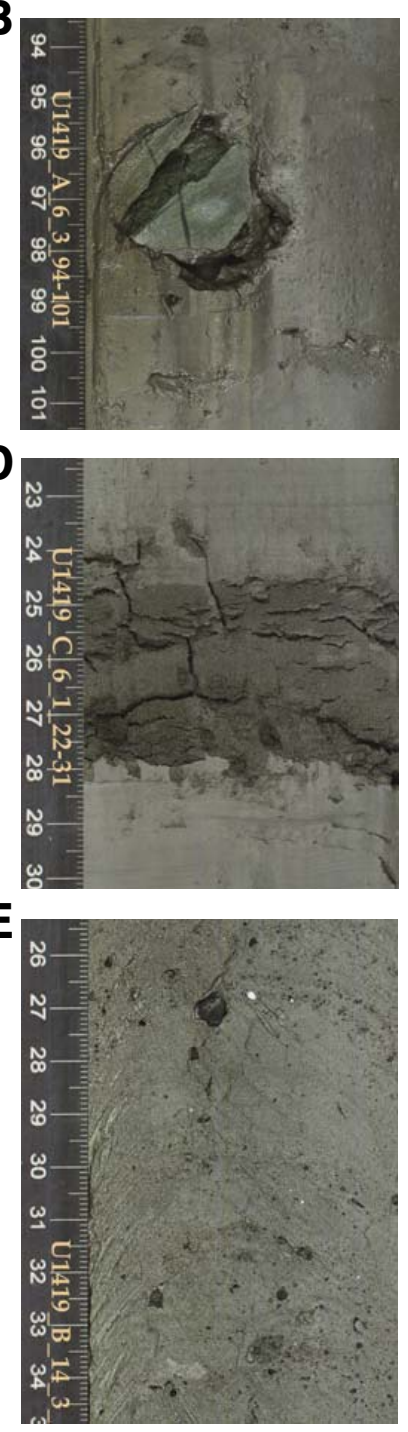

$\mathbf{F}$

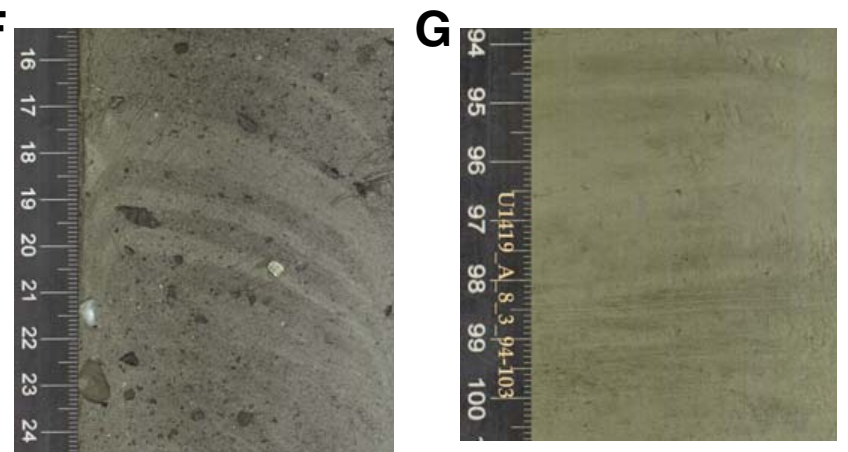

H

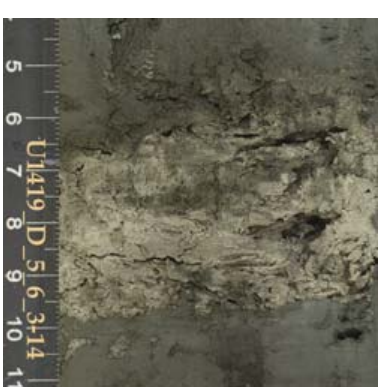


Figure F8. Examples of lonestones, diamict clasts, and fossils, Site U1419. A. Siltstone (interval 341-U1419A17H-1, 96-99 cm). B. Sandstone (interval 341-U1419E-2H-4, 125-128 cm). Note the bedding within the clast. C. Basalt breccia (interval 341-U1419A-9H-4, 103-106 cm). D. Mica schist (interval 341-U1419A-17H-2, 45-48 $\mathrm{cm}$ ). E. Granite (interval 341-U1419B-6H-CC, 15-24 cm). F. Chert (interval 341-U1419C-16H-1, 56-65 cm). G. Bivalve (interval 341-U1419D-8H-1-CC). Vertical scale is in millimeters.
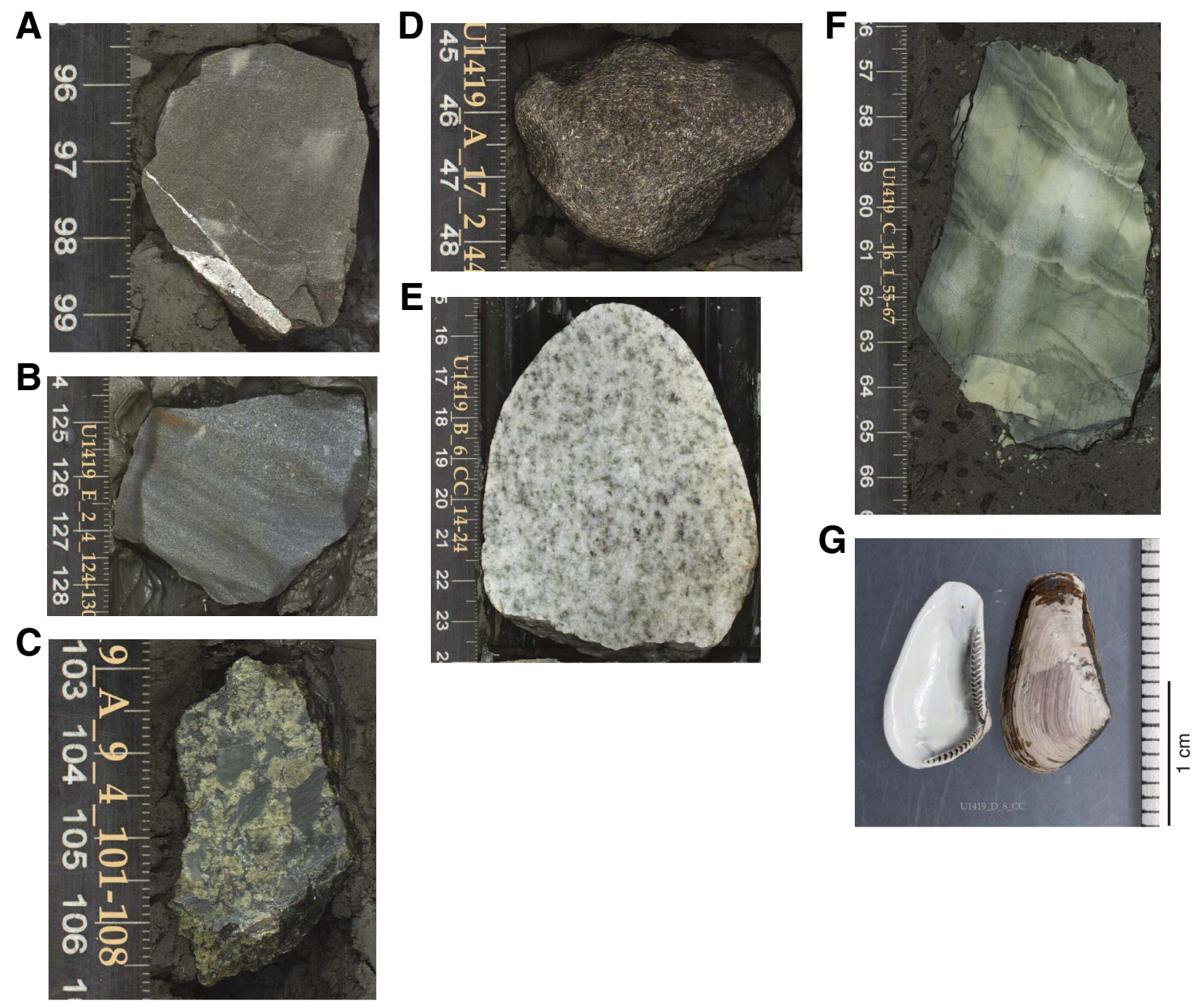
Figure F9. Schematic diagram of lithostratigraphic units and major lithologies, Site U1419. Clasts per meter column indicates number of lonestones per meter. With the exception of lonestone counts, downcore profiles represent the occurrence of a described lithologic feature. Data from Holes U1419A-U1419E were combined to produce these profiles. Because of low core recovery (average $=18 \%$ ) deeper than $118 \mathrm{~m}$ CCSF-B, we do not show the distribution of lithostratigraphic features beneath this depth. Because of the large abundance of clasts deeper than $70 \mathrm{~m}$ CCSF-B, individual clasts (>2 $\mathrm{mm}$ ) were not counted.

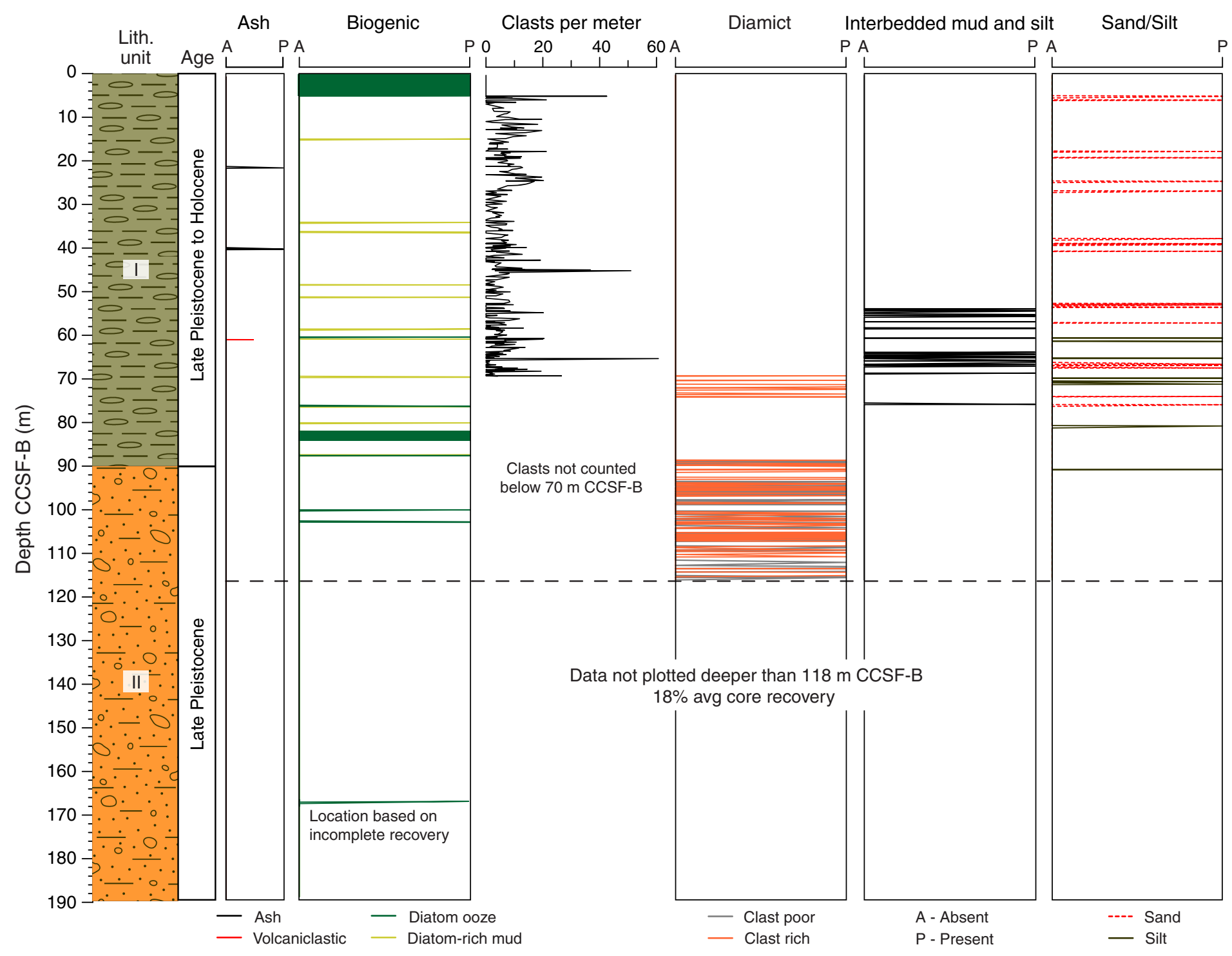


Figure F10. Ternary diagram showing average abundance of the main lithology types of clasts larger than $2 \mathrm{~mm}$ in Holes U1419A-U1419E and the average for Site U1419. M = metamorphic, I = igneous, S = sedimentary.

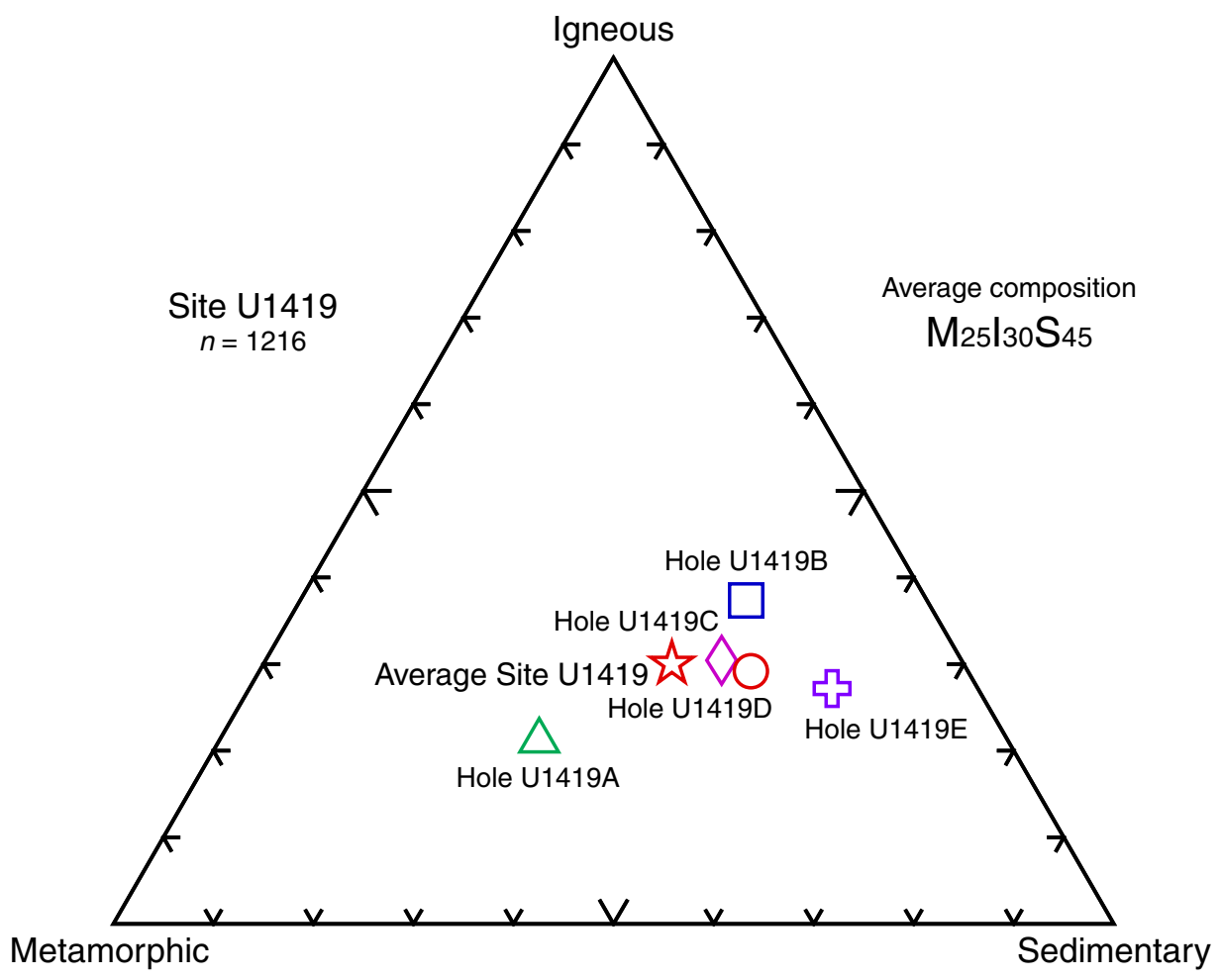


Figure F11. A. X-ray powder diffraction patterns, Hole U1419A. Bulk mineralogy is nearly constant downhole, although minor changes in intensity occur for various peaks. (Continued on next page.)

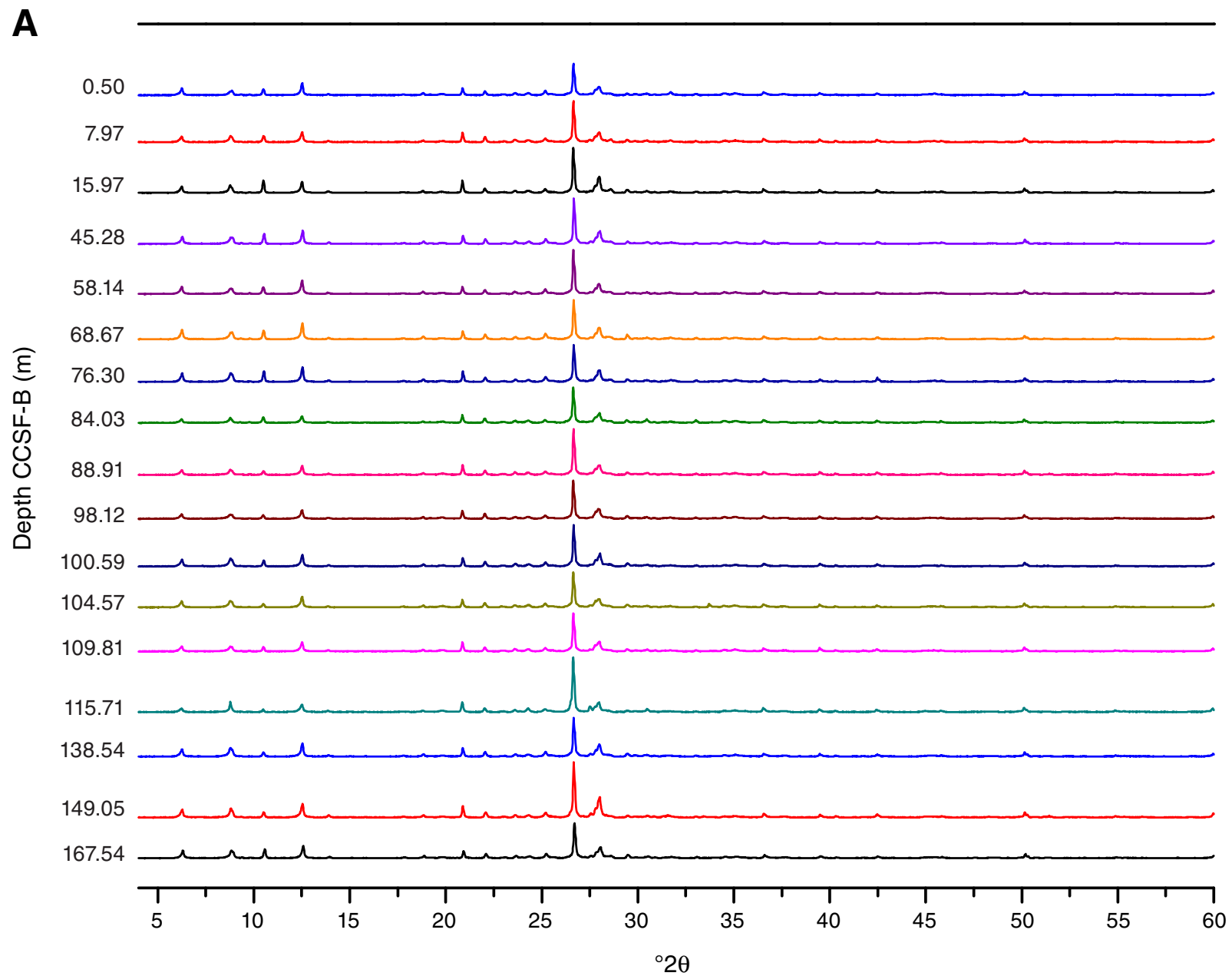


Figure F11 (continued). B. Comparative X-ray diffraction patterns from $4^{\circ}$ to $24^{\circ} 2 \theta$, Site U1419. Scans show the downhole samples before (left) and after (right) glycolization treatment.

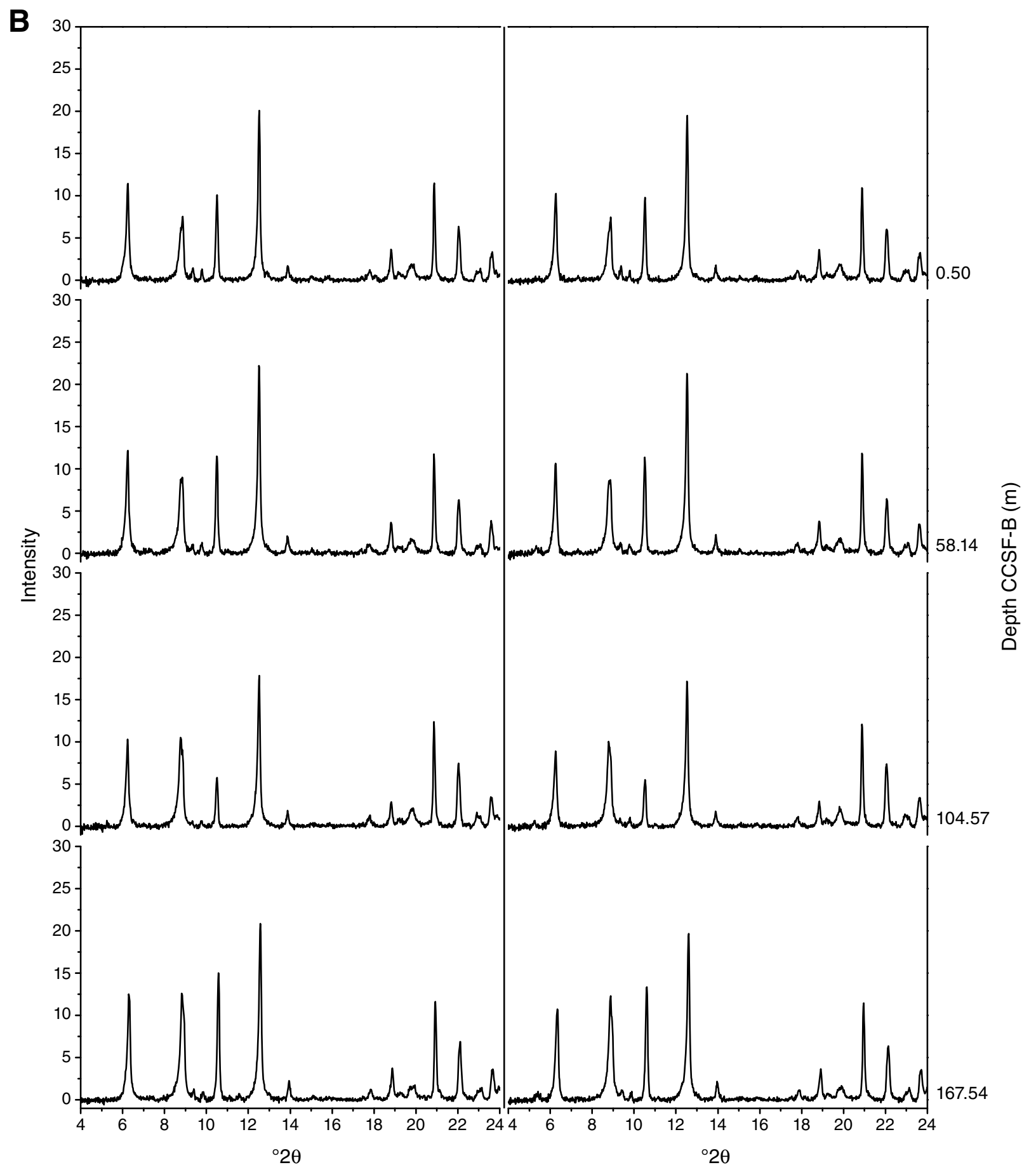


Figure F12. Abundance and preservation of diatoms, radiolarians, and planktonic and benthic foraminifers, Site U1419. Abundance: $\mathrm{D}=$ dominant, $\mathrm{A}=$ abundant, $\mathrm{C}=$ common, $\mathrm{F}=\mathrm{few}, \mathrm{R}=$ rare, $\mathrm{P}=$ present $\mathrm{B}=\mathrm{barren}$. Preservation: $\mathrm{VG}=$ very good, $\mathrm{G}=$ good, $\mathrm{M}=$ moderate, $\mathrm{P}=$ poor.

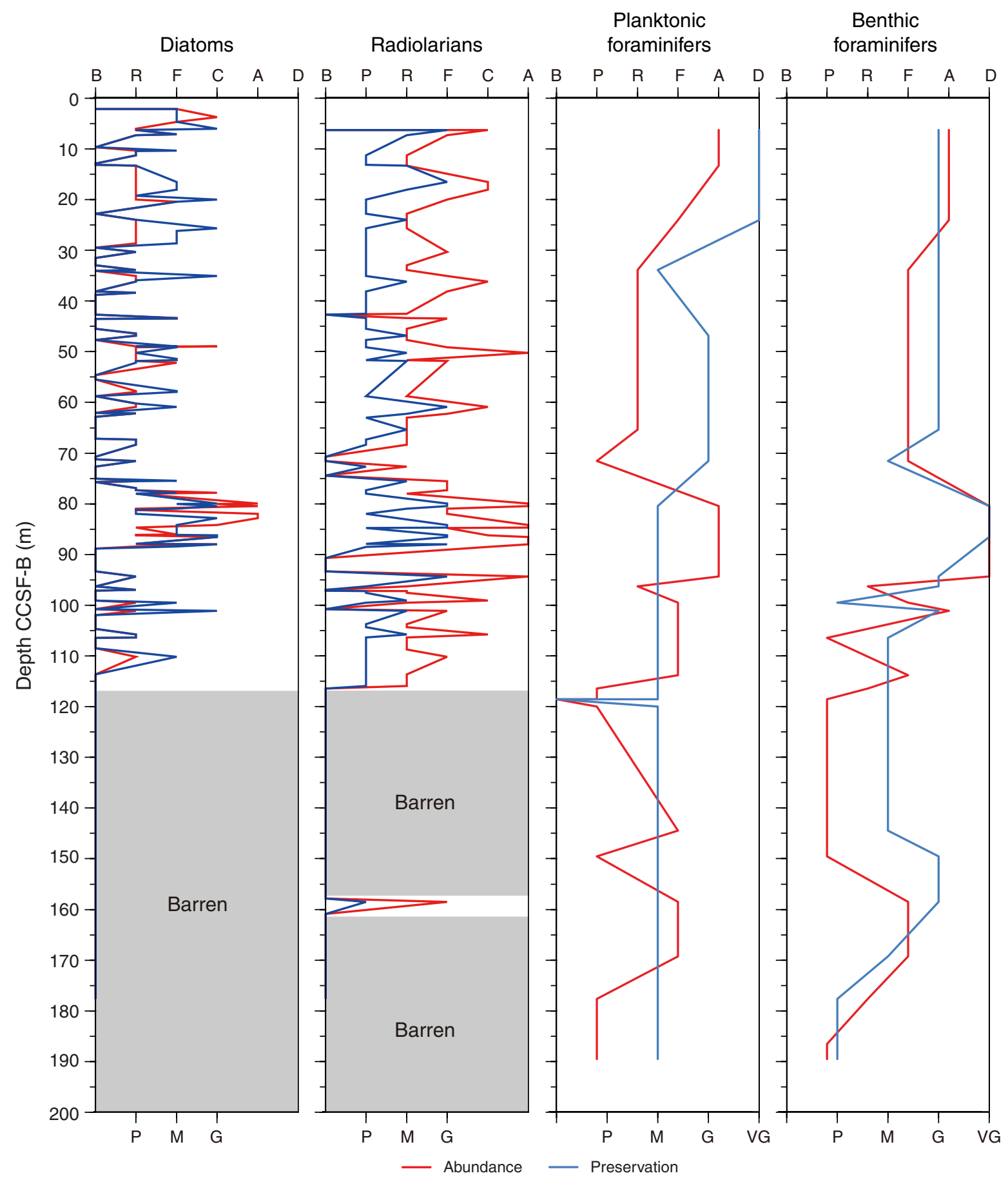


Figure F13. Diatom and radiolarian paleoenvironmental indicators, Site U1419. Abundance: A = abundant, $\mathrm{C}$ $=$ common, $\mathrm{F}=$ few, $\mathrm{R}=$ rare, $\mathrm{X}=$ present, $\mathrm{P}=$ present.

Diatoms

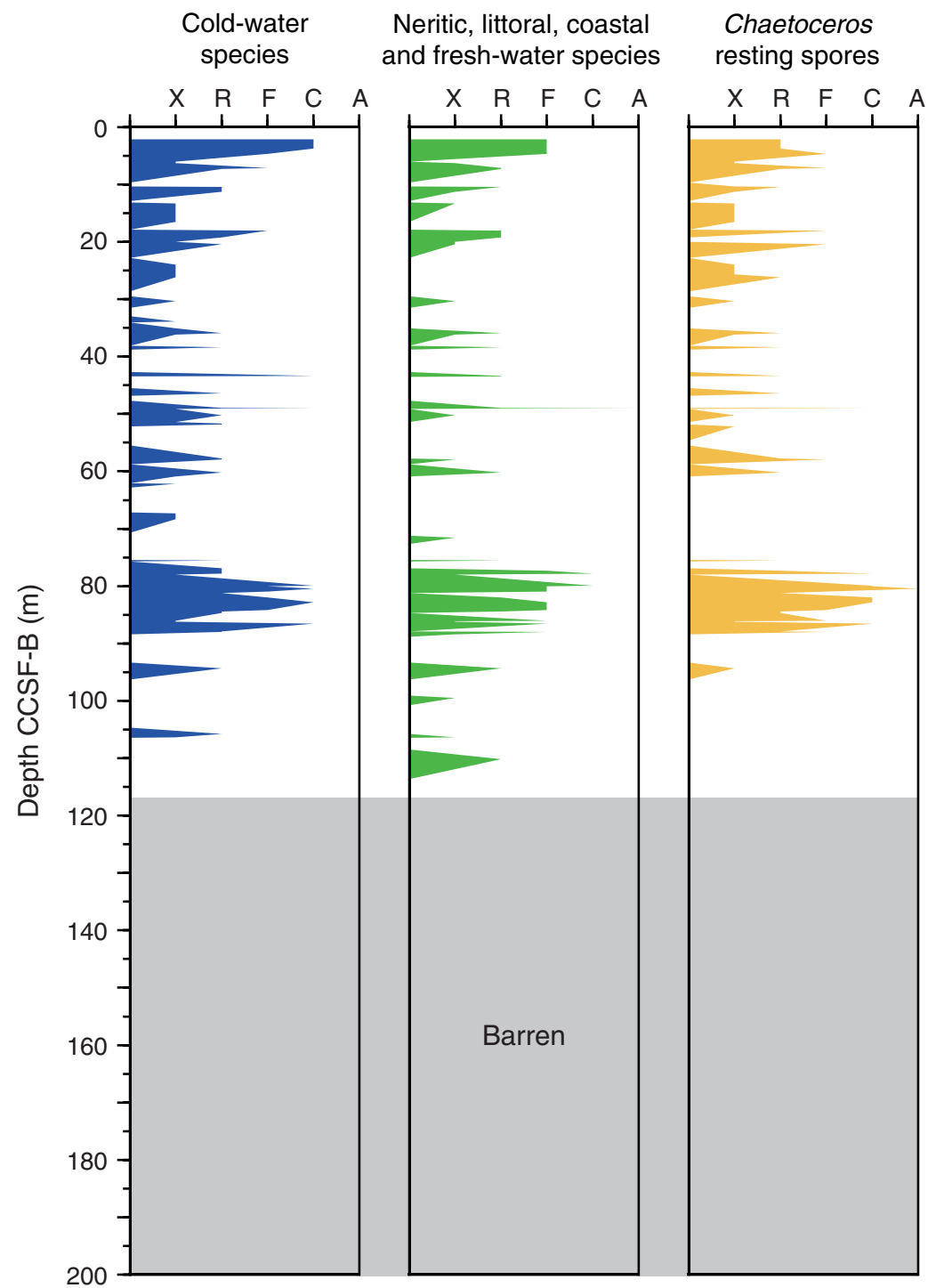

Radiolarians

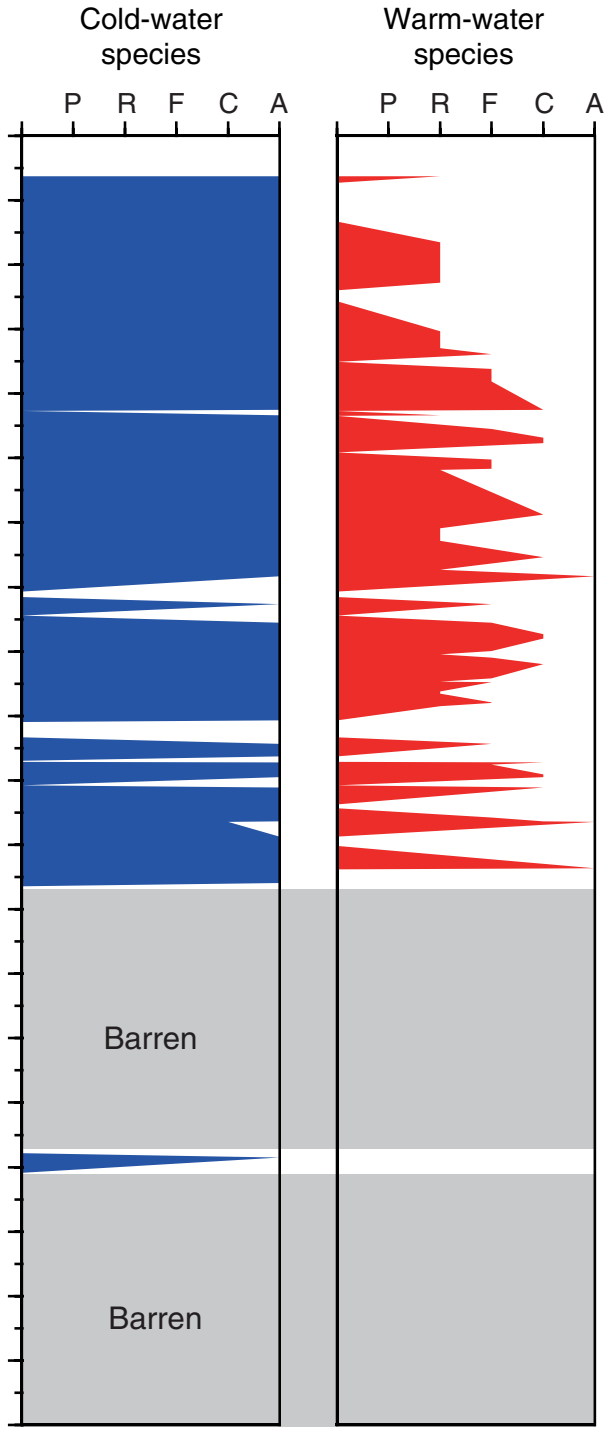


Figure F14. Major changes in planktonic foraminiferal fauna in Hole U1419A, illustrated using rank relative abundance of Globigerina umbilicata and Globigerina bulloides integrate and the percent abundance of Neogloboquadrina pachyderma (dextral). Abundance: $\mathrm{D}=$ dominant, $\mathrm{A}=$ abundant, $\mathrm{F}=$ few, $\mathrm{R}=$ rare, $\mathrm{P}=$ present.

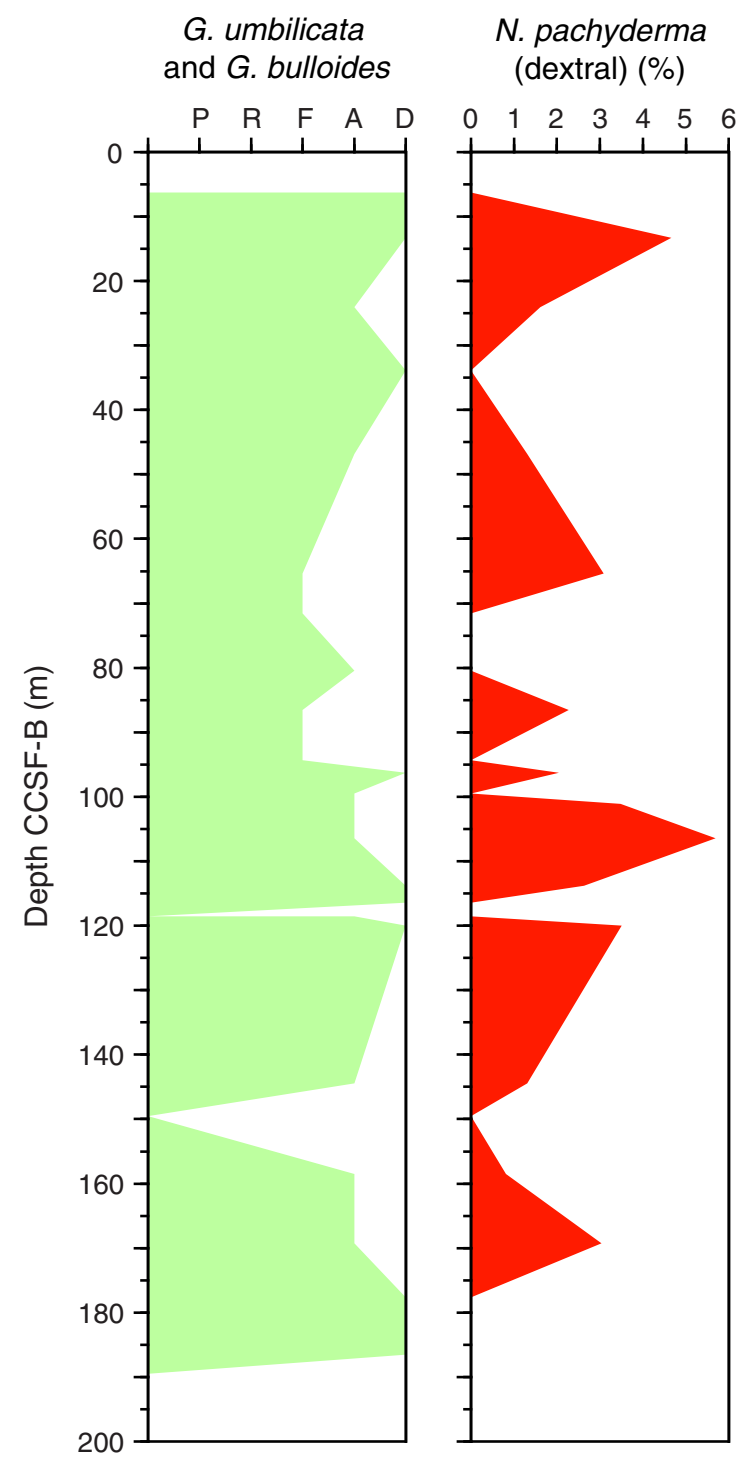


Figure F15. Major changes in benthic foraminiferal fauna Hole U1419A, illustrated using rank relative abundance of Elphidium spp., Eubuliminella exilis, Nonionella labradorica, and Epistominella pacifica. Abundance: $\mathrm{D}=$ dominant, $\mathrm{A}=$ abundant, $\mathrm{F}=$ few, $\mathrm{R}=$ rare, $\mathrm{P}=$ present.

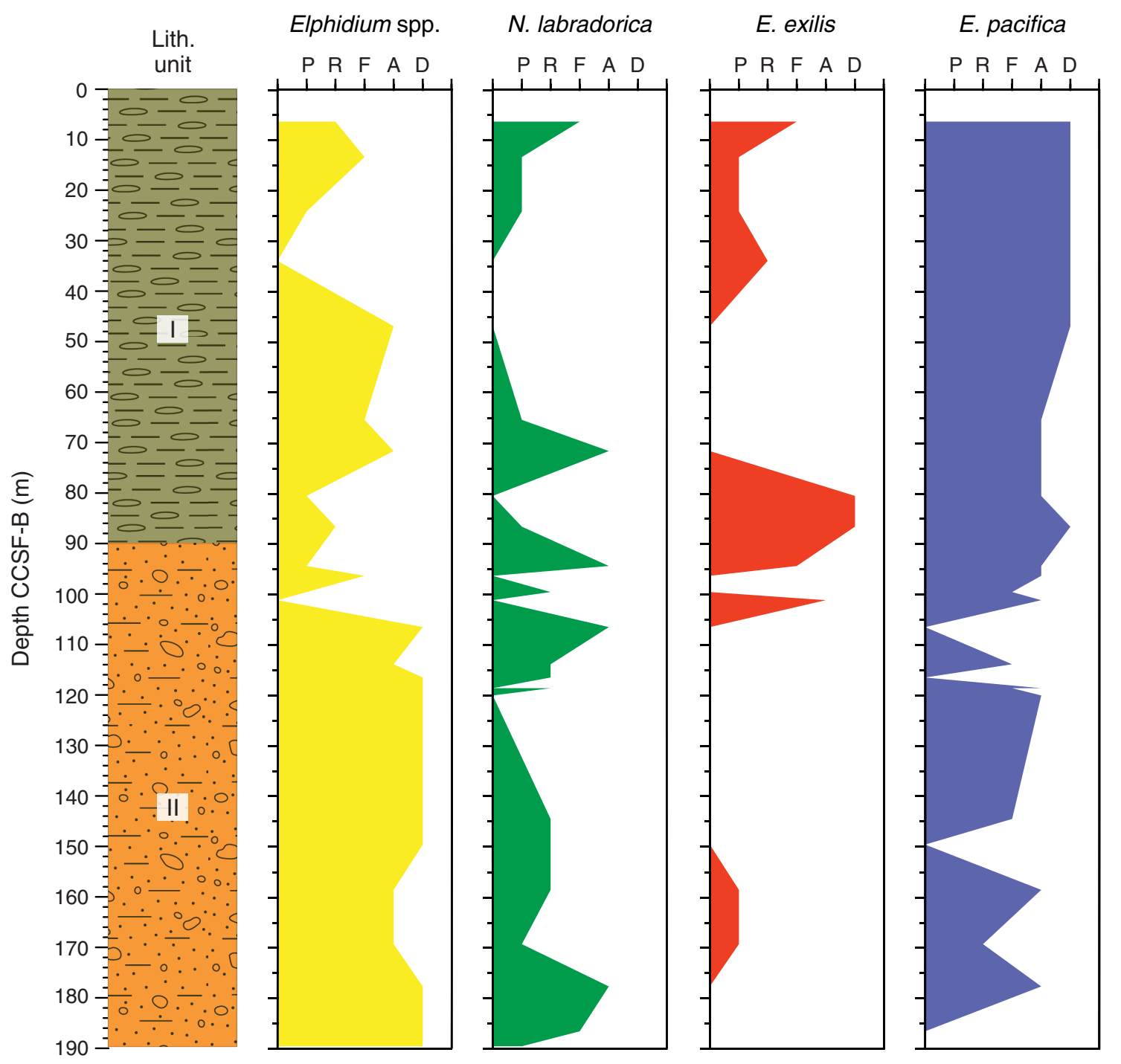


Figure F16. Magnetic susceptibility data for the interval of the continuous splice in Holes U1419A-U1419E and the splice record. Gray boxes = intervals used to construct the splice, dashed vertical lines with question marks = intervals where tie points should be treated with caution (see text for details). A. 0-50 m CCSF-A. (Continued on next page.)

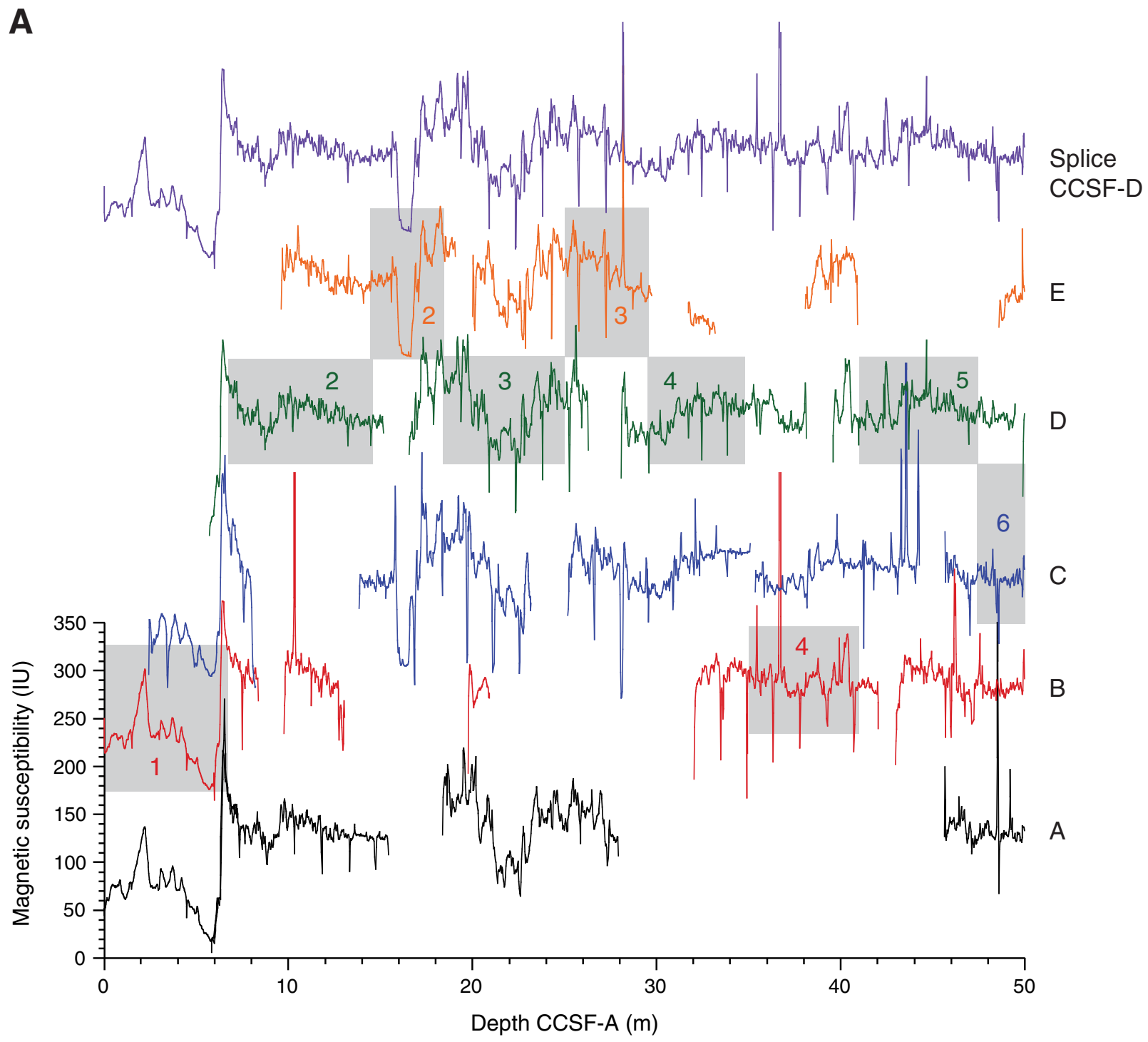


Figure F16 (continued). B. 50-120 m CCSF-A.

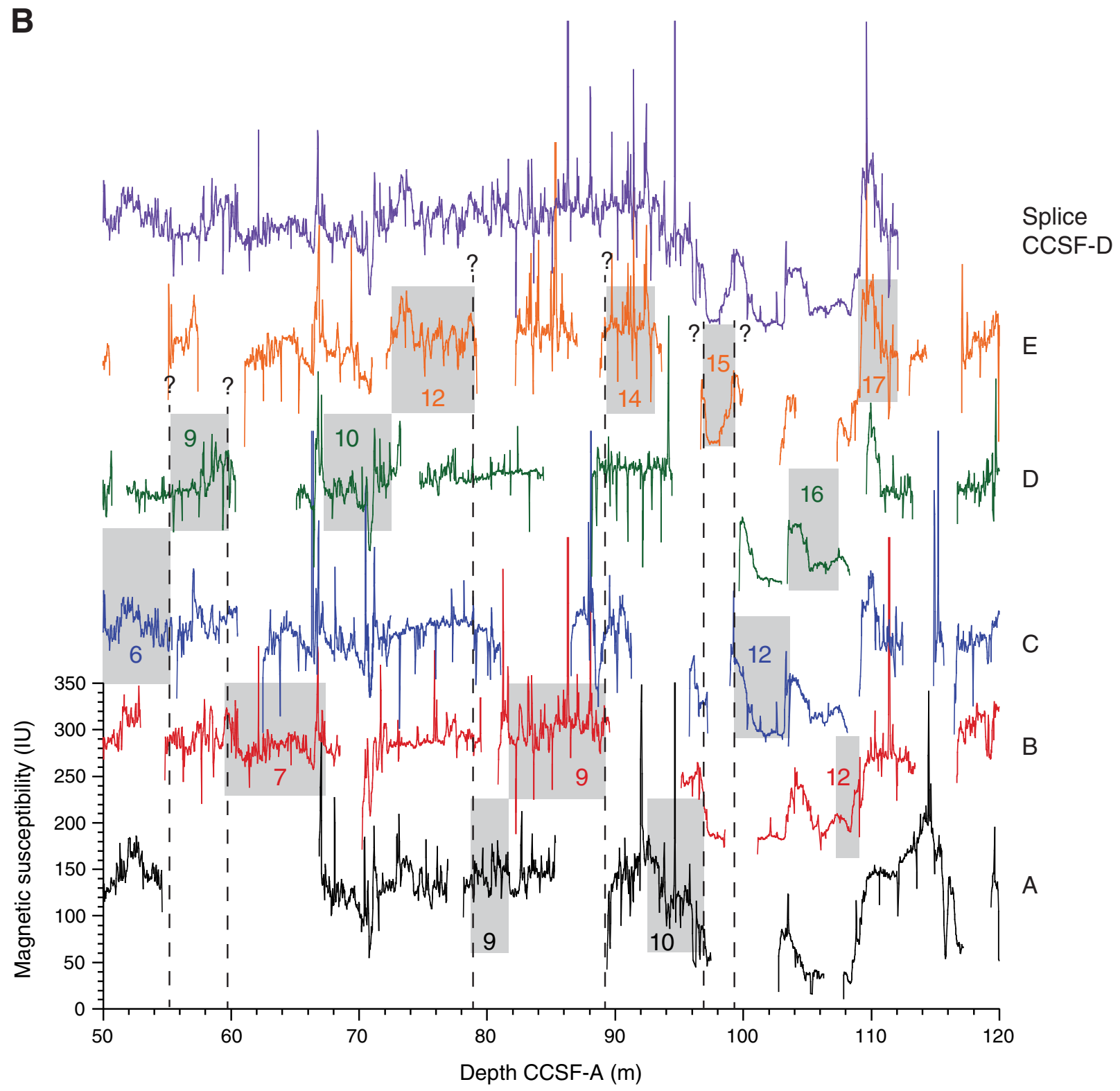


Figure F17. GRA bulk density data for the interval of the continuous splice in Holes U1419A-U1419E and the splice record. Gray boxes = intervals used to construct the splice, dashed vertical lines with question marks = intervals where tie points should be treated with caution (see text for details). A. 0-50 m CCSF-A. (Continued on next page.)

A

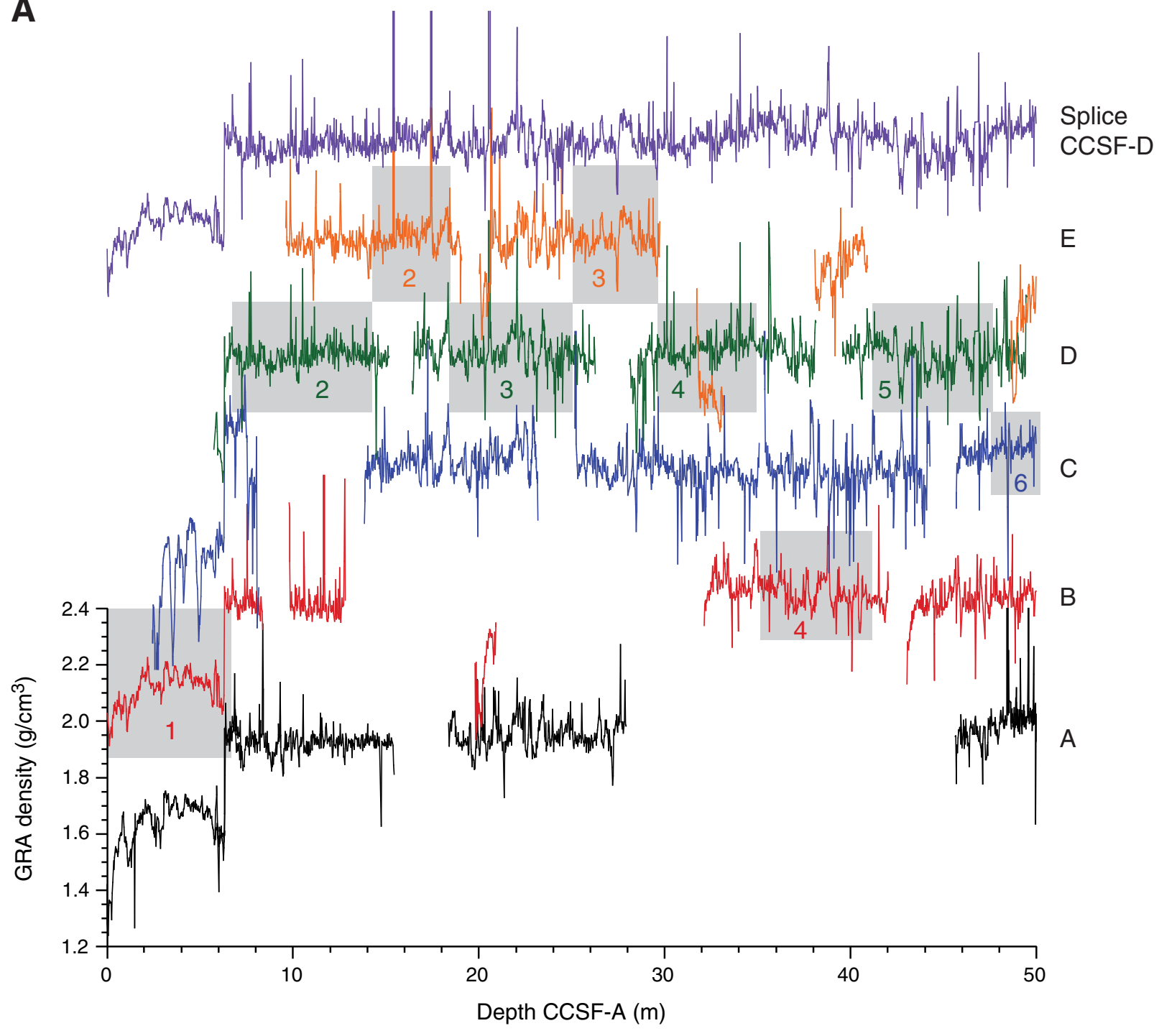


Figure F17 (continued). B. 50-120 m CCSF-A.

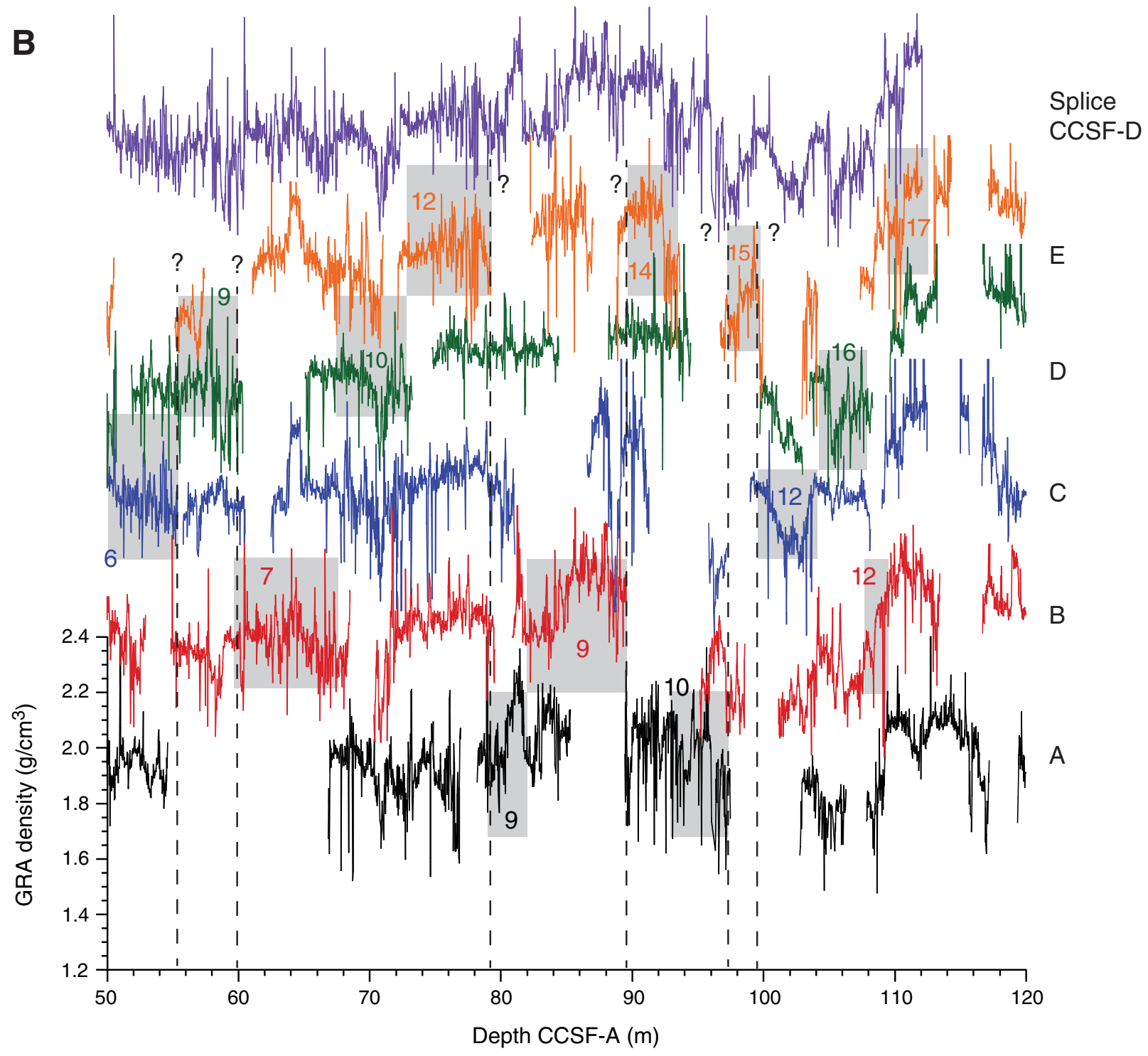


Figure F18. Affine values, Holes U1419A-U1419E. Equations denote the relationship between the affine values and core top depth for each of the three segments and the line of best fit (black line).

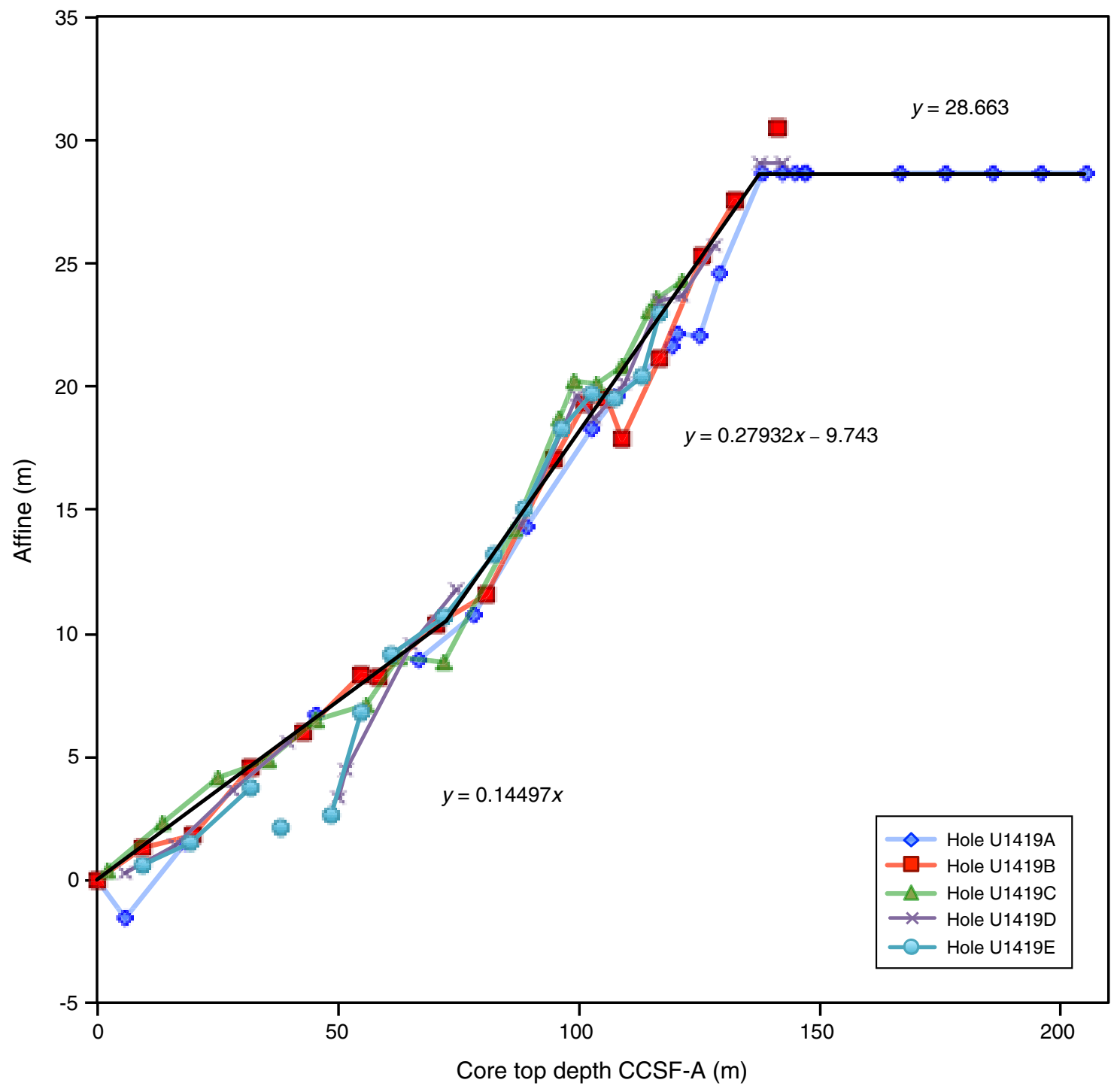


Figure F19. Dissolved chemical concentrations and headspace gas, Hole U1419A. A. Alkalinity. B. pH. C. Sulfate. D. Ammonium. E. Bromide. F. Methane. G. Silica. H. Salinity. I. Chloride. J. Sodium. Full details of Lithology column are shown in Figure F9 (see "Lithostratigraphy").

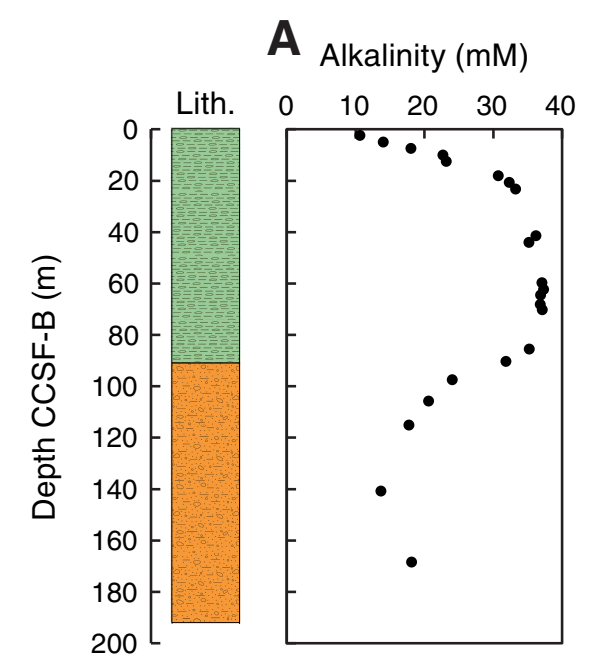

$$
\text { B } \quad \mathrm{pH} \quad \text { C Sulfate }(\mathrm{mM})
$$

$\mathbf{D}_{\text {Ammonium (mM) }}$

\section{E Bromide (mM)}
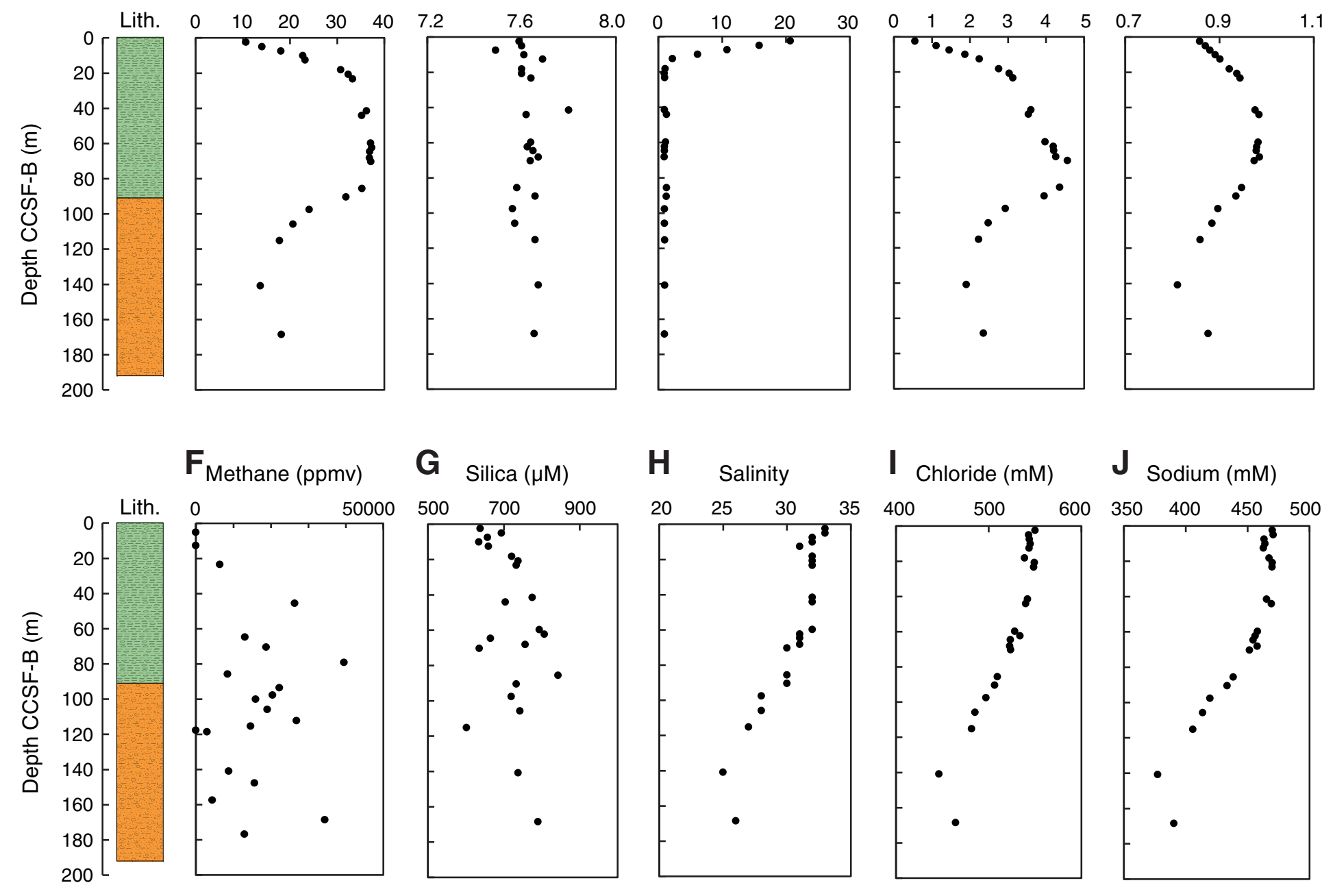

I Chloride (mM)

J Sodium (mM)
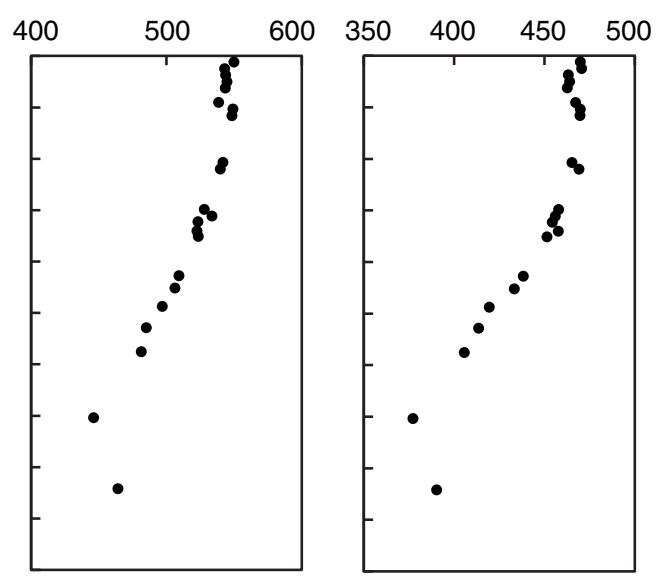
Figure F20. Dissolved chemical concentrations, Hole U1419A. A. Calcium. B. Potassium. C. Magnesium. D. Lithium. E. Boron. F. Barium. G. Strontium. H. Iron. I. Manganese. F. Phosphate. Full details of Lithology column are shown in Figure F9 (see "Lithostratigraphy").

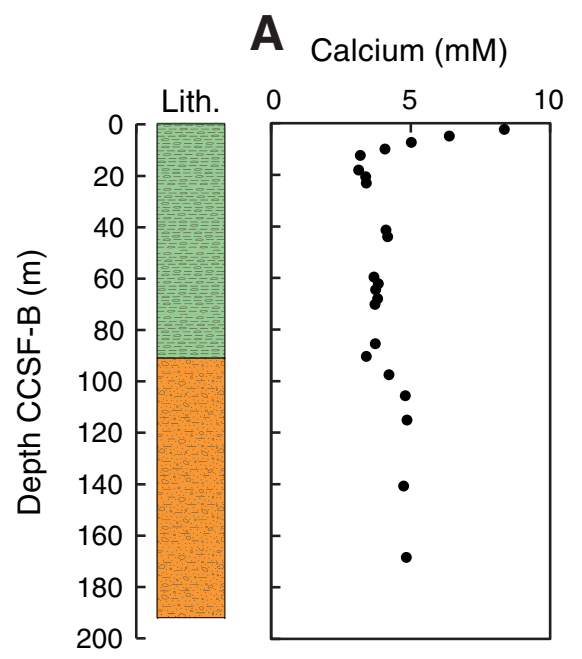

$\mathbf{B}_{\text {Potassium (mM) }}$

C Magnesium (mM)

D Lithium $(\mu \mathrm{M})$

E Boron $(\mu \mathrm{M})$
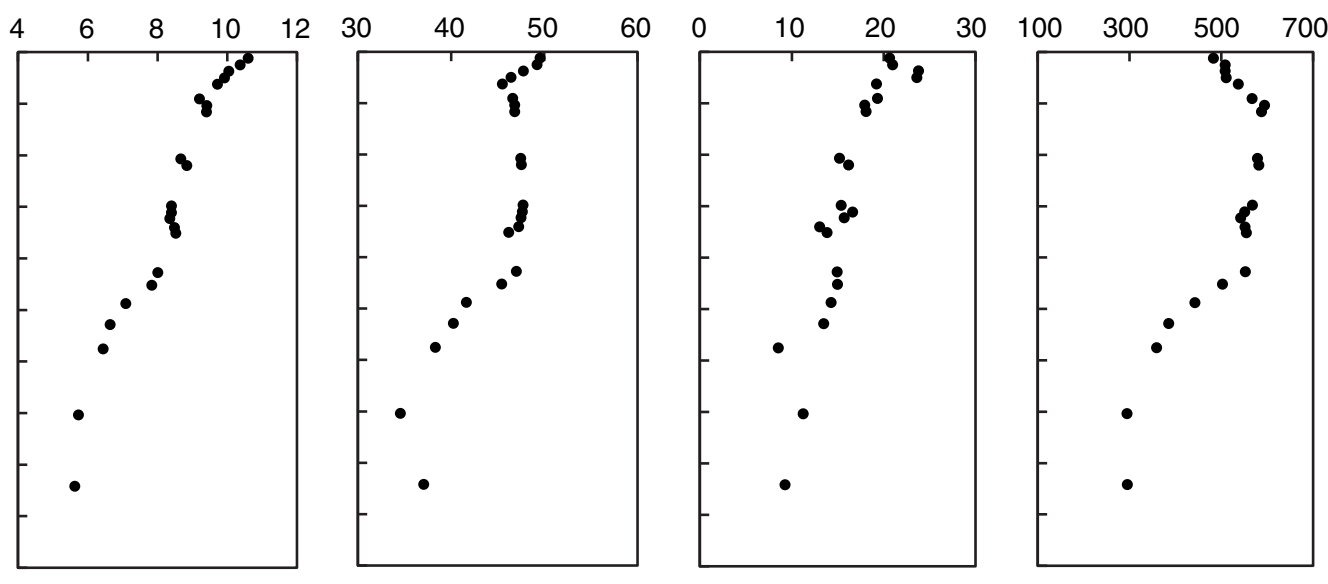

F Barium $(\mu \mathrm{M})$

G Strontium $(\mu \mathrm{M})$

H Iron ( $\mu \mathrm{M})$

I Manganese $(\mu \mathrm{M})$

J Phosphate $(\mu \mathrm{M})$
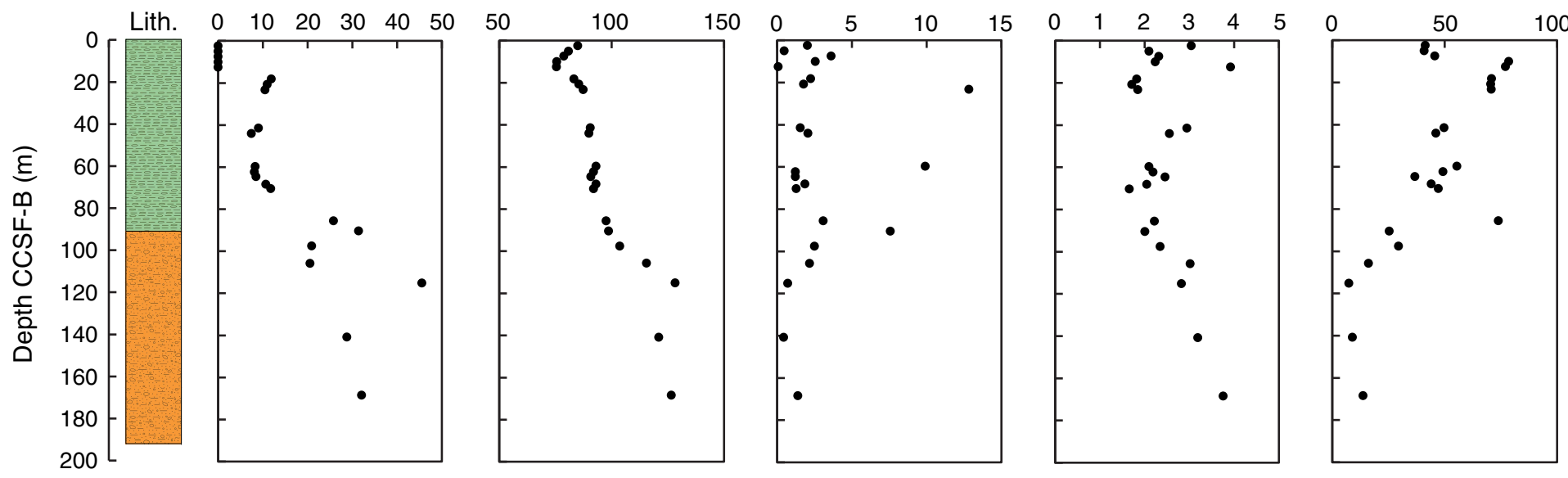
Figure F21. Solid-phase chemical parameters, Hole U1419A. A. Total organic carbon (TOC). B. Total nitrogen (TN). C. TOC/TN ratio (C/N). D. $\mathrm{CaCO}_{3}$. E. Scatter plot of TOC vs. TN. The potential contribution of inorganic $\mathrm{N}$ to the TN signal is estimated where the linear regression line intercepts the $y$-axis, which is below 0 (e.g., Schubert and Calvert, 2001). Full details of Lithology column are shown in Figure F9 (see "Lithostratigraphy").
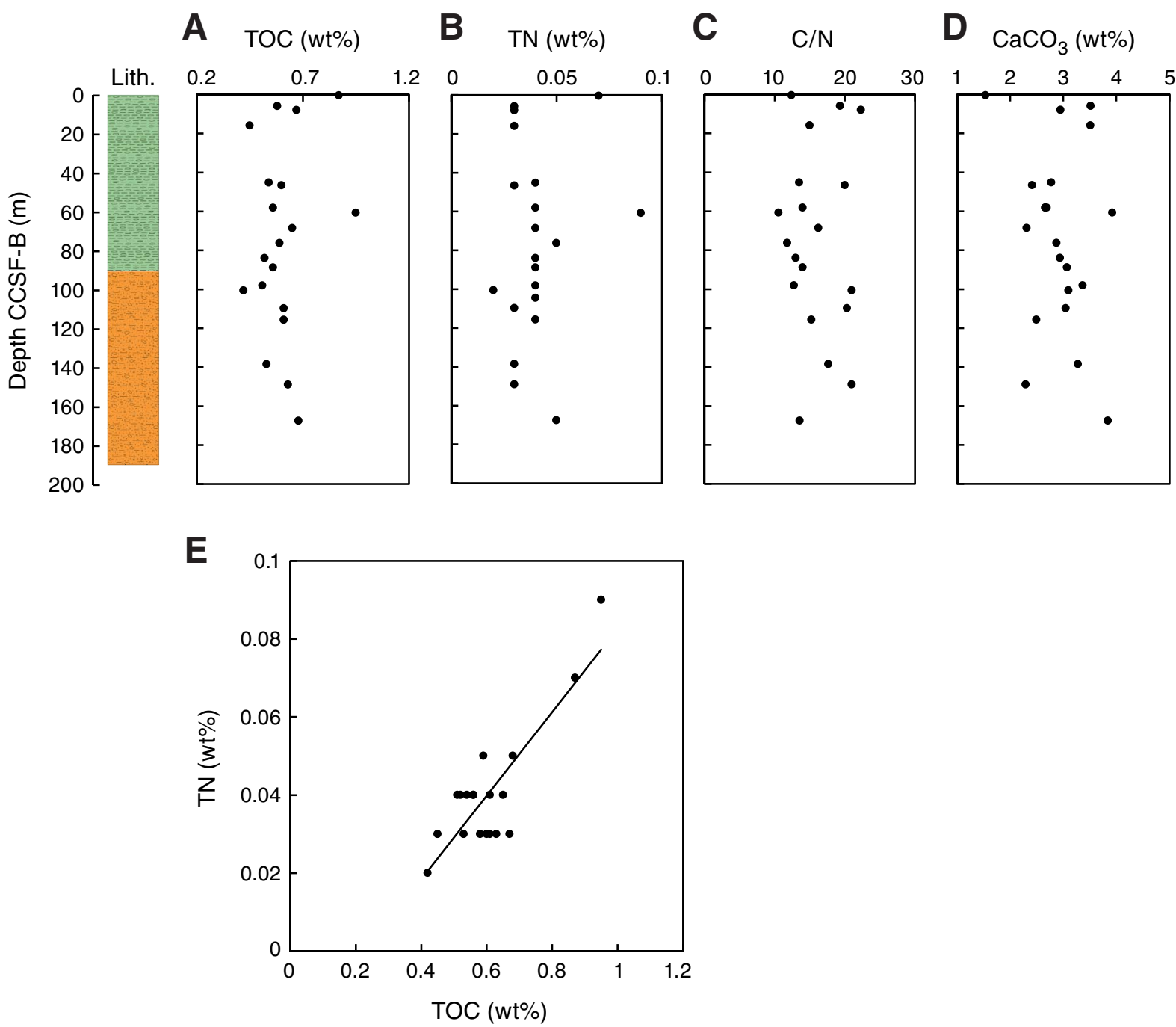
Figure F22. Physical properties measurements, Hole U1419A. WRMSL = Whole-Round Multisensor Logger, MS = magnetic susceptibility. MAD = moisture and density, GRA = gamma ray attenuation. NGR = natural gamma radiation.

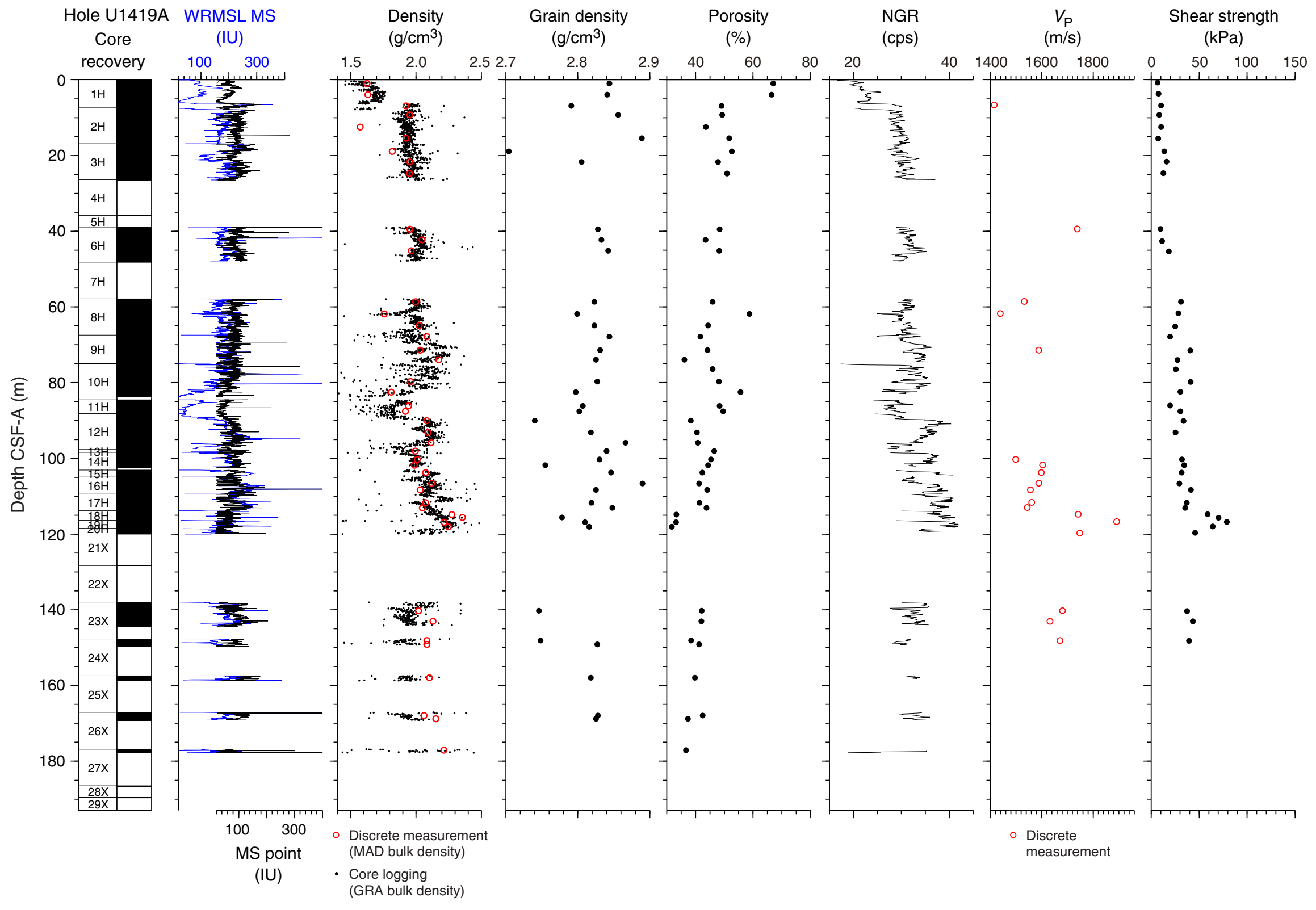


Figure F23. Physical properties measurements, Hole U1419B. WRMSL = Whole-Round Multisensor Logger, MS $=$ magnetic susceptibility. GRA = gamma ray attenuation. NGR = natural gamma radiation .
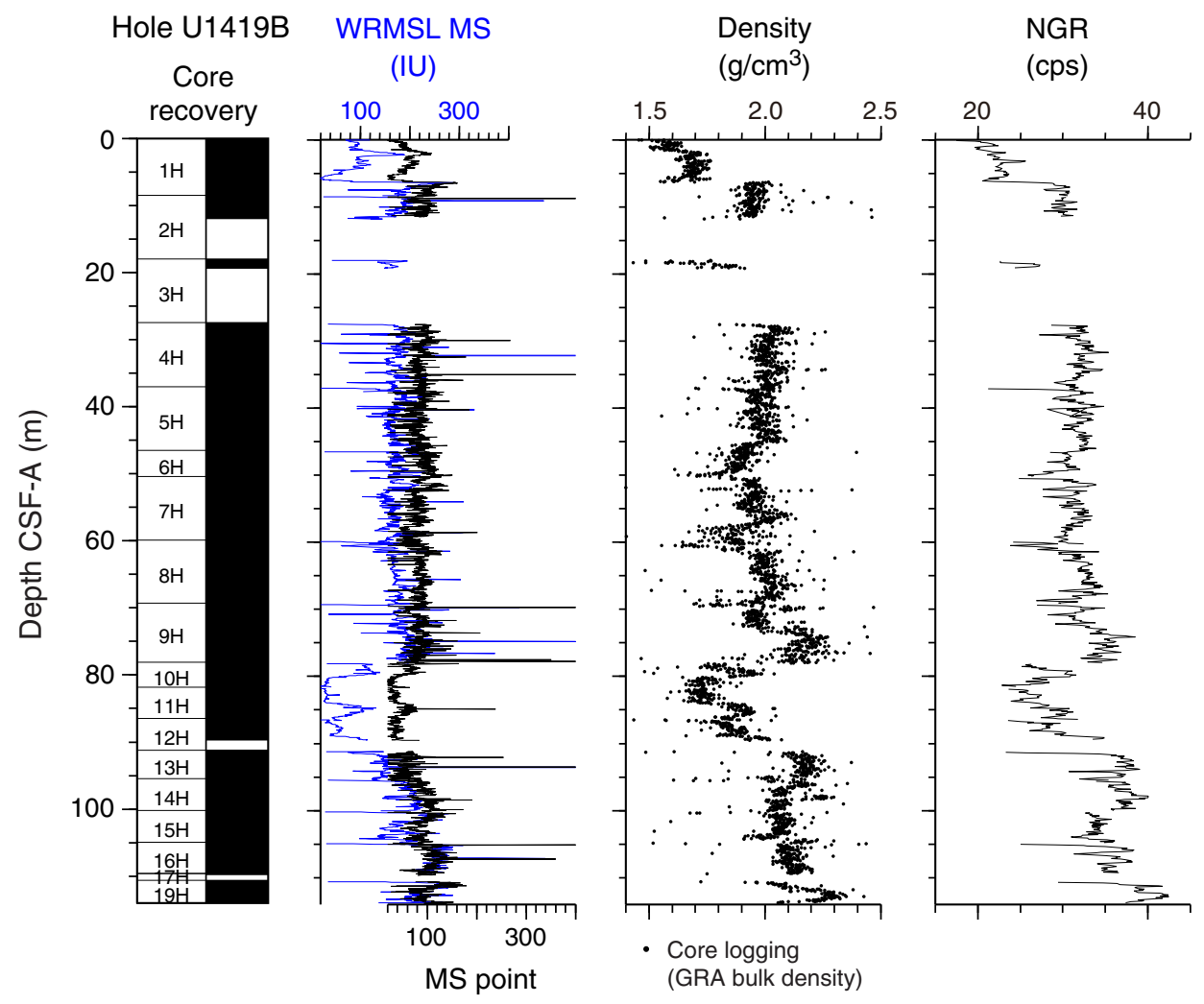

(IU) 
Figure F24. Physical properties measurements, Hole U1419C. WRMSL = Whole-Round Multisensor Logger, MS = magnetic susceptibility. GRA = gamma ray attenuation. NGR = natural gamma radiation .

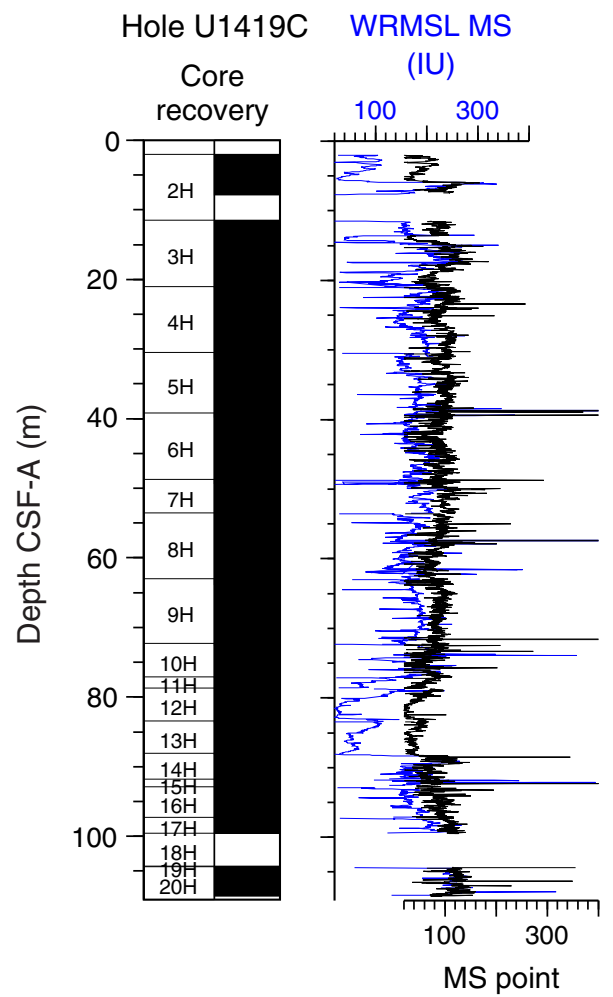

(IU)
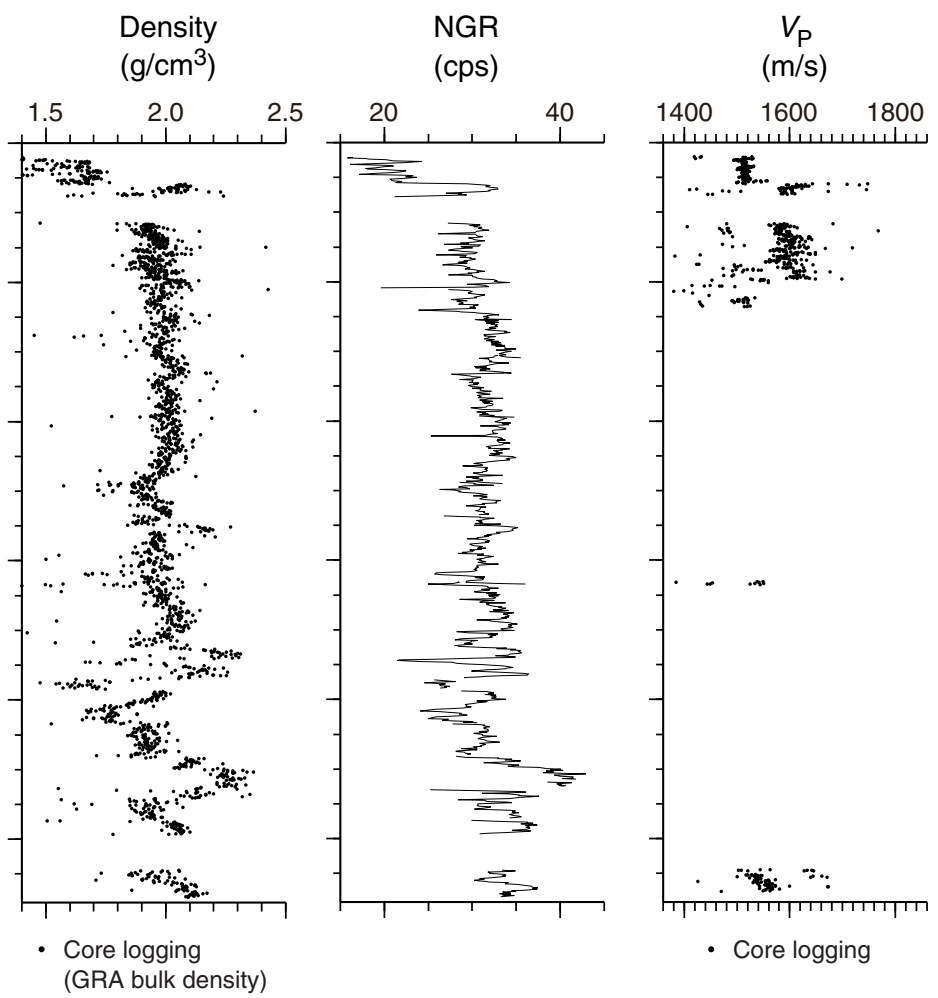
Figure F25. Physical properties measurements, Hole U1419D. WRMSL = Whole-Round Multisensor Logger, MS $=$ magnetic susceptibility. GRA = gamma ray attenuation. NGR = natural gamma radiation .

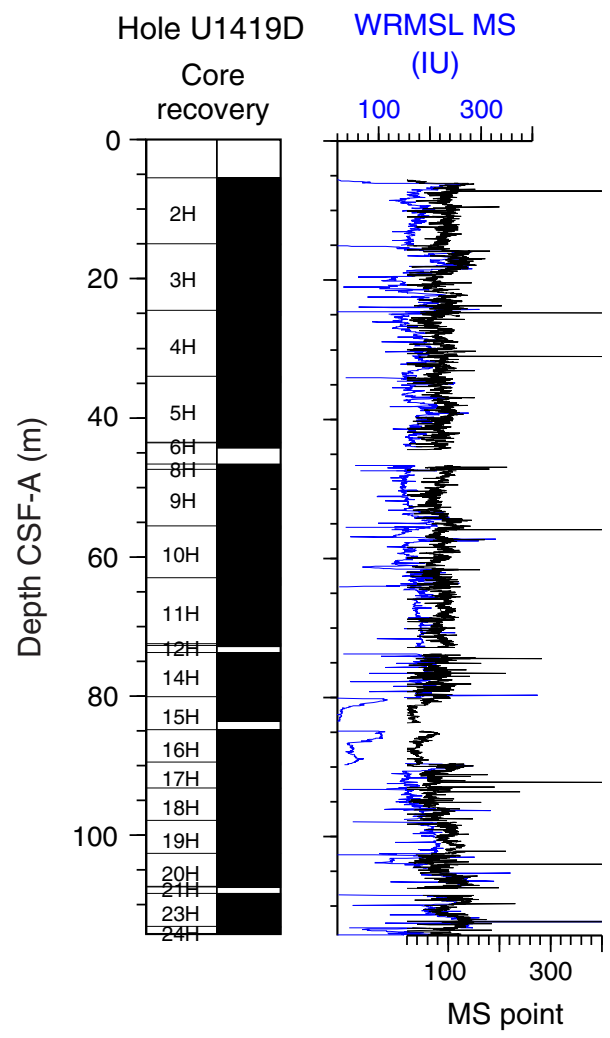

(IU)
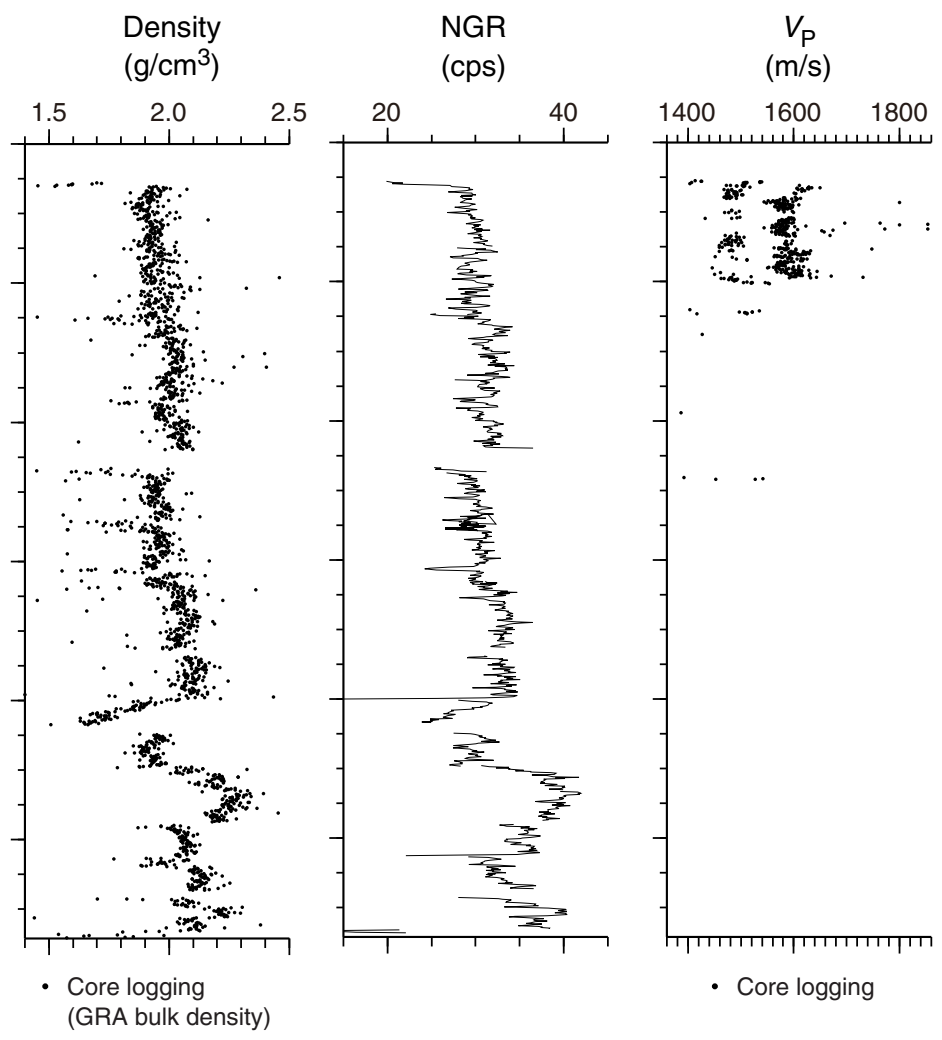
Figure F26. Physical properties measurements, Hole U1419E. WRMSL = Whole-Round Multisensor Logger, MS $=$ magnetic susceptibility. GRA = gamma ray attenuation. NGR = natural gamma radiation .

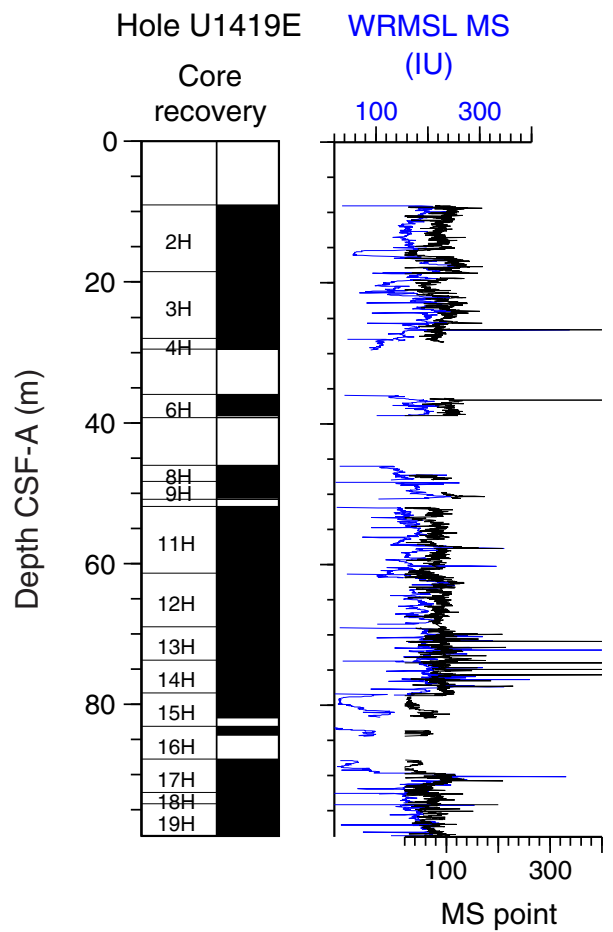

(IU)
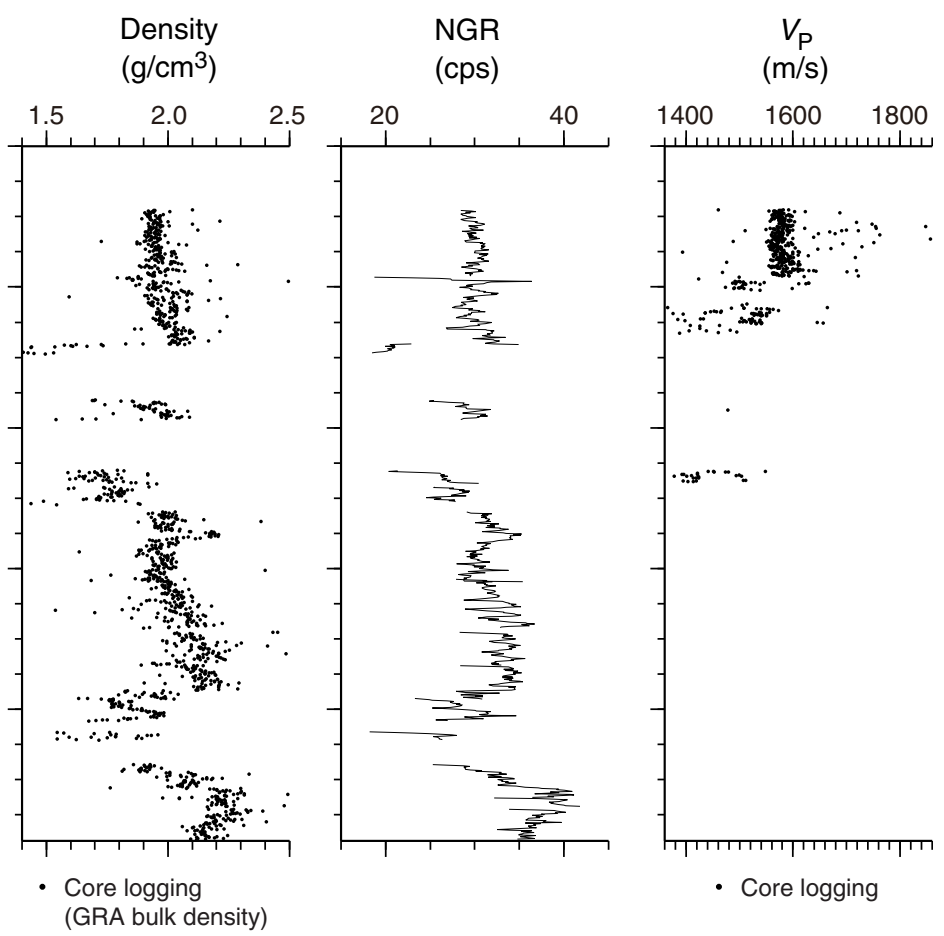
Figure F27. Point-source magnetic susceptibility (MS) data from Holes U1419A-U1419E compared to WholeRound Multisensor Logger (WRMSL) loop MS data from equivalent depths in those cores.

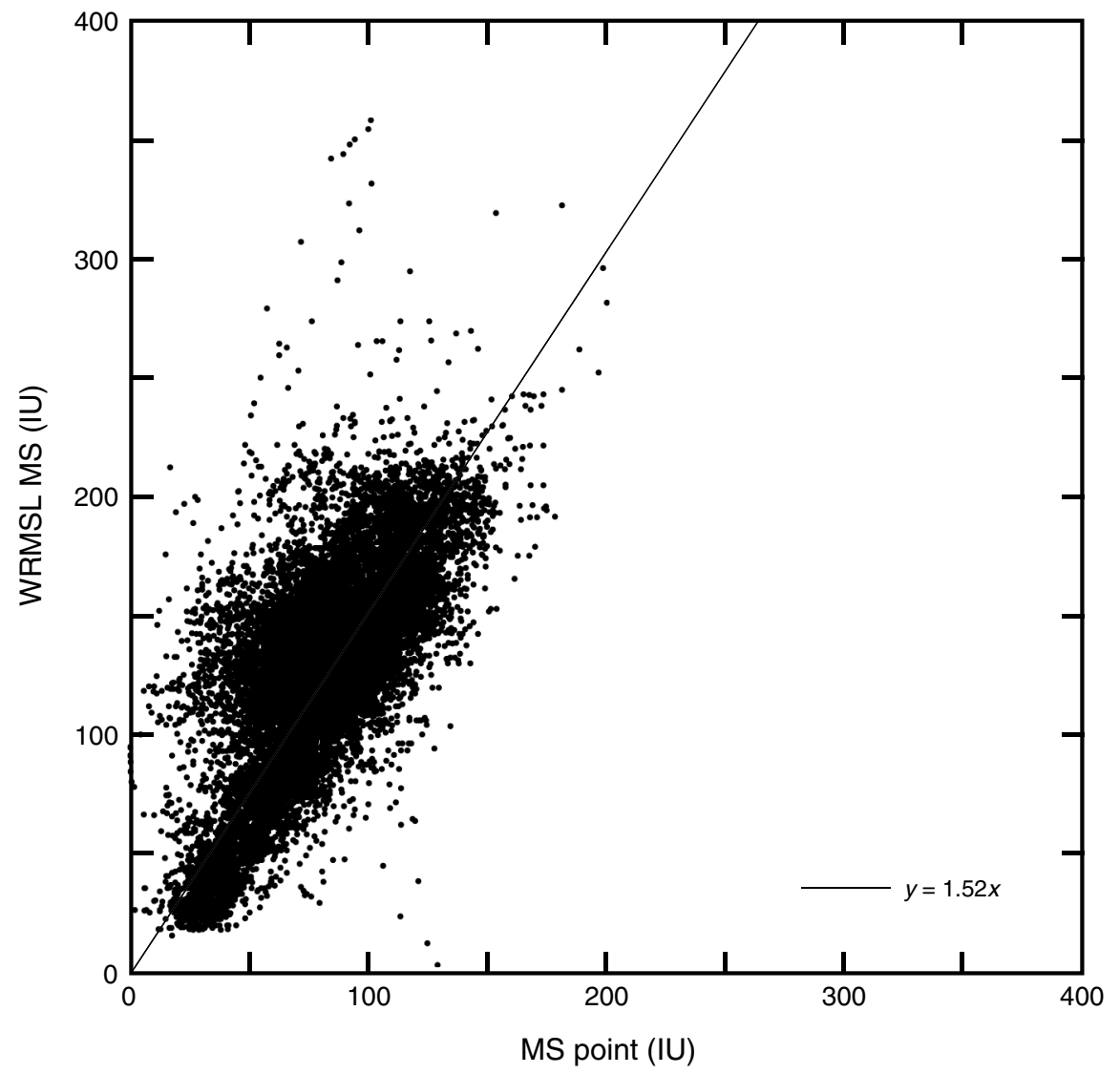


Figure F28. Whole-Round Multisensor Logger (WRMSL) gamma ray attenuation (GRA) bulk density compared to WRMSL magnetic susceptibility (MS) data, Site U1419. Both data sets are shown after Gaussian smoothing with a $10 \mathrm{~cm}$ window $( \pm 3 \sigma)$ and interpolation to constant resolution at $2.5 \mathrm{~cm}$. WRMSL MS ( $\kappa$; black) is also shown corrected for variability in recovered sediment volume by normalizing to WRMSL GRA bulk density, generating mass MS ( $\chi$; blue). Data in the upper $90 \mathrm{~m}$ CCSF-B reflect the stratigraphic splice (see "Stratigraphic correlation"); deeper data from cores in Holes U1419A, U1419C, and U1419D are combined. In this lower interval, when depth horizons were recovered in multiple holes we use an average of all available interpolated data.

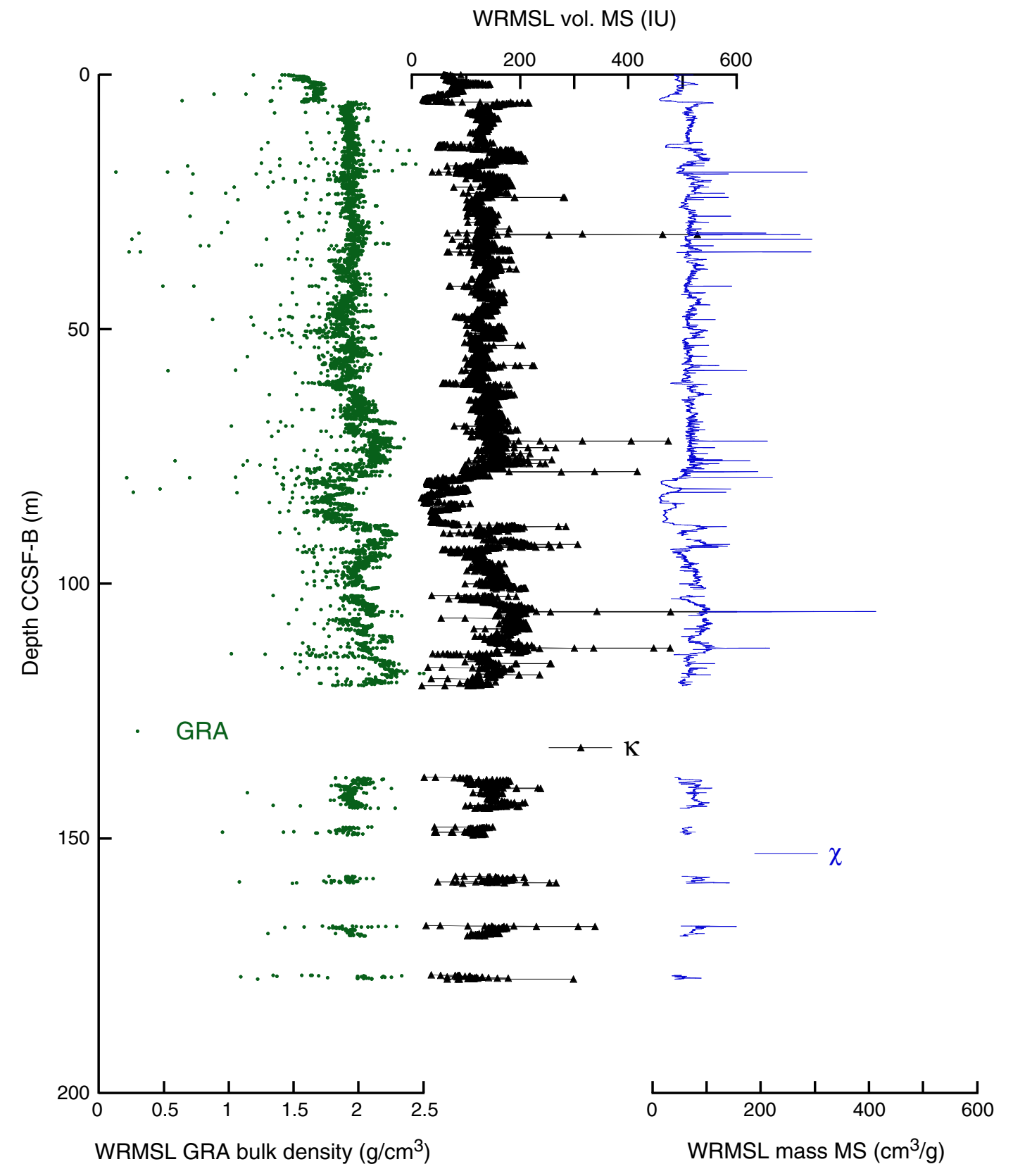


Figure F29. $P$-wave velocity measured by the Whole-Round Multisensor Logger (WRMSL) at $2.5 \mathrm{~cm}$ resolution, Holes U1417C-U1417E.

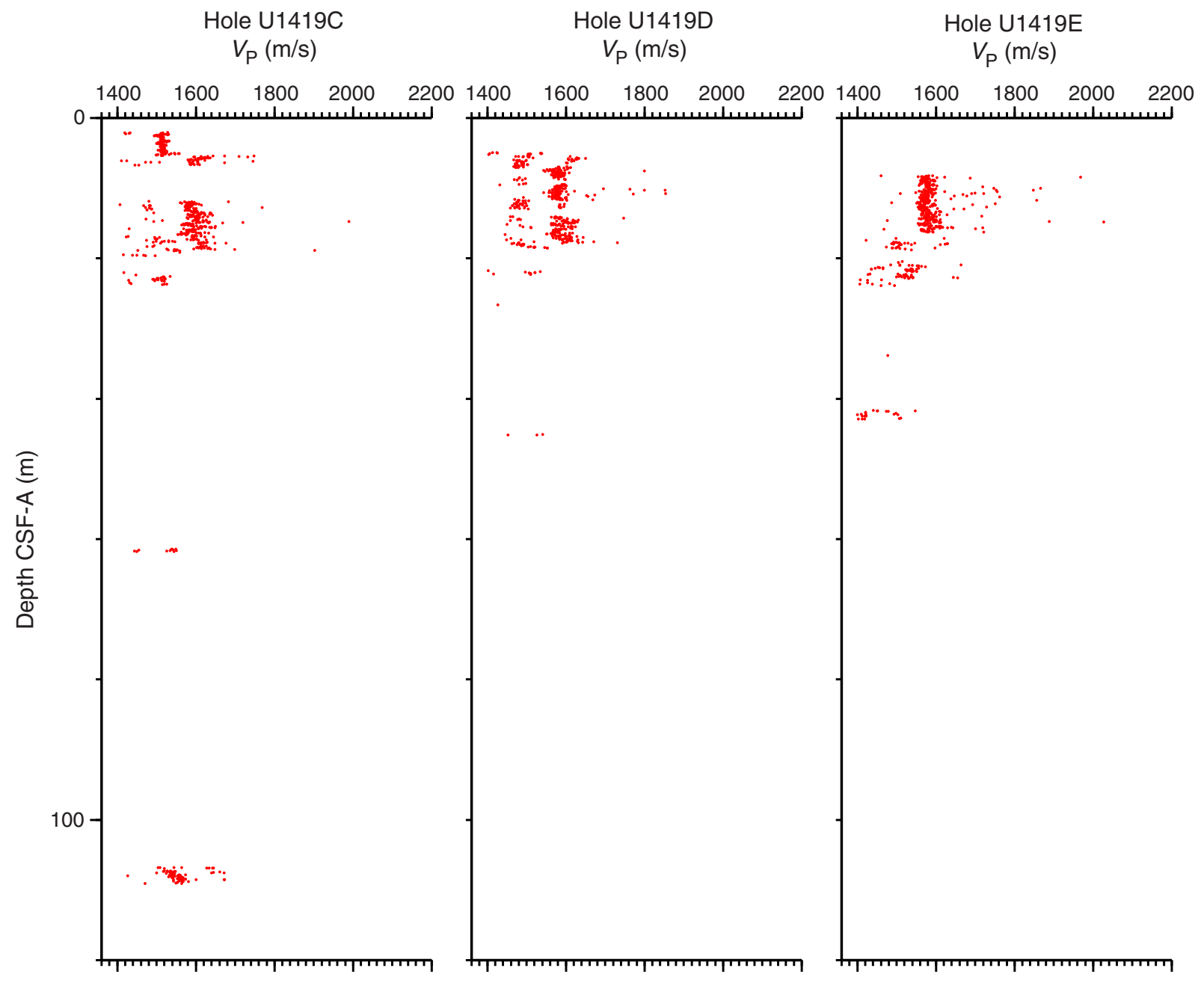


Figure F30. $P$-wave velocity measured by the $P$-wave caliper (PWC) and the $P$-wave logger (PWL), Hole U1419A.

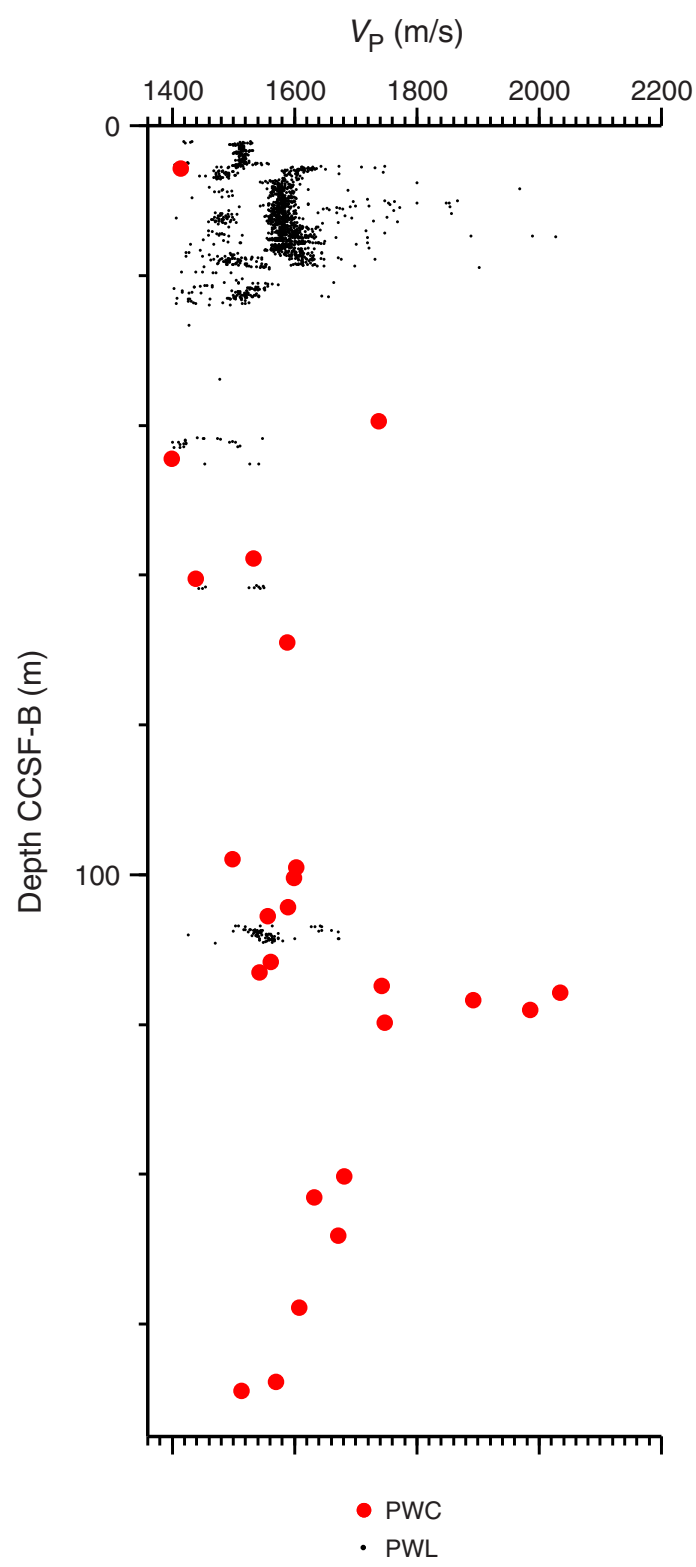


Figure F31. Whole-Round Multisensor Logger (WRMSL) gamma ray attenuation (GRA) bulk density compared to natural gamma radiation (NGR) data, Site U1419. Both data sets are shown after Gaussian smoothing with a $50 \mathrm{~cm}$ window $( \pm 3 \sigma)$ and interpolation to constant resolution at $10 \mathrm{~cm}$. NGR is also shown corrected for variability in recovered sediment volume by normalizing to WRMSL GRA bulk density. From 0 to 90 m CCSF-B, data follow the stratigraphic splice (see "Stratigraphic correlation"); deeper data from XCB and RCB cores in Holes U1419A, U1419C, and U1419D are combined. In this lower interval, when depth horizons were recovered in multiple holes we use an average of all available interpolated data.

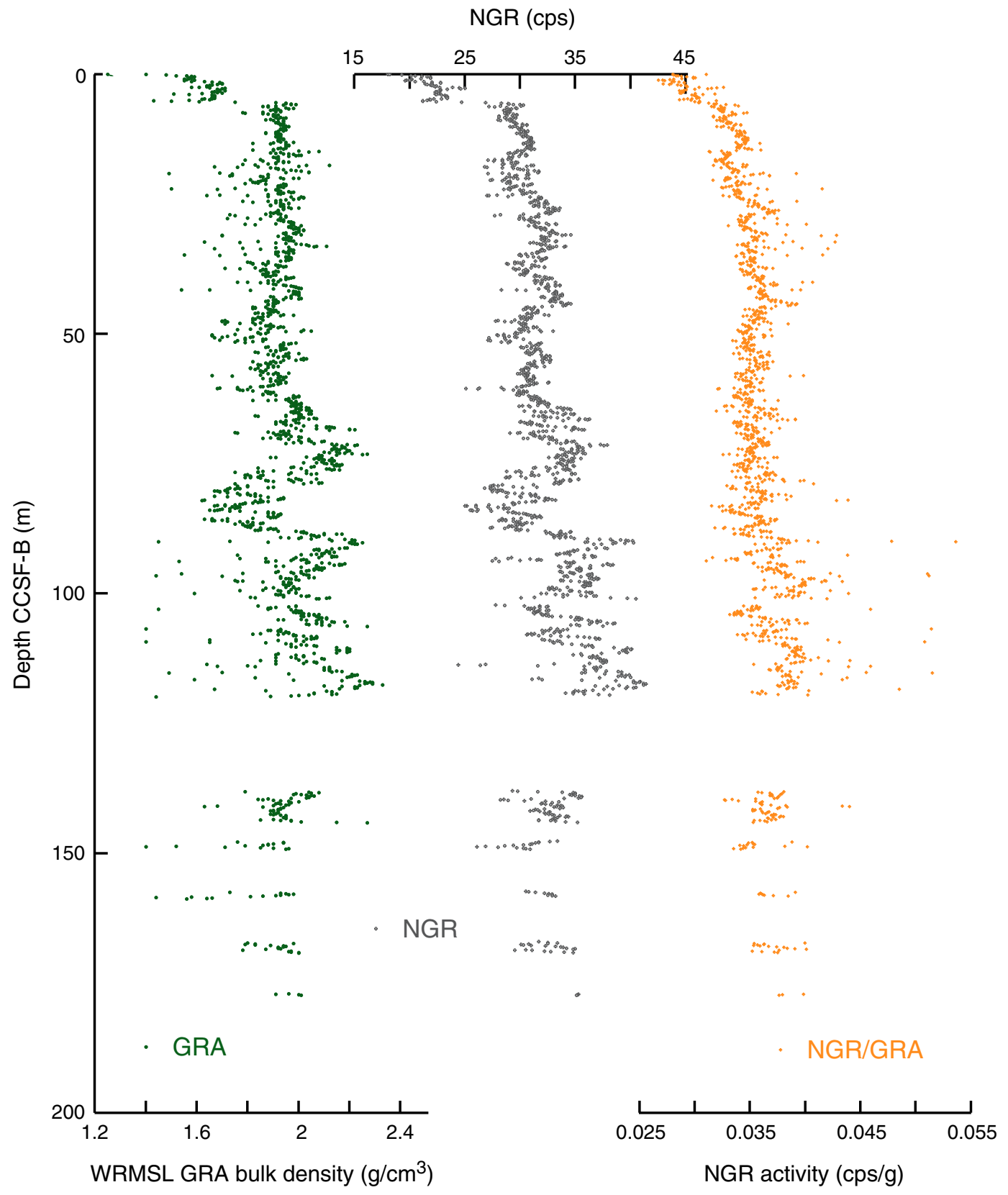


Figure F32. GRA bulk density data measured on the Whole-Round Multisensor Logger (dots) vs. discrete wet bulk density data (circles), Hole U1419.

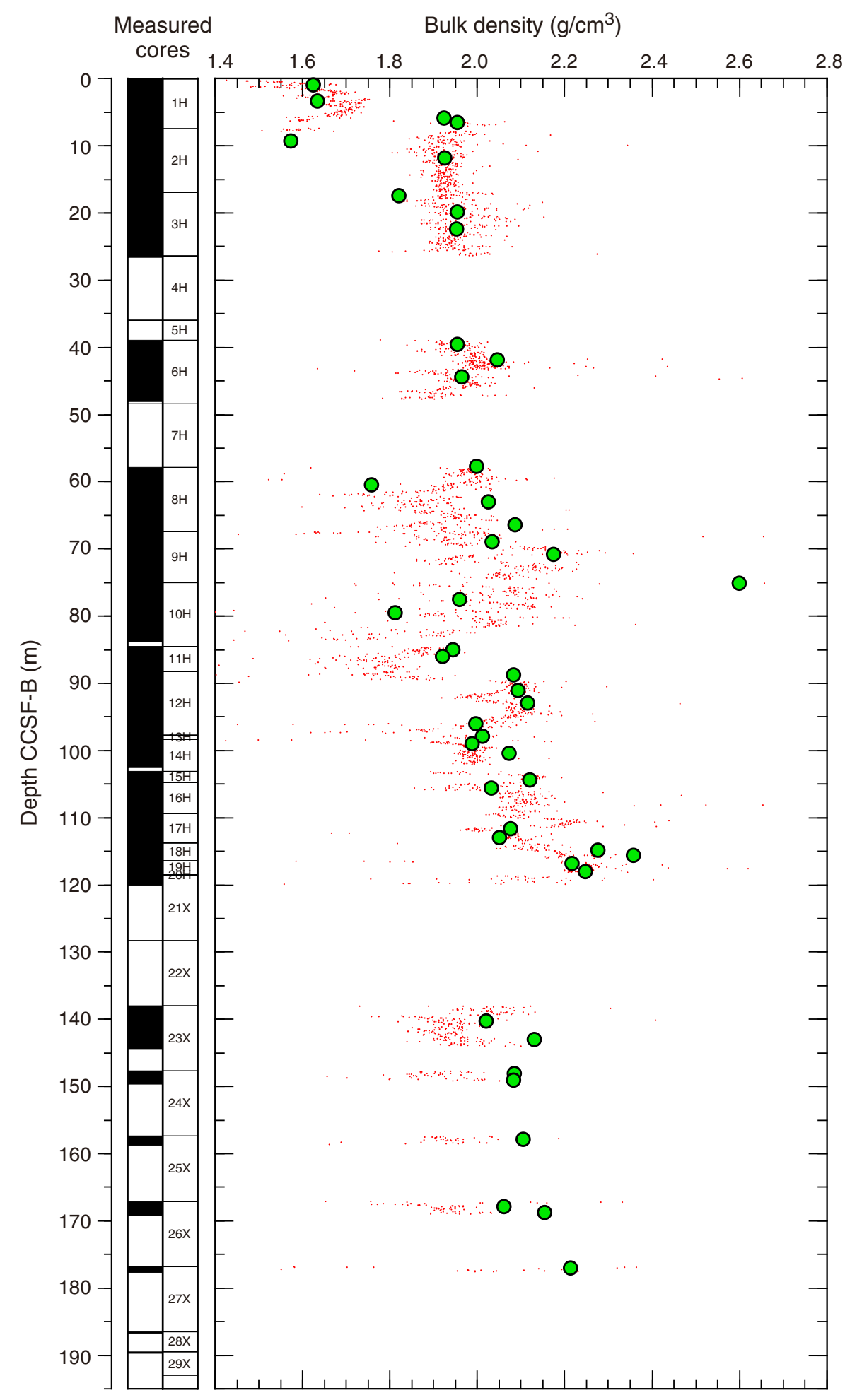




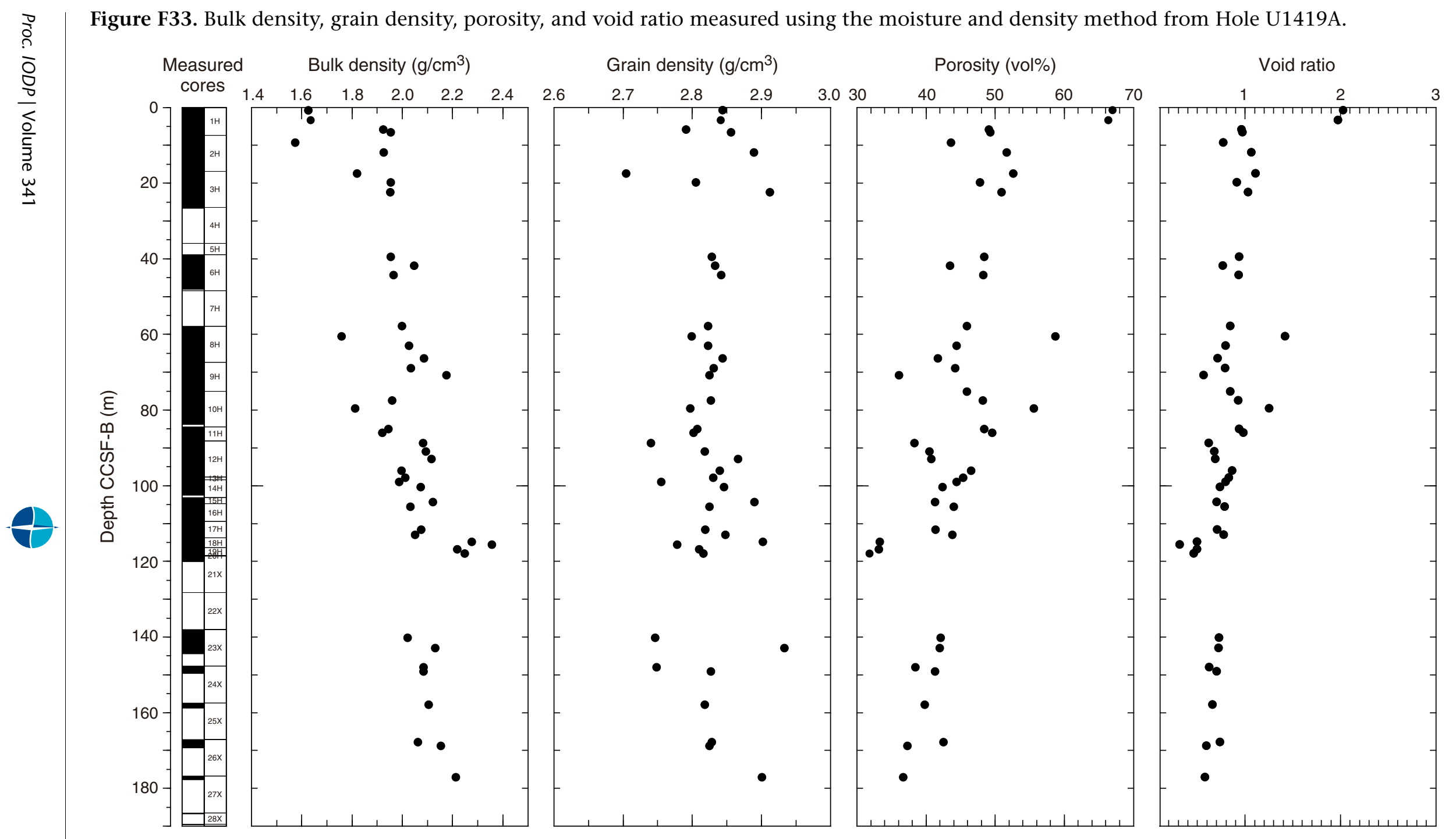


Figure F34. Shear strength values measured by the automatic vane shear system from Hole U1419A.

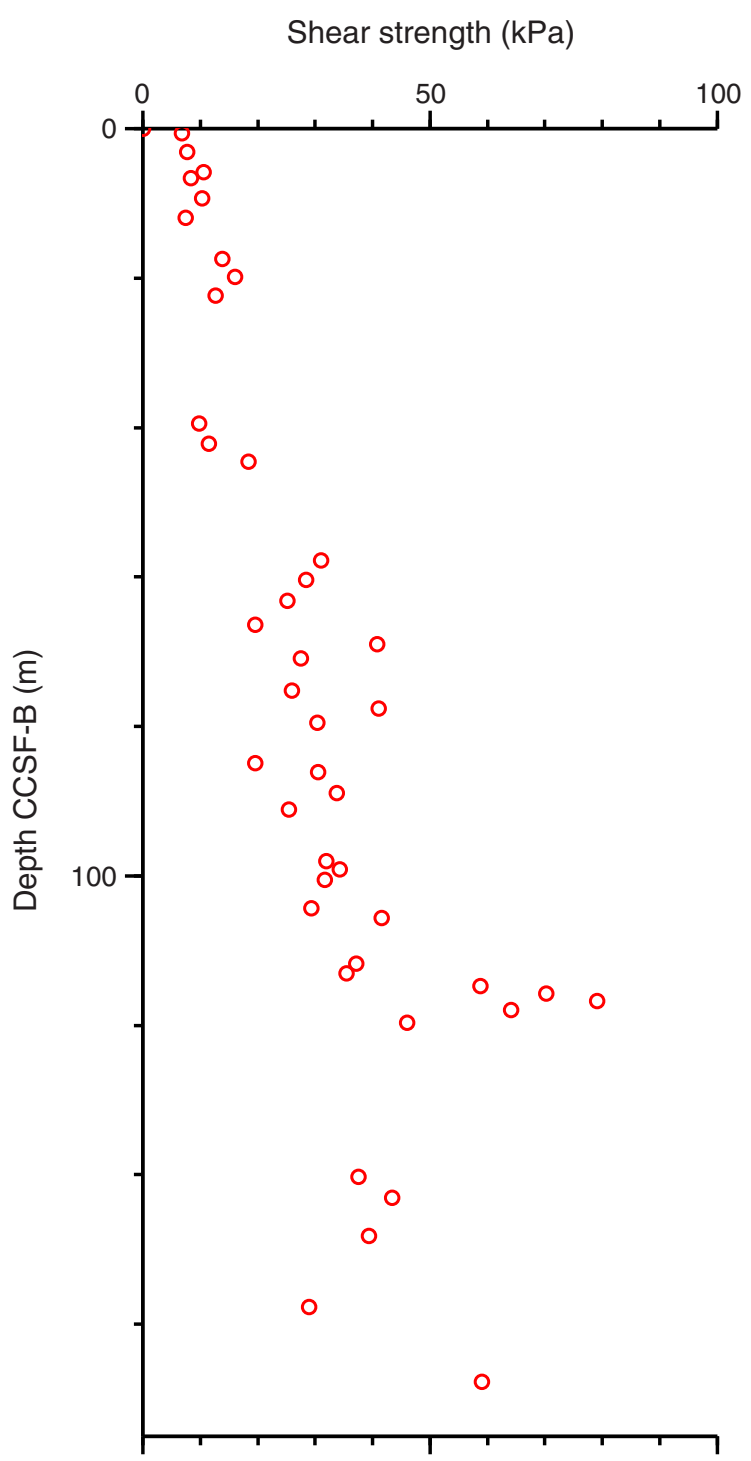


Figure F35. NRM intensity (plotted on a log scale) measured before and after 10 and $20 \mathrm{mT}$ peak AF demagnetization, Holes U1419A-U1419E.

Hole U1419A

Intensity $(\mathrm{A} / \mathrm{m})$

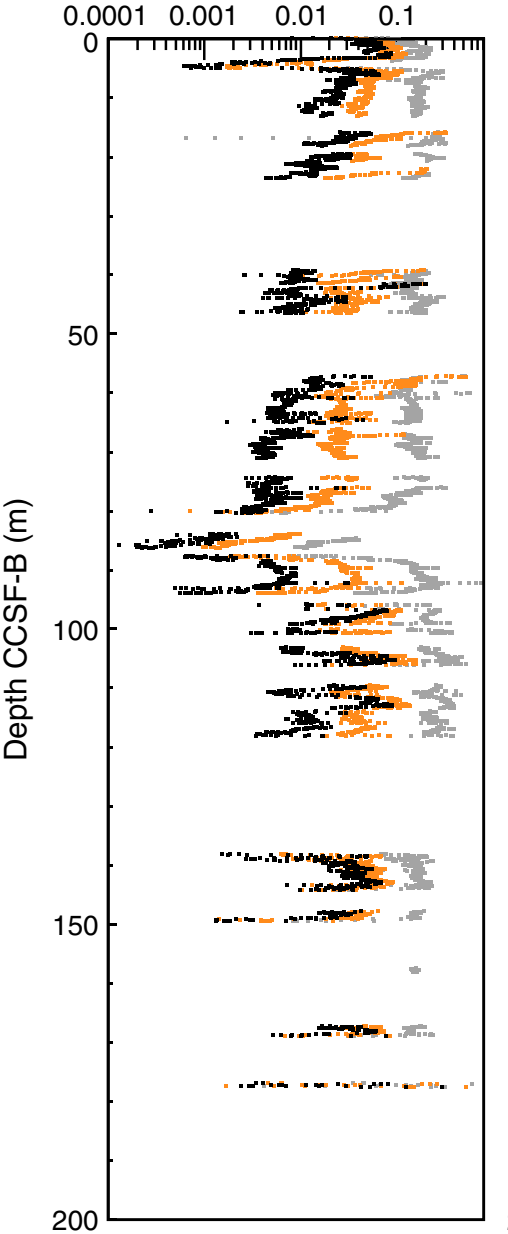

200
Hole U1419B

Intensity $(\mathrm{A} / \mathrm{m})$

$0.0001 \quad 0.001 \quad 0.01 \quad 0.1$

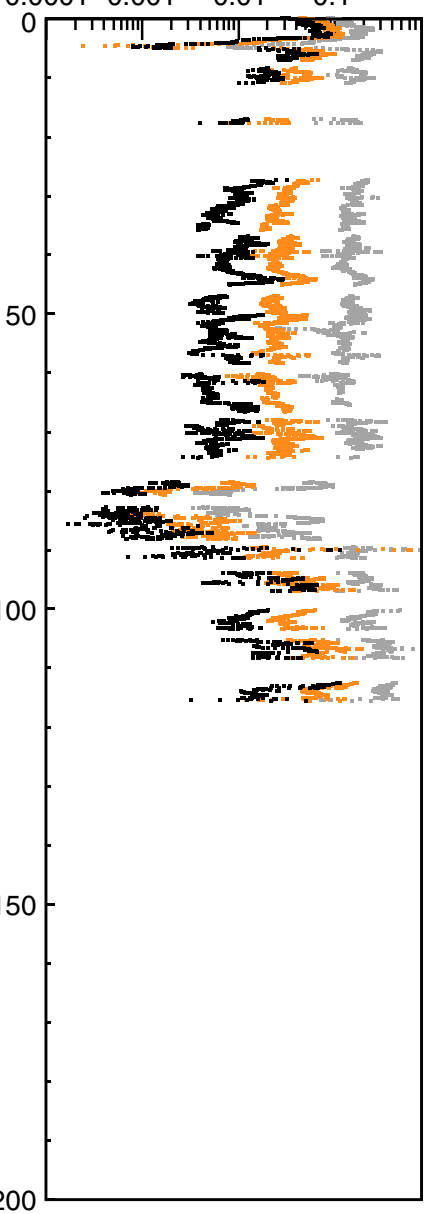

Hole U1419C

Intensity $(\mathrm{A} / \mathrm{m})$

$\begin{array}{llll}0.0001 & 0.001 & 0.01 & 0.1\end{array}$

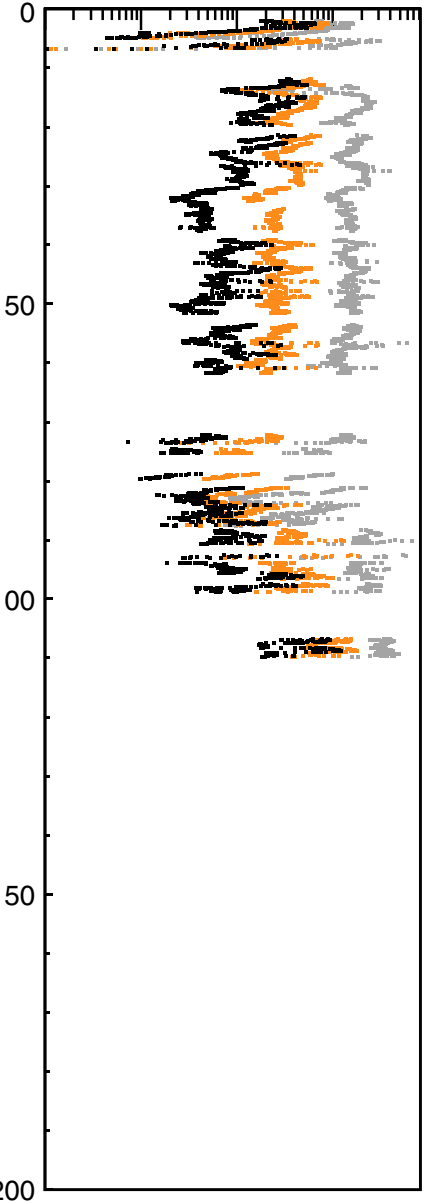

- Intensity $0 \mathrm{mT}$

- Intensity $10 \mathrm{~m}^{-1}$

- Intensity $20 \mathrm{mT}$
Hole U1419D

Intensity $(\mathrm{A} / \mathrm{m})$

$\begin{array}{llll}0.0001 & 0.001 & 0.01 & 0.1\end{array}$

0.00110001

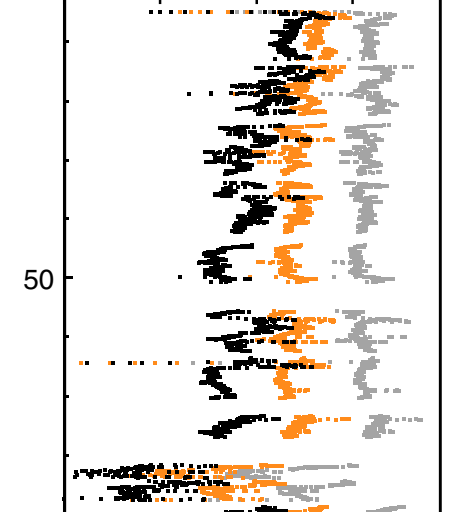

100

$-3+5$

$7 . . .$.

100

$-7$

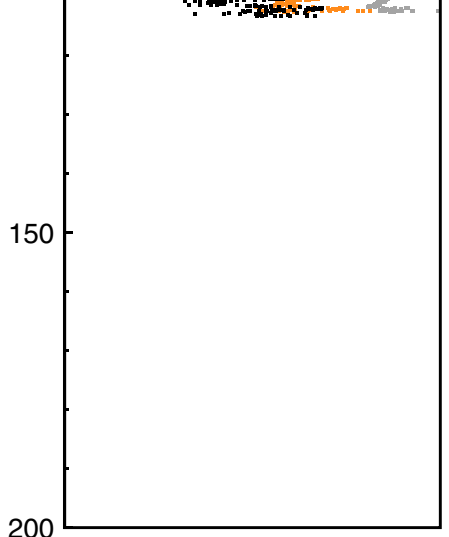

200
U1419E

Intensity $(\mathrm{A} / \mathrm{m})$

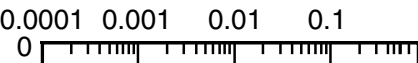

0 -

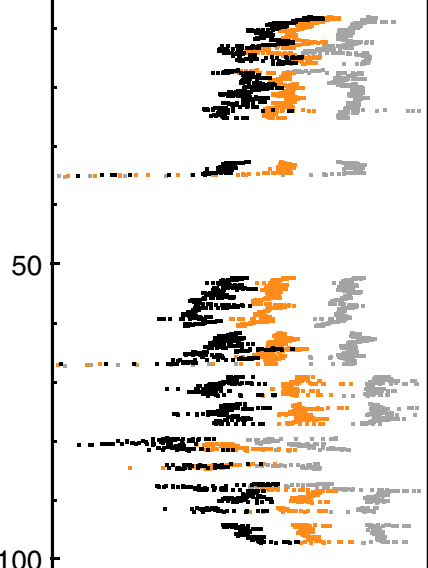

$x$ 
Figure F36. Inclination before and after 10 and $20 \mathrm{mT}$ peak AF demagnetization, Holes U1419A-U1419E.

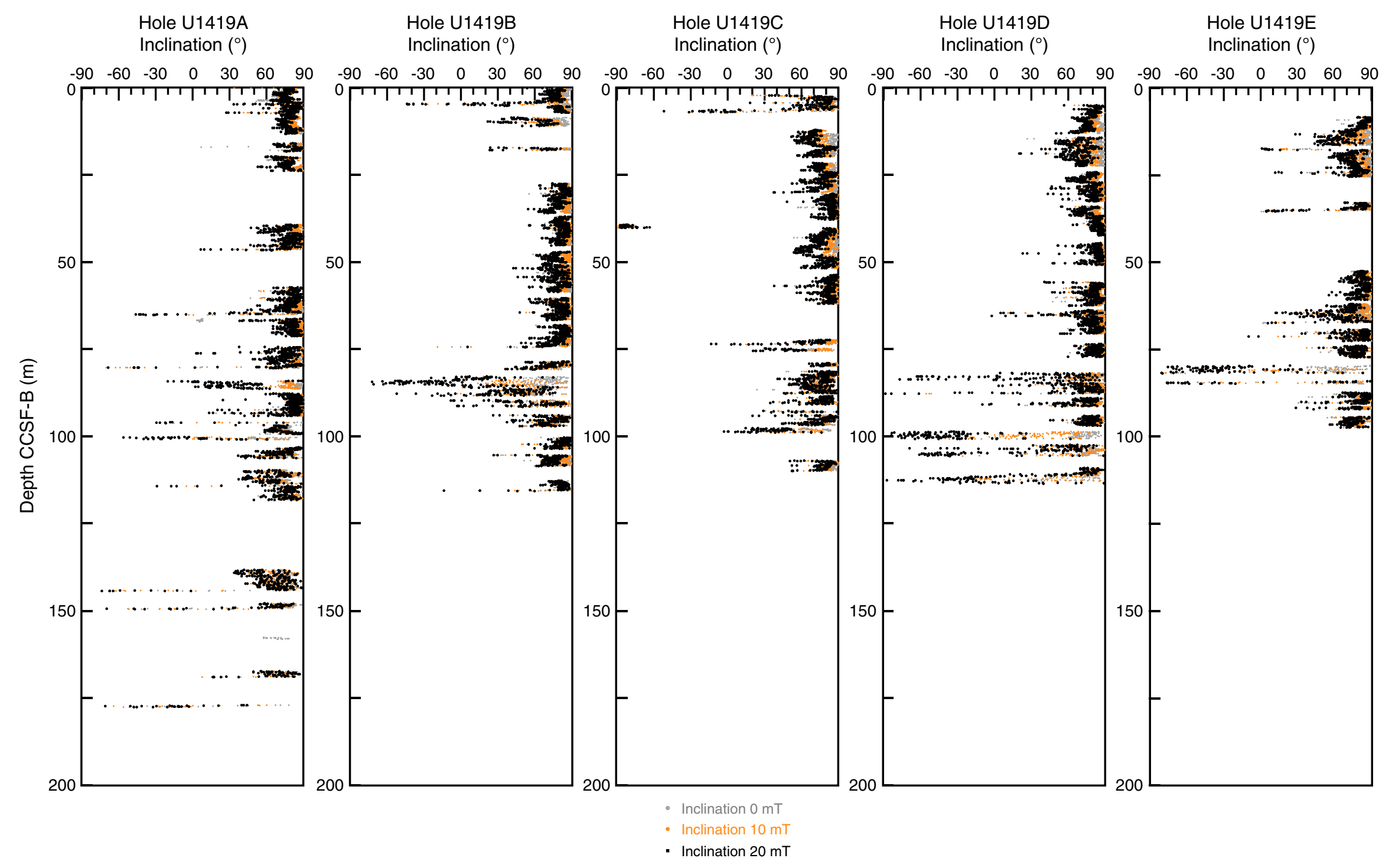


Figure F37. Seismic Profile GOA3101 acquired in 2004 aboard the R/V Maurice Ewing. Seismic Units A-K interpreted for Expedition 341. Vertical resolution at the seafloor $=\sim 5 \mathrm{~m}$.

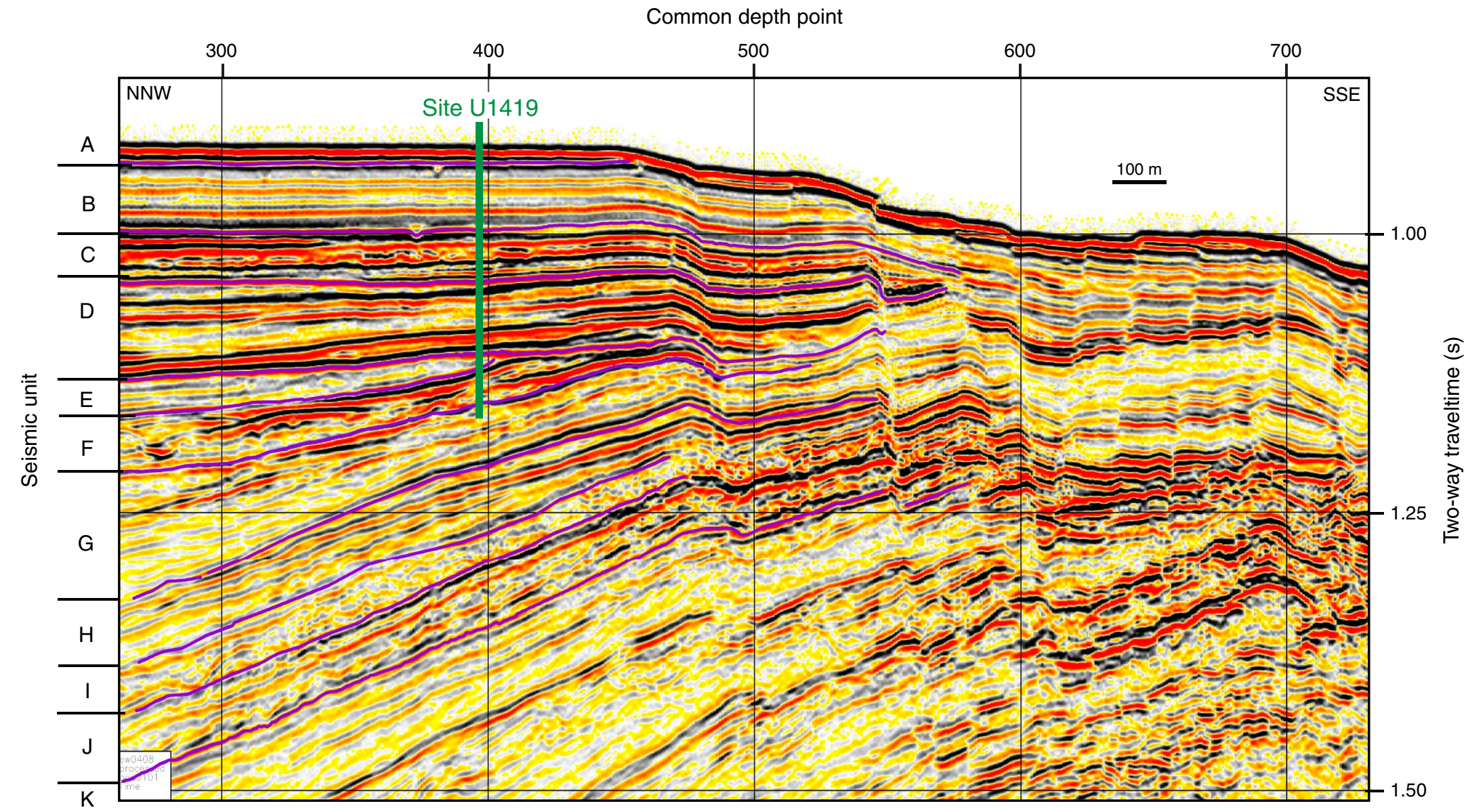


Figure F38. Seismic Profile GOA3102 acquired in 2004 aboard the R/V Maurice Ewing. Seismic Units A-K interpreted for Expedition 341. Vertical resolution at the seafloor $=\sim 5 \mathrm{~m}$.

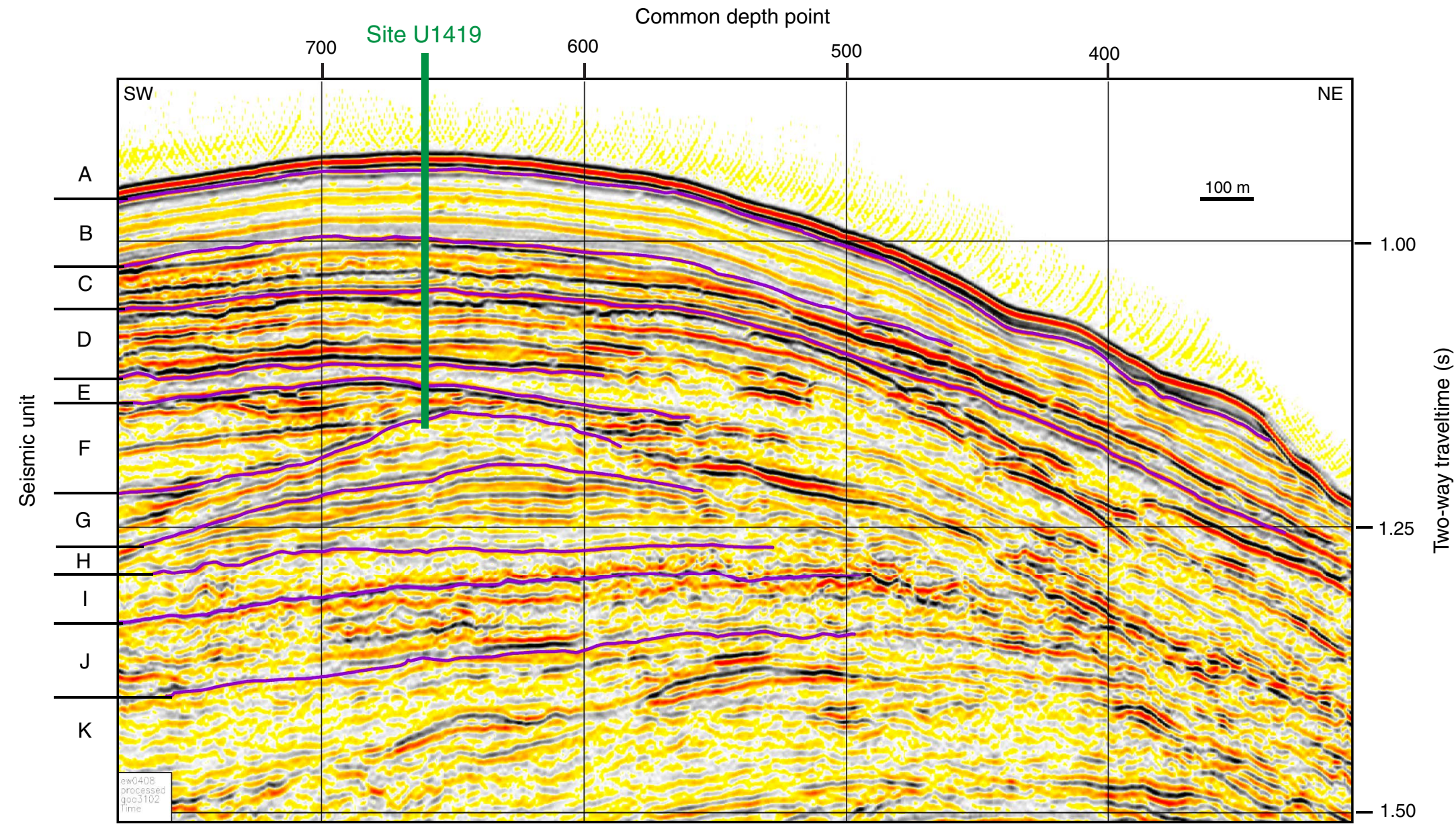


Figure F39. Lithostratigraphic observations, physical properties measurements, and integration with seismic data, Site U1419. Magnetic susceptibility (MS) is volume corrected. $\mathrm{PWL}=P$-wave logger, $\mathrm{PWC}=P$-wave caliper, GRA $=$ gamma ray attenuation, $\mathrm{MAD}=$ discrete density measurement.

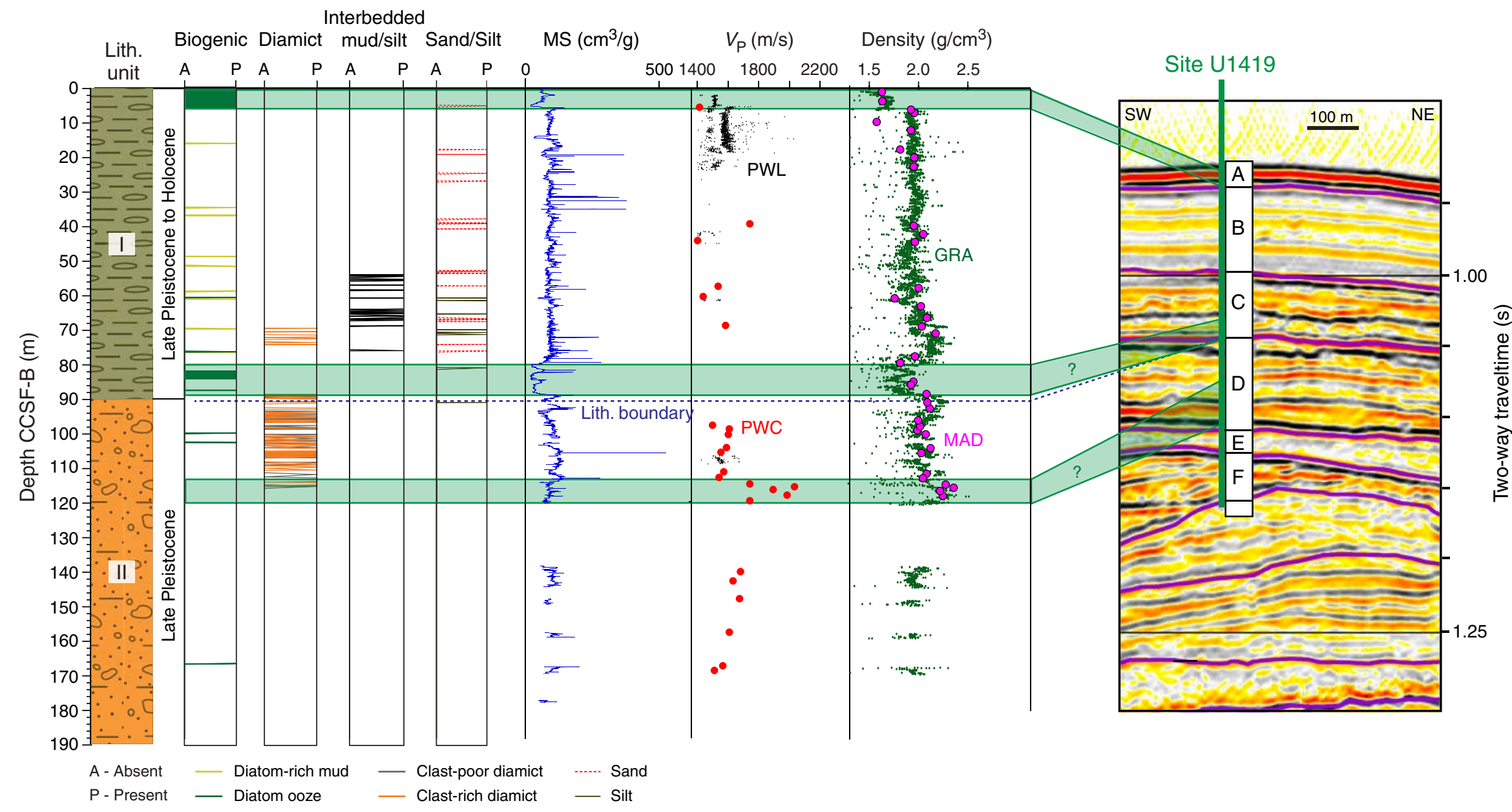


Table T1. Coring summary, Site U1419. (Continued on next two pages.)

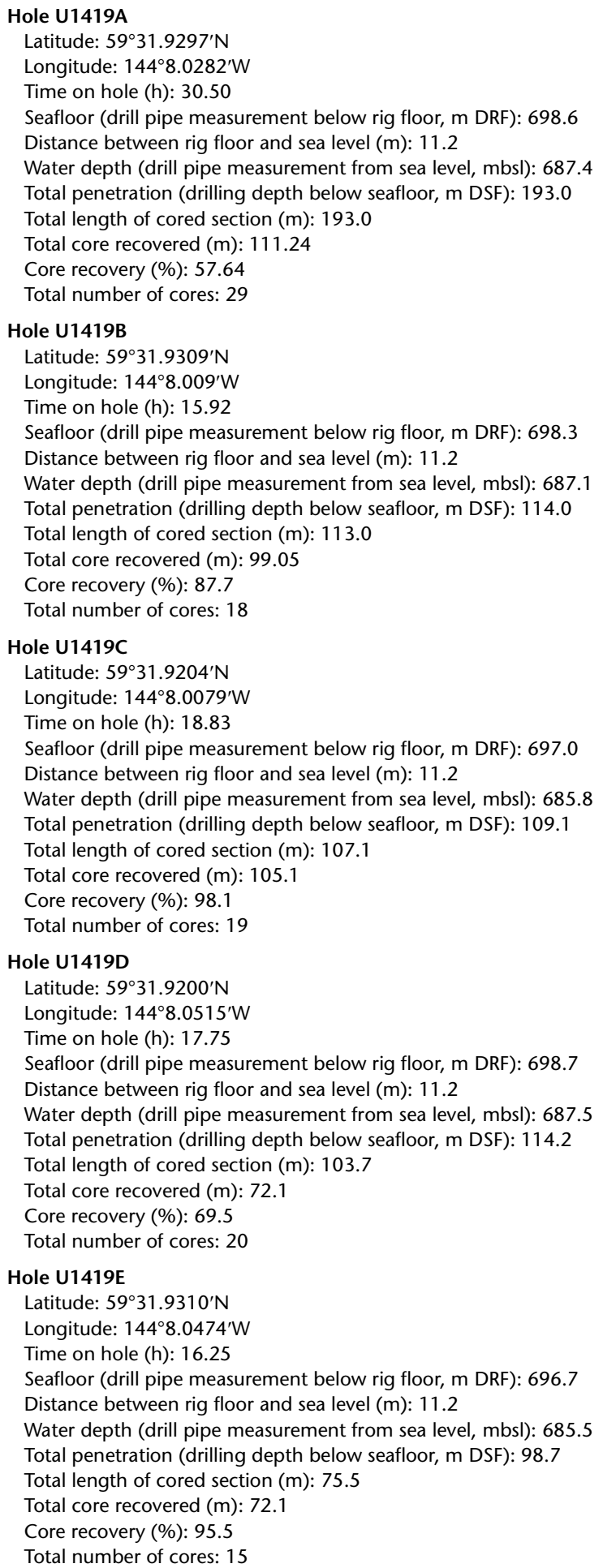

Hole U1419B

Latitude: $59^{\circ} 31.9309^{\prime} \mathrm{N}$

Longitude: $144^{\circ} 8.009^{\prime} \mathrm{W}$

Time on hole $(\mathrm{h}): 15.92$

Seafloor (drill pipe measurement below rig floor, m DRF): 698.3

Distance between rig floor and sea level $(\mathrm{m}): 11.2$

Water depth (drill pipe measurement from sea level, mbsl): 687.1

Total penetration (drilling depth below seafloor, m DSF): 114.0

Total length of cored section $(\mathrm{m}): 113.0$

Total core recovered $(\mathrm{m}): 99.05$

Core recovery (\%): 87.7

Total number of cores: 18

\section{Hole U1419C}

Latitude: $59^{\circ} 31.9204^{\prime} \mathrm{N}$

Longitude: $144^{\circ} 8.0079^{\prime} \mathrm{W}$

Time on hole $(\mathrm{h}): 18.83$

Seafloor (drill pipe measurement below rig floor, m DRF): 697.0

Distance between rig floor and sea level $(\mathrm{m}): 11.2$

Water depth (drill pipe measurement from sea level, mbsl): 685.8

Total penetration (drilling depth below seafloor, m DSF): 109.1

Total length of cored section $(\mathrm{m}): 107.1$

Total core recovered $(\mathrm{m}): 105.1$

Core recovery (\%): 98.1

Total number of cores: 19

\section{Hole U1419D}

Latitude: $59^{\circ} 31.9200^{\prime} \mathrm{N}$

Longitude: $144^{\circ} 8.0515^{\prime} \mathrm{W}$

Time on hole $(\mathrm{h}): 17.75$

Seafloor (drill pipe measurement below rig floor, m DRF): 698.7

Distance between rig floor and sea level $(\mathrm{m}): 11.2$

Water depth (drill pipe measurement from sea level, mbsl): 687.5

Total penetration (drilling depth below seafloor, m DSF): 114.2

Total length of cored section $(\mathrm{m}): 103.7$

Total core recovered $(\mathrm{m}): 72.1$

Core recovery (\%): 69.5

Total number of cores: 20

\section{Hole U1419E}

Latitude: $59^{\circ} 31.9310^{\prime} \mathrm{N}$

Longitude: $144^{\circ} 8.0474^{\prime} \mathrm{W}$

Time on hole (h): 16.25

Seafloor (drill pipe measurement below rig floor, m DRF): 696.7

Distance between rig floor and sea level $(\mathrm{m}): 11.2$

Water depth (drill pipe measurement from sea level, mbsl): 685.5

Total penetration (drilling depth below seafloor, m DSF): 98.7

Total length of cored section $(\mathrm{m}): 75.5$

Total core recovered (m): 72.1

Core recovery (\%): 95.5

Total number of cores: 15

\begin{tabular}{|c|c|c|c|c|c|c|c|c|c|c|c|}
\hline \multirow[b]{2}{*}{ Core } & \multirow[b]{2}{*}{$\begin{array}{l}\text { Date } \\
\text { (2013) }\end{array}$} & \multirow[b]{2}{*}{$\begin{array}{l}\text { UTC time } \\
\text { (h) }\end{array}$} & \multicolumn{2}{|c|}{ Depth DSF (m) } & \multirow[b]{2}{*}{$\begin{array}{l}\text { Interval } \\
\text { advanced } \\
\text { (m) }\end{array}$} & \multicolumn{2}{|c|}{ Depth CSF (m) } & \multirow{2}{*}{$\begin{array}{l}\text { Length } \\
\text { of core } \\
\text { recovered } \\
\text { (m) }\end{array}$} & \multirow[b]{2}{*}{$\begin{array}{l}\text { Recovery } \\
(\%)\end{array}$} & \multirow[b]{2}{*}{$\begin{array}{l}\text { Sections } \\
(N)\end{array}$} & \multirow[b]{2}{*}{$\begin{array}{c}\text { APC } \\
\text { system }\end{array}$} \\
\hline & & & $\begin{array}{c}\text { Top } \\
\text { of cored } \\
\text { interval }\end{array}$ & $\begin{array}{l}\text { Bottom } \\
\text { of cored } \\
\text { interval }\end{array}$ & & $\begin{array}{c}\text { Top } \\
\text { of cored } \\
\text { interval }\end{array}$ & $\begin{array}{l}\text { Bottom } \\
\text { of cored } \\
\text { interval }\end{array}$ & & & & \\
\hline \multicolumn{12}{|c|}{ 341-U1419A- } \\
\hline $1 \mathrm{H}$ & 10 Jul & 1015 & 0 & 7.4 & 7.4 & 0 & 7.43 & 7.43 & 100 & 6 & Full \\
\hline $2 \mathrm{H}$ & $10 \mathrm{Jul}$ & 1100 & 7.4 & 16.9 & 9.5 & 7.4 & 17.20 & 9.80 & 103 & 8 & Full \\
\hline
\end{tabular}


Table T1 (continued). (Continued on next page.)

\begin{tabular}{|c|c|c|c|c|c|c|c|c|c|c|c|}
\hline \multirow[b]{2}{*}{ Core } & \multirow[b]{2}{*}{$\begin{array}{l}\text { Date } \\
(2013)\end{array}$} & \multirow[b]{2}{*}{$\begin{array}{l}\text { UTC time } \\
\text { (h) }\end{array}$} & \multicolumn{2}{|c|}{ Depth DSF (m) } & \multirow[b]{2}{*}{$\begin{array}{l}\text { Interval } \\
\text { advanced } \\
\text { (m) }\end{array}$} & \multicolumn{2}{|c|}{ Depth CSF (m) } & \multirow{2}{*}{$\begin{array}{l}\text { Length } \\
\text { of core } \\
\text { recovered } \\
(\mathrm{m})\end{array}$} & \multirow[b]{2}{*}{$\begin{array}{l}\text { Recovery } \\
(\%)\end{array}$} & \multirow[b]{2}{*}{$\begin{array}{l}\text { Sections } \\
(N)\end{array}$} & \\
\hline & & & $\begin{array}{c}\text { Top } \\
\text { of cored } \\
\text { interval }\end{array}$ & $\begin{array}{l}\text { Bottom } \\
\text { of cored } \\
\text { interval }\end{array}$ & & $\begin{array}{c}\text { Top } \\
\text { of cored } \\
\text { interval }\end{array}$ & $\begin{array}{l}\text { Bottom } \\
\text { of cored } \\
\text { interval }\end{array}$ & & & & $\begin{array}{c}\text { APC } \\
\text { system }\end{array}$ \\
\hline $3 \mathrm{H}$ & $10 \mathrm{Jul}$ & 1125 & 16.9 & 26.4 & 9.5 & 16.9 & 26.65 & 9.75 & 103 & 8 & Full \\
\hline $4 \mathrm{H}$ & $10 \mathrm{Jul}$ & 1150 & 26.4 & 35.9 & 9.5 & 26.4 & 26.40 & 0 & 0 & 0 & Full \\
\hline $5 \mathrm{H}$ & $10 \mathrm{Jul}$ & 1215 & 35.9 & 38.9 & 3.0 & 35.9 & 35.95 & 0.02 & 1 & 1 & Full \\
\hline $6 \mathrm{H}$ & $10 \mathrm{Jul}$ & 1250 & 38.9 & 48.4 & 9.5 & 38.9 & 48.09 & 9.19 & 97 & 7 & Full \\
\hline $7 \mathrm{H}$ & $10 \mathrm{Jul}$ & 1330 & 48.4 & 57.9 & 9.5 & 48.4 & 48.40 & 0 & 0 & 0 & Full \\
\hline $8 \mathrm{H}$ & $10 \mathrm{Jul}$ & 1355 & 57.9 & 67.4 & 9.5 & 57.9 & 68.21 & 9.94 & 105 & 8 & Full \\
\hline $9 \mathrm{H}$ & $10 \mathrm{Jul}$ & 1430 & 67.4 & 75.0 & 7.6 & 67.4 & 75.07 & 7.57 & 100 & 6 & Full \\
\hline $10 \mathrm{H}$ & 10 Jul & 1530 & 75.0 & 84.5 & 9.5 & 75.0 & 83.79 & 8.79 & 93 & 7 & Full \\
\hline $11 \mathrm{H}$ & $10 \mathrm{Jul}$ & 1719 & 84.5 & 88.2 & 3.7 & 84.5 & 88.29 & 3.79 & 102 & 4 & Full \\
\hline $12 \mathrm{H}$ & $10 \mathrm{Jul}$ & 1840 & 88.2 & 97.7 & 9.5 & 88.2 & 97.76 & 9.56 & 101 & 8 & Full \\
\hline $13 \mathrm{H}$ & $10 \mathrm{Jul}$ & 2020 & 97.7 & 98.4 & 0.7 & 97.7 & 98.41 & 0.71 & 101 & 2 & Half \\
\hline $14 \mathrm{H}$ & $10 \mathrm{Jul}$ & 2115 & 98.4 & 103.1 & 4.7 & 98.4 & 102.49 & 4.09 & 87 & 4 & Half \\
\hline $15 \mathrm{H}$ & $10 \mathrm{Jul}$ & 2145 & 103.1 & 104.7 & 1.6 & 103.1 & 104.73 & 1.63 & 102 & 2 & Half \\
\hline $16 \mathrm{H}$ & $10 \mathrm{Jul}$ & 2215 & 104.7 & 109.4 & 4.7 & 104.7 & 109.59 & 4.89 & 104 & 5 & Half \\
\hline $17 \mathrm{H}$ & $10 \mathrm{Jul}$ & 2250 & 109.4 & 113.8 & 4.4 & 109.4 & 113.80 & 4.40 & 100 & 4 & Half \\
\hline $18 \mathrm{H}$ & $10 \mathrm{Jul}$ & 2350 & 113.8 & 116.4 & 2.6 & 113.8 & 116.45 & 2.65 & 102 & 3 & Half \\
\hline $19 \mathrm{H}$ & $11 \mathrm{Jul}$ & 0040 & 116.4 & 118.5 & 2.1 & 116.4 & 118.55 & 2.15 & 102 & 3 & Half \\
\hline $20 \mathrm{H}$ & $11 \mathrm{Jul}$ & 0110 & 118.5 & 118.6 & 0.1 & 118.5 & 118.52 & 0.02 & 20 & 1 & Half \\
\hline $21 X$ & $11 \mathrm{Jul}$ & 0300 & 118.6 & 128.3 & 9.7 & 118.6 & 120.05 & 1.45 & 15 & 2 & \\
\hline $22 x$ & $11 \mathrm{Jul}$ & 0410 & 128.3 & 138.0 & 9.7 & 128.3 & 128.30 & 0 & 0 & 0 & \\
\hline $23 x$ & $11 \mathrm{Jul}$ & 0505 & 138.0 & 147.7 & 9.7 & 138.0 & 144.48 & 6.48 & 67 & 6 & \\
\hline $24 X$ & $11 \mathrm{Jul}$ & 0545 & 147.7 & 157.4 & 9.7 & 147.7 & 149.70 & 2.00 & 21 & 3 & \\
\hline $25 x$ & $11 \mathrm{Jul}$ & 0635 & 157.4 & 167.1 & 9.7 & 157.4 & 158.76 & 1.36 & 14 & 2 & \\
\hline $26 x$ & $11 \mathrm{Jul}$ & 0725 & 167.1 & 176.8 & 9.7 & 167.1 & 169.28 & 2.18 & 22 & 3 & \\
\hline $27 x$ & $11 \mathrm{Jul}$ & 0815 & 176.8 & 186.5 & 9.7 & 176.8 & 177.77 & 0.97 & 10 & 2 & \\
\hline $28 \mathrm{X}$ & $11 \mathrm{Jul}$ & 0910 & 186.5 & 189.5 & 3.0 & 186.5 & 186.74 & 0.24 & 8 & 1 & \\
\hline $29 x$ & $11 \mathrm{Jul}$ & 1005 & 189.5 & 193.0 & 3.5 & 189.5 & 189.68 & 0.18 & 5 & 1 & \\
\hline 341-U14 & & & & & & & & & & & \\
\hline $1 \mathrm{H}$ & $11 \mathrm{Jul}$ & 1335 & 0 & 8.5 & 8.5 & 0 & 8.53 & 8.53 & 100 & 7 & Full \\
\hline $2 \mathrm{H}$ & $11 \mathrm{Jul}$ & 1420 & 8.5 & 18.0 & 9.5 & 8.5 & 11.94 & 3.44 & 36 & 4 & Full \\
\hline $3 \mathrm{H}$ & $11 \mathrm{Jul}$ & 1450 & 18.0 & 27.5 & 9.5 & 18.0 & 19.35 & 1.35 & 14 & 2 & Full \\
\hline $4 \mathrm{H}$ & $11 \mathrm{Jul}$ & 1525 & 27.5 & 37.0 & 9.5 & 27.5 & 37.79 & 9.88 & 104 & 8 & Full \\
\hline $5 \mathrm{H}$ & $11 \mathrm{Jul}$ & 1550 & 37.0 & 46.5 & 9.5 & 37.0 & 47.32 & 9.97 & 105 & 8 & Full \\
\hline $6 \mathrm{H}$ & $11 \mathrm{Jul}$ & 1620 & 46.5 & 50.4 & 3.9 & 46.5 & 50.48 & 3.92 & 101 & 4 & Full \\
\hline $7 \mathrm{H}$ & $11 \mathrm{Jul}$ & 1705 & 50.4 & 59.9 & 9.5 & 50.4 & 60.56 & 9.78 & 103 & 8 & Full \\
\hline $8 \mathrm{H}$ & $11 \mathrm{Jul}$ & 1740 & 59.9 & 69.3 & 9.4 & 59.9 & 69.61 & 9.40 & 100 & 8 & Full \\
\hline $9 \mathrm{H}$ & $11 \mathrm{Jul}$ & 1825 & 69.3 & 78.1 & 8.8 & 69.3 & 78.23 & 8.80 & 100 & 7 & Full \\
\hline $10 \mathrm{H}$ & $11 \mathrm{Jul}$ & 1920 & 78.1 & 81.8 & 3.7 & 78.1 & 81.87 & 3.70 & 100 & 4 & Full \\
\hline $11 \mathrm{H}$ & $11 \mathrm{Jul}$ & 2020 & 81.8 & 86.5 & 4.7 & 81.8 & 86.75 & 4.73 & 101 & 5 & Half \\
\hline $12 \mathrm{H}$ & $11 \mathrm{Jul}$ & 2045 & 86.5 & 91.2 & 4.7 & 86.5 & 89.67 & 3.17 & 67 & 3 & Half \\
\hline $13 \mathrm{H}$ & $11 \mathrm{Jul}$ & 2145 & 91.2 & 95.5 & 4.3 & 91.2 & 95.68 & 4.37 & 102 & 4 & Half \\
\hline $14 \mathrm{H}$ & $11 \mathrm{Jul}$ & 2235 & 95.5 & 100.2 & 4.7 & 95.5 & 100.29 & 4.79 & 102 & 5 & Half \\
\hline $15 \mathrm{H}$ & $11 \mathrm{Jul}$ & 2330 & 100.2 & 104.9 & 4.7 & 100.2 & 105.16 & 4.96 & 106 & 5 & Half \\
\hline $16 \mathrm{H}$ & $12 \mathrm{Jul}$ & 0005 & 104.9 & 109.6 & 4.7 & 104.9 & 109.73 & 4.83 & 103 & 5 & Half \\
\hline $17 \mathrm{H}$ & $12 \mathrm{Jul}$ & 0100 & 109.6 & 109.6 & 0 & 109.6 & 109.60 & 0 & 0 & 0 & Half \\
\hline 181 & $12 \mathrm{Jul}$ & & & & ${ }^{* *}$ Drilled int & erval from & 09.6 to 11 & $0.6 \mathrm{~m} \mathrm{DSF} F^{* *}$ & & & \\
\hline $19 \mathrm{H}$ & $12 \mathrm{Jul}$ & 0145 & 110.6 & 114.0 & 3.4 & 110.6 & 114.03 & 3.43 & 101 & 4 & Half \\
\hline 341-U14 & & & & & & & & & & & \\
\hline 11 & $12 \mathrm{Jul}$ & & & & $* \star \star * \star$ Drilled & interval fro & $\mathrm{m} 0$ to 2.0 & $\mathrm{~m}$ DSF $F^{\star * * * *}$ & & & \\
\hline $2 \mathrm{H}$ & $12 \mathrm{Jul}$ & 0515 & 2.0 & 11.5 & 9.5 & 2.0 & 7.83 & 5.83 & 61 & 5 & Full \\
\hline $3 \mathrm{H}$ & $12 \mathrm{Jul}$ & 0620 & 11.5 & 21.0 & 9.5 & 11.5 & 21.11 & 9.53 & 100 & 8 & Full \\
\hline $4 \mathrm{H}$ & $12 \mathrm{Jul}$ & 0655 & 21.0 & 30.5 & 9.5 & 21.0 & 31.38 & 10.04 & 106 & 8 & Full \\
\hline $5 \mathrm{H}$ & $12 \mathrm{Jul}$ & 0715 & 30.5 & 39.2 & 8.7 & 30.5 & 39.78 & 8.75 & 101 & 7 & Full \\
\hline $6 \mathrm{H}$ & $12 \mathrm{Jul}$ & 0755 & 39.2 & 48.7 & 9.5 & 39.2 & 49.32 & 9.83 & 103 & 8 & Full \\
\hline $7 \mathrm{H}$ & $12 \mathrm{Jul}$ & 0830 & 48.7 & 53.5 & 4.8 & 48.7 & 53.54 & 4.82 & 100 & 5 & Full \\
\hline $8 \mathrm{H}$ & $12 \mathrm{Jul}$ & 0950 & 53.5 & 63.0 & 9.5 & 53.5 & 63.82 & 10.05 & 106 & 8 & Full \\
\hline $9 \mathrm{H}$ & $12 \mathrm{Jul}$ & 1020 & 63.0 & 72.3 & 9.3 & 63.0 & 72.51 & 9.36 & 101 & 8 & Full \\
\hline $10 \mathrm{H}$ & $12 \mathrm{Jul}$ & 1120 & 72.3 & 77.1 & 4.8 & 72.3 & 77.16 & 4.86 & 101 & 5 & Full \\
\hline $11 \mathrm{H}$ & $12 \mathrm{Jul}$ & 1345 & 77.1 & 78.7 & 1.6 & 77.1 & 78.70 & 1.60 & 100 & 2 & Full \\
\hline $12 \mathrm{H}$ & $12 \mathrm{Jul}$ & 1440 & 78.7 & 83.4 & 4.7 & 78.7 & 83.71 & 4.93 & 105 & 5 & Half \\
\hline $13 \mathrm{H}$ & $12 \mathrm{Jul}$ & 1505 & 83.4 & 88.1 & 4.7 & 83.4 & 88.25 & 4.85 & 103 & 5 & Half \\
\hline $14 \mathrm{H}$ & $12 \mathrm{Jul}$ & 1530 & 88.1 & 91.8 & 3.7 & 88.1 & 91.84 & 3.69 & 100 & 4 & Half \\
\hline $15 \mathrm{H}$ & $12 \mathrm{Jul}$ & 1605 & 91.8 & 92.9 & 1.1 & 91.8 & 92.92 & 1.12 & 102 & 2 & Half \\
\hline $16 \mathrm{H}$ & $12 \mathrm{Jul}$ & 1640 & 92.9 & 97.3 & 4.4 & 92.9 & 97.43 & 4.45 & 101 & 4 & Half \\
\hline $17 \mathrm{H}$ & $12 \mathrm{Jul}$ & 1740 & 97.3 & 99.6 & 2.3 & 97.3 & 99.59 & 2.29 & 100 & 3 & Half \\
\hline $18 \mathrm{H}$ & $12 \mathrm{Jul}$ & 1820 & 99.6 & 104.3 & 4.7 & 99.6 & 99.60 & 0 & 0 & 0 & Half \\
\hline
\end{tabular}


Table T1 (continued).

\begin{tabular}{|c|c|c|c|c|c|c|c|c|c|c|c|}
\hline \multirow[b]{2}{*}{ Core } & \multirow[b]{2}{*}{$\begin{array}{l}\text { Date } \\
\text { (2013) }\end{array}$} & \multirow[b]{2}{*}{$\begin{array}{l}\text { UTC time } \\
\text { (h) }\end{array}$} & \multicolumn{2}{|c|}{ Depth DSF (m) } & \multirow[b]{2}{*}{$\begin{array}{l}\text { Interval } \\
\text { advanced } \\
(\mathrm{m})\end{array}$} & \multicolumn{2}{|c|}{ Depth CSF (m) } & \multirow{2}{*}{$\begin{array}{l}\text { Length } \\
\text { of core } \\
\text { recovered } \\
(\mathrm{m})\end{array}$} & \multirow[b]{2}{*}{$\begin{array}{l}\text { Recovery } \\
\text { (\%) }\end{array}$} & \multirow[b]{2}{*}{$\begin{array}{l}\text { Sections } \\
(N)\end{array}$} & \multirow[b]{2}{*}{$\begin{array}{c}\text { APC } \\
\text { system }\end{array}$} \\
\hline & & & $\begin{array}{c}\text { Top } \\
\text { of cored } \\
\text { interval }\end{array}$ & $\begin{array}{l}\text { Bottom } \\
\text { of cored } \\
\text { interval }\end{array}$ & & $\begin{array}{c}\text { Top } \\
\text { of cored } \\
\text { interval }\end{array}$ & $\begin{array}{l}\text { Bottom } \\
\text { of cored } \\
\text { interval }\end{array}$ & & & & \\
\hline $19 \mathrm{H}$ & $12 \mathrm{Jul}$ & 1855 & 104.3 & 104.4 & 0.1 & 104.3 & 104.47 & 0.17 & 170 & 1 & Half \\
\hline $20 \mathrm{H}$ & $12 \mathrm{Jul}$ & 2040 & 104.4 & 109.1 & 4.7 & 104.4 & 108.61 & 4.20 & 89 & 4 & Half \\
\hline \multicolumn{12}{|c|}{ 341-U1419D- } \\
\hline 11 & $13 \mathrm{Jul}$ & & & & $* * * * *$ Drilled & interval fro & $\mathrm{m} 0$ to 5.5 & $\mathrm{~m} \mathrm{DSF} * \star \star * *$ & & & \\
\hline $2 \mathrm{H}$ & 13 Jul & 0135 & 5.5 & 15.0 & 9.5 & 5.5 & 15.12 & 9.62 & 101 & 8 & Full \\
\hline $3 \mathrm{H}$ & $13 \mathrm{Jul}$ & 0205 & 15.0 & 24.5 & 9.5 & 15.0 & 25.29 & 10.08 & 106 & 8 & Full \\
\hline $4 \mathrm{H}$ & 13 Jul & 0235 & 24.5 & 34.0 & 9.5 & 24.5 & 34.94 & 9.91 & 104 & 8 & Full \\
\hline $5 \mathrm{H}$ & 13 Jul & 0305 & 34.0 & 43.5 & 9.5 & 34.0 & 44.38 & 9.89 & 104 & 8 & Full \\
\hline $6 \mathrm{H}$ & 13 Jul & 0335 & 43.5 & 43.6 & 0.1 & 43.5 & 43.56 & 0.06 & 60 & 1 & Full \\
\hline 71 & 13 Jul & \multicolumn{10}{|c|}{ 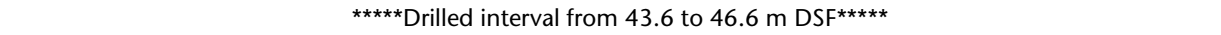 } \\
\hline $8 \mathrm{H}$ & $13 \mathrm{Jul}$ & 0415 & 46.6 & 47.4 & 0.8 & 46.6 & 47.42 & 0.82 & 102 & 1 & Full \\
\hline $9 \mathrm{H}$ & $13 \mathrm{Jul}$ & 0500 & 47.4 & 55.5 & 8.1 & 47.4 & 55.98 & 8.16 & 101 & 8 & Full \\
\hline $10 \mathrm{H}$ & $13 \mathrm{Jul}$ & 0600 & 55.5 & 63.0 & 7.5 & 55.5 & 64.10 & 8.20 & 109 & 7 & Full \\
\hline $11 \mathrm{H}$ & $13 \mathrm{Jul}$ & 0625 & 63.0 & 72.5 & 9.5 & 63.0 & 72.89 & 9.75 & 103 & 8 & Full \\
\hline $12 \mathrm{H}$ & $13 \mathrm{Jul}$ & 0710 & 72.5 & 72.7 & 0.2 & 72.5 & 72.79 & 0.29 & 145 & 1 & Full \\
\hline 131 & $13 \mathrm{Jul}$ & \multicolumn{10}{|c|}{${ }^{* \star * \star *}$ Drilled interval from 72.7 to $73.7 \mathrm{~m} \mathrm{DSF}^{\star * \star \star \star *}$} \\
\hline $14 \mathrm{H}$ & $13 \mathrm{Jul}$ & 0755 & 73.7 & 80.1 & 6.4 & 73.7 & 80.21 & 6.46 & 101 & 6 & Full \\
\hline $15 \mathrm{H}$ & $13 \mathrm{Jul}$ & 0855 & 80.1 & 84.8 & 4.7 & 80.1 & 83.66 & 3.56 & 76 & 4 & Half \\
\hline $16 \mathrm{H}$ & $13 \mathrm{Jul}$ & 0925 & 84.8 & 89.5 & 4.7 & 84.8 & 89.91 & 4.87 & 104 & 5 & Half \\
\hline $17 \mathrm{H}$ & 13 Jul & 1010 & 89.5 & 93.2 & 3.7 & 89.5 & 93.29 & 3.76 & 102 & 4 & Half \\
\hline $18 \mathrm{H}$ & 13 Jul & 1055 & 93.2 & 97.9 & 4.7 & 93.2 & 97.74 & 4.48 & 95 & 4 & Half \\
\hline $19 \mathrm{H}$ & $13 \mathrm{Jul}$ & 1135 & 97.9 & 102.6 & 4.7 & 97.9 & 102.58 & 4.57 & 97 & 5 & Half \\
\hline $20 \mathrm{H}$ & 13 Jul & 1205 & 102.6 & 107.3 & 4.7 & 102.6 & 107.49 & 4.73 & 101 & 5 & Half \\
\hline $21 \mathrm{H}$ & 13 Jul & 1230 & 107.3 & 107.4 & 0.1 & 107.3 & 107.35 & 0.05 & 50 & 1 & Half \\
\hline 221 & 13 Jul & \multicolumn{10}{|c|}{ 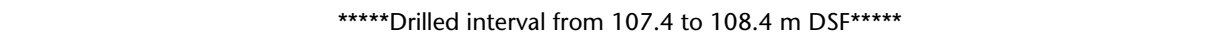 } \\
\hline $23 \mathrm{H}$ & 13 Jul & 1320 & 108.4 & 113.1 & 4.7 & 108.4 & 113.24 & 4.79 & 102 & 5 & Half \\
\hline $24 \mathrm{H}$ & $13 \mathrm{Jul}$ & 1405 & 113.1 & 114.2 & 1.1 & 113.1 & 114.15 & 1.05 & 95 & 2 & Half \\
\hline \multicolumn{12}{|c|}{ 341-U1419E- } \\
\hline 11 & 13 Jul & & & & 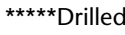 & interval fro & $\mathrm{n} 0$ to 9.0 & $\mathrm{~m} D S F^{\star \star \star \star \star *}$ & & & \\
\hline $2 \mathrm{H}$ & 13 Jul & 1720 & 9.0 & 18.5 & 9.5 & 9.0 & 18.71 & 9.71 & 102 & 8 & Full \\
\hline $3 \mathrm{H}$ & $13 \mathrm{Jul}$ & 1737 & 18.5 & 28.0 & 9.5 & 18.5 & 28.49 & 9.62 & 101 & 8 & Full \\
\hline $4 \mathrm{H}$ & 13 Jul & 1820 & 28.0 & 29.5 & 1.5 & 28.0 & 29.50 & 1.50 & 100 & 1 & Full \\
\hline 51 & $13 \mathrm{Jul}$ & \multicolumn{10}{|c|}{$\star \star \star \star * \star$ Drilled interval from 29.5 to $36.0 \mathrm{~m} \mathrm{DSF}{ }^{* * * \star *}$} \\
\hline $6 \mathrm{H}$ & 13 Jul & 1855 & 36.0 & 39.3 & 3.3 & 36.0 & 39.00 & 3.37 & 102 & 4 & Full \\
\hline 71 & $13 \mathrm{Jul}$ & \multicolumn{10}{|c|}{${ }^{\star \star \star \star \star *}$ Drilled interval from 39.3 to $46 \mathrm{~m} \mathrm{DSF} F^{\star \star \star \star *}$} \\
\hline $8 \mathrm{H}$ & $13 \mathrm{Jul}$ & 1945 & 46.0 & 48.3 & 2.3 & 46.0 & 48.31 & 2.31 & 100 & 3 & Full \\
\hline $9 \mathrm{H}$ & 13 Jul & 2030 & 48.3 & 50.9 & 2.6 & 48.3 & 50.69 & 2.61 & 100 & 3 & Full \\
\hline 101 & 13 Jul & \multicolumn{10}{|c|}{${ }^{\star \star \star \star \star}$ Drilled interval from 50.9 to $51.9 \mathrm{~m} \mathrm{DSF}{ }^{\star \star \star \star \star}$} \\
\hline $11 \mathrm{H}$ & 13 Jul & 2110 & 51.9 & 61.4 & 9.5 & 51.9 & 62.08 & 9.74 & 103 & 8 & Full \\
\hline $12 \mathrm{H}$ & $13 \mathrm{Jul}$ & 2210 & 61.4 & 69.0 & 7.6 & 61.4 & 69.03 & 7.63 & 100 & 6 & Full \\
\hline $13 \mathrm{H}$ & 13 Jul & 2315 & 69.0 & 73.7 & 4.7 & 69.0 & 74.06 & 4.93 & 105 & 5 & Half \\
\hline $14 \mathrm{H}$ & $13 \mathrm{Jul}$ & 2345 & 73.7 & 78.4 & 4.7 & 73.7 & 78.71 & 4.88 & 104 & 5 & Half \\
\hline $15 \mathrm{H}$ & $14 \mathrm{Jul}$ & 0010 & 78.4 & 83.1 & 4.7 & 78.4 & 81.91 & 3.31 & 70 & 4 & Half \\
\hline $16 \mathrm{H}$ & 14 Jul & 0035 & 83.1 & 87.8 & 4.7 & 83.1 & 84.36 & 1.26 & 27 & 1 & Half \\
\hline $17 \mathrm{H}$ & $14 \mathrm{Jul}$ & 0130 & 87.8 & 92.5 & 4.7 & 87.8 & 92.87 & 4.96 & 106 & 5 & Half \\
\hline $18 \mathrm{H}$ & 14 Jul & 0200 & 92.5 & 94.1 & 1.6 & 92.5 & 94.13 & 1.61 & 101 & 2 & Half \\
\hline $19 \mathrm{H}$ & 14 Jul & 0235 & 94.1 & 98.7 & 4.6 & 94.1 & 98.89 & 4.66 & 101 & 5 & Half \\
\hline
\end{tabular}

DSF $=$ drilling depth below seafloor, $C S F=$ core depth below seafloor. Core: $1=$ drilled interval, $\mathrm{H}=$ advanced piston corer $(\mathrm{APC})$ core, $\mathrm{X}=$ extended core barrel core. 
Table T2. Summary of observed lithofacies, Site U1419. (Continued on next two pages.)

\begin{tabular}{|c|c|c|c|c|c|c|}
\hline Main facies & Subfacies & Facies & Description & Marine microfossils & $\begin{array}{l}\text { Lithostratigraphic } \\
\text { unit }\end{array}$ & $\begin{array}{l}\text { Tentative depositional } \\
\text { environment/diagenesis }\end{array}$ \\
\hline \multirow[t]{2}{*}{ Mud } & $\begin{array}{l}\text { Massive mud with } \\
\text { lonestones }\end{array}$ & F1a & $\begin{array}{l}\text { (Dark) gray to (dark) greenish gray; } \\
\text { Facies thickness from } 3 \mathrm{~cm} \text { to } 10.82 \mathrm{~m} \text {; } \\
\text { Varying amounts of lonestones, as many as } 71 \text { per meter; subangular to subrounded } \\
\text { lonestones include siltstone, argillite, sandstone, basalt, granitoids, and chert; } \\
\text { Lonestones very rarely arranged in laminae; } \\
\text { Bioturbation mostly absent, occasionally slight to moderate; } \\
\text { Occasional occurrence of black mottles, shells and shell fragments, and pods of } \\
\text { silt and sand; } \\
\text { Very rare color banding and lamination, traces of ash, and occurrence of } \\
\text { diatoms, biosiliceous components, and foraminifers; } \\
\text { Interbedded with Facies F1c, F2a, F2b, F3a, F3c, F4d, F4e, F4f, F5a, F5b, F5c, } \\
\text { F6, and F7 }\end{array}$ & $\begin{array}{l}\text { Rare diatoms, } \\
\text { biosiliceous } \\
\text { components, and } \\
\text { foraminifers }\end{array}$ & I, II & $\begin{array}{l}\text { Suspension fall-out, ice rafting, } \\
\text { or sediment gravity flows }\end{array}$ \\
\hline & $\begin{array}{l}\text { Massive mud without } \\
\text { lonestones }\end{array}$ & $\mathrm{F} 1 \mathrm{~b}$ & $\begin{array}{l}\text { (Dark) gray to (dark) greenish gray; } \\
\text { Facies thickness from } 2 \mathrm{~cm} \text { to } 4.32 \mathrm{~m} \text {; } \\
\text { Occurs in Holes U1419B-U1419E; } \\
\text { Bioturbation mostly absent, very rarely slight bioturbation; } \\
\text { Occasionally with diatoms, foraminifers, silt, and sand; } \\
\text { Very rarely traces of ash, lamination, black mottles, and shell fragments; } \\
\text { Interbedded with Facies F1a, F2a, F2b, F3a, F3c, F4d, F4f, F5a, F5b, F5C, F6, } \\
\text { and F7 }\end{array}$ & $\begin{array}{l}\text { Rare diatoms and } \\
\text { foraminifers }\end{array}$ & 1 & $\begin{array}{l}\text { Suspension fall-out or } \\
\text { sediment gravity flows }\end{array}$ \\
\hline \multirow[t]{2}{*}{ Silt } & Silt & F2a & $\begin{array}{l}\text { (Very) dark gray; } \\
\text { Facies thickness from } 24 \mathrm{~cm} \text { to } 2.57 \mathrm{~m} ; \\
\text { Muddy silt, occasionally with foraminifers; } \\
\text { Occurring in Holes U1419A, U1419B, and U1419D; } \\
\text { Bioturbation mostly absent but rarely slight; } \\
\text { Lonestones absent or as many as } 30 \text { per meter, including siltstone, chert, } \\
\text { breccia, conglomerate, and greenstone; } \\
\text { Interbedded with Facies F1a, F1C, F2b, and F5b }\end{array}$ & $\begin{array}{l}\text { Occasional } \\
\text { foraminifers }\end{array}$ & 1 & $\begin{array}{l}\text { Sediment gravity flows and } \\
\text { possible ice rafting }\end{array}$ \\
\hline & $\begin{array}{l}\text { Interbedded/ } \\
\text { Interlaminated silt and } \\
\text { mud }\end{array}$ & $\mathrm{F} 2 \mathrm{~b}$ & $\begin{array}{l}\text { (Very) dark gray to dark greenish gray; } \\
\text { Facies thickness from } 8 \mathrm{~cm} \text { to } 3.92 \mathrm{~m} \text {; } \\
\text { Mostly graded silt laminae (occasionally beds) with sharp lower boundaries in } \\
\text { mud; } \\
\text { Maximum } 80 \text { laminae per meter but mostly }<40 \text { laminae per meter; } \\
\text { Bioturbation mostly absent but occasionally slight to moderate; } \\
\text { Few to absent lonestones; } \\
\text { Interbedded with Facies F1a, F1c, F2a, F3a, F5b, and F5c }\end{array}$ & Not documented & 1 & $\begin{array}{l}\text { Mud: suspension fall-out from } \\
\text { surface water plumes and } \\
\text { from sediment gravity flows } \\
\text { Silt: sediment gravity flows }\end{array}$ \\
\hline \multirow[t]{2}{*}{ Sand } & Very fine to coarse sand & F3a & $\begin{array}{l}\text { (Very) dark gray to (very) dark greenish gray; } \\
\text { Facies thickness from } 1 \text { to } 67 \mathrm{~cm} \text {; } \\
\text { Very fine to coarse sand (partly well sorted), massive to normally graded; } \\
\text { Occasionally sharp lower contacts; } \\
\text { Bioturbation absent; } \\
\text { Occasional occurrence of lonestones and foraminifers; } \\
\text { Interbedded with Facies F1a, F1c, F2b, F4e, F5a, F5b, and F7 }\end{array}$ & $\begin{array}{l}\text { Occasional } \\
\text { foraminifers }\end{array}$ & I, II & Sediment gravity flows \\
\hline & $\begin{array}{l}\text { Interbedded sand and } \\
\text { mud }\end{array}$ & $\mathrm{F} 3 \mathrm{c}$ & $\begin{array}{l}\text { Dark gray; } \\
\text { Facies thickness from } 4 \mathrm{~cm} \text { to } 1.93 \mathrm{~m} ; \\
\text { Interbedded (very) fine sand and mud occasionally with silt; } \\
\text { Sand laminae and beds as thick as } 3.5 \mathrm{~cm} ; \\
\text { Sandy beds typically graded and with erosive lower and sharp upper } \\
\text { boundaries; } \\
\text { Lonestones ( }<1 \mathrm{~cm} \text { ) occasionally present; } \\
\text { Mostly no bioturbation, occasionally rare bioturbation; } \\
\text { Present in Holes U1419A and U1419B; } \\
\text { Interbedded with Facies F1a, F1c, and F4e }\end{array}$ & Not documented & I, II & $\begin{array}{l}\text { Suspension fall-out from } \\
\text { surface water plumes (mud), } \\
\text { ice rafting (mud, sand, } \\
\text { lonestones), and sediment } \\
\text { gravity flows (sand, mud) }\end{array}$ \\
\hline
\end{tabular}


Table T2 (continued). (Continued on next page.)

\begin{tabular}{|c|c|c|c|c|c|c|}
\hline Main facies & Subfacies & Facies & Description & Marine microfossils & $\begin{array}{c}\text { Lithostratigraphic } \\
\text { unit }\end{array}$ & $\begin{array}{l}\text { Tentative depositional } \\
\text { environment/diagenesis }\end{array}$ \\
\hline \multirow[t]{3}{*}{ Diamict } & $\begin{array}{l}\text { Interbedded mud and } \\
\text { diamict }\end{array}$ & F4d & $\begin{array}{l}\text { Dark gray; } \\
\text { Facies thickness from } 53 \mathrm{~cm} \text { to } 3.48 \mathrm{~m} \text {; } \\
\text { Muddy matrix with diamicts of sandy/gravelly mud; } \\
\text { Diamict thickness between submillimeter and } 12 \mathrm{~cm} \text {; } \\
\text { Thicker beds have often gradational lower and sharp upper boundaries; } \\
\text { Diamict clasts up to } 5 \mathrm{~cm} \text {, including siltstone, granitoids, quartz, greenstone, } \\
\text { sandstone, and metasiltstone; } \\
\text { Very subtle color banding possible; } \\
\text { No bioturbation; } \\
\text { Occasionally with diatoms; } \\
\text { Present in Holes U1419A and U1419B; } \\
\text { Interbedded with Facies F1a, F1C, F4e, and F4f }\end{array}$ & Rare diatoms & II & $\begin{array}{l}\text { Suspension settling and ice } \\
\text { rafting (icebergs and/or sea } \\
\text { ice) }\end{array}$ \\
\hline & Clast-poor diamict & $\mathrm{F} 4 \mathrm{e}$ & $\begin{array}{l}\text { (Very) dark gray; } \\
\text { Facies thickness from } 20 \mathrm{~cm} \text { to } 3 \mathrm{~m} ; \\
\text { Muddy matrix, rarely silty or sandy; } \\
\text { Subrounded to subangular granule and pebble clasts including argillite, basalt, } \\
\text { shale, chert, conglomerate, diorite, feldspar, gneiss, granite, greenstone, } \\
\text { graywacke, metasediment with quartz veins, mudstone, potassium-feldspar- } \\
\text { rich fragment with thin foliation, sandstone with bioturbation, quartz, } \\
\text { rhyolite, sandstone (massive and laminated), and siltstone; } \\
\text { Present in Holes U1419A-U1419D; } \\
\text { Occasional lamination due to (1) clayish laminae and (2) sand/granule laminae } \\
\text { (<4 mm thick); } \\
\text { Occasional interbedding with slightly more clast-rich diamict; } \\
\text { Clast pods of coarse sand occasionally present (iceberg dump?); } \\
\text { Very rarely traces of volcanic ash; } \\
\text { Bioturbation absent; } \\
\text { Interbedded with Facies F1a, F3a, F3c, F4d, F4e, F4f, F5a, F5b, F5c, and F7 }\end{array}$ & Not documented & II & $\begin{array}{l}\text { Suspension settling and ice } \\
\text { rafting (ice rafting mainly by } \\
\text { icebergs) }\end{array}$ \\
\hline & Clast-rich diamict & $F 4 f$ & $\begin{array}{l}\text { (Very) dark gray; } \\
\text { Facies thickness from } 10 \mathrm{~cm} \text { to } 7.16 \mathrm{~m} \text {; } \\
\text { Mostly muddy and occasionally sandy matrix; } \\
\text { Subrounded to subangular granule and pebble clasts, including argillite, basalt, } \\
\text { black shale, chert, conglomerate, diorite, feldspar, granite, greenstone, } \\
\text { graywacke, metasediment with quartz veins, mudstone, quartz, rhyolite, } \\
\text { sandstone, and siltstone; } \\
\text { Very rarely trace amounts of volcanic ash and shell fragments; } \\
\text { Bioturbation absent; } \\
\text { Interstratification with mud laminae/beds possible (mud laminae may contain } \\
\text { diatoms); } \\
\text { Interbedded with Facies F1a, F1c, F4d, F4e, F5a, F5b, F5c, and F7 }\end{array}$ & Rare diatoms & I, II & $\begin{array}{l}\text { Suspension settling and ice } \\
\text { rafting (ice rafting mainly by } \\
\text { icebergs) }\end{array}$ \\
\hline Diatom ooze & & $\mathrm{F} 5 \mathrm{a}$ & $\begin{array}{l}\text { Olive gray to (very) dark greenish gray; } \\
\text { Facies thickness from } 3 \mathrm{~cm} \text { to } 6 \mathrm{~m} \text {; } \\
\text { Lonestones occasionally present; } \\
\text { Occasional scattered black mottles; } \\
\text { Mostly no but occasionally slight to heavy bioturbation; } \\
\text { Occasionally with foraminifers and radiolarians, as well as with sand and silt } \\
\quad \text { laminae; } \\
\text { Very occasionally trace amounts of ash; } \\
\text { Interbedded with Facies F1a, F1c, F3a, F4e, F4f, and F5c }\end{array}$ & $\begin{array}{l}\text { Diatoms; rare } \\
\text { radiolarians and } \\
\text { foraminifers }\end{array}$ & I, II & $\begin{array}{l}\text { High-productivity } \\
\text { environment and/or low } \\
\text { terrigenous input and/or } \\
\text { better preservation }\end{array}$ \\
\hline
\end{tabular}




\begin{tabular}{|c|c|c|c|c|c|c|}
\hline Main facies & Subfacies & Facies & Description & Marine microfossils & $\begin{array}{l}\text { Lithostratigraphic } \\
\text { unit }\end{array}$ & $\begin{array}{l}\text { Tentative depositional } \\
\text { environment/diagenesis }\end{array}$ \\
\hline $\begin{array}{l}\text { Biosiliceous ooze; } \\
\text { biosiliceous-rich/ } \\
\text { bearing mud and/ } \\
\text { or sand; mud with } \\
\text { diatoms/biosilica }\end{array}$ & & $\mathrm{F} 5 \mathrm{~b}$ & $\begin{array}{l}\text { Dark gray to (very dark) greenish gray; } \\
\text { Facies thickness from } 11 \mathrm{~cm} \text { to } 3.18 \mathrm{~m} \text {; } \\
\text { Diatom/biosiliceous-rich/bearing mud or mud with diatoms or radiolarians; } \\
\text { Occasionally with foraminifers and mud with sand; } \\
\text { Very rarely traces of volcanic ash, black mottles, shell fragments, and } \\
\text { lamination; } \\
\text { Bioturbation mostly absent but very rarely slight to moderate; } \\
\text { Occasional occurrence of up to pebble-sized lonestones, including argillite, } \\
\text { metastiltstone, granite, greenstone, and sandstone } \\
\text { Interbedded with Facies F1a, F1c, F2a, F2b, F3a, F4e, F4f, and F5c }\end{array}$ & $\begin{array}{l}\text { Diatoms, } \\
\text { foraminifers }\end{array}$ & I, II & $\begin{array}{l}\text { Temporarily increased } \\
\text { productivity and/or reduced } \\
\text { suspension settling and/or } \\
\text { better preservation }\end{array}$ \\
\hline $\begin{array}{l}\text { Calcareous/ } \\
\text { carbonate- } \\
\text { bearing/rich mud, } \\
\text { silt, sand, diamict, } \\
\text { and/or diatom } \\
\text { ooze }\end{array}$ & & $\mathrm{F} 5 \mathrm{c}$ & $\begin{array}{l}\text { Dark gray, dark greenish gray, grayish green, and very dark gray; } \\
\text { Facies thickness from } 3 \mathrm{~cm} \text { to } 1.5 \mathrm{~m} \text {; } \\
\text { With foraminifers or foraminifer-bearing mud, silt, sand, and diatom ooze; } \\
\text { Bioturbation mostly absent or rarely slight, very rare occurrence of nannofossils } \\
\text { and shell fragments; } \\
\text { Very rarely laminated deposits; } \\
\text { Occasional occurrence of lonestones; } \\
\text { Interbedded with Facies F1a, F1c, F2b, F4e, F4f, F5a, and F5b }\end{array}$ & $\begin{array}{l}\text { Foraminifers, } \\
\text { diatoms, } \\
\text { nannofossils }\end{array}$ & I, II & $\begin{array}{l}\text { Temporarily increased } \\
\text { productivity and/or reduced } \\
\text { suspension settling and/or } \\
\text { better preservation }\end{array}$ \\
\hline Ash & Volcanic ash & F6 & $\begin{array}{l}\text { Gray; } \\
\text { Facies thickness from } 2 \text { to } 4 \mathrm{~cm} \text {; } \\
\text { Bioturbation absent; } \\
\text { Occurs in Holes U1419B-U1419E; } \\
\text { Interbedded with Facies F1a and F1c }\end{array}$ & Not documented & 1 & $\begin{array}{l}\text { Suspension settling after } \\
\text { subaerial eruptions }\end{array}$ \\
\hline $\begin{array}{l}\text { Volcaniclastic mud, } \\
\text { sand, diamict, } \\
\text { and/or ooze }\end{array}$ & & F7 & $\begin{array}{l}\text { Dark gray to (very) dark greenish gray; } \\
\text { Facies thickness from } 2 \mathrm{~cm} \text { to } 5.29 \mathrm{~m} ; \\
\text { In diatom/biosiliceous ooze, diatom-rich/bearing mud, sandy clast-rich } \\
\quad \text { diamict, and mud with and without clasts; } \\
\text { Mostly trace amounts but very rarely volcaniclastic bearing; } \\
\text { Lonestones are present; } \\
\text { Bioturbation mostly absent but very rarely moderate; } \\
\text { Very occasional occurrence of foraminifers; } \\
\text { Occurs in Holes U1419A, U1419B, U1419C, and U1419E; } \\
\text { Interbedded with Facies F1a, F1C, F3a, F4e, and F4f }\end{array}$ & $\begin{array}{l}\text { Biosiliceous and } \\
\text { calcareous } \\
\text { microfossils }\end{array}$ & I, II & $\begin{array}{l}\text { Volcanic detritus either } \\
\text { bioturbated or reworked/ } \\
\text { redeposited by sediment } \\
\text { gravity flows }\end{array}$ \\
\hline
\end{tabular}

Table T3. Distribution of lithostratigraphic units and associated facies, Site U1419.

\begin{tabular}{|c|c|c|c|c|c|}
\hline $\begin{array}{l}\text { Lithostratigraphic } \\
\text { units and } \\
\text { associated facies }\end{array}$ & Hole U1419A & Hole U1419B & Hole U1419C & Hole U1419D & Hole U1419E \\
\hline $\begin{array}{l}\text { Unit I } \\
\text { F1a, F1b, F2a, F2b, } \\
\text { F3a, F3c, F4f, F5a, } \\
\text { F5b, F5c, F6, F7 }\end{array}$ & $\begin{array}{l}0-138.0 \mathrm{~m} \mathrm{CSF}-\mathrm{A} ; \\
\text { Interval } 1 \mathrm{H}-1,0 \mathrm{~cm} \text {, to } 23 \mathrm{X}-1,0 \\
\mathrm{~cm}\end{array}$ & $\begin{array}{l}0-95.5 \mathrm{~m} \mathrm{CSF}-\mathrm{A} \text {; } \\
\text { Interval } 1 \mathrm{H}-1,0 \mathrm{~cm} \text {, to } 14 \mathrm{H}-1,0 \\
\mathrm{~cm}\end{array}$ & $\begin{array}{l}0-2 \mathrm{~m} \text { CSF-A, drilled interval, } \\
2.0-88.3 \mathrm{~m} \text { CSF-A; } \\
\text { Interval } 2 \mathrm{H}-1,0 \mathrm{~cm} \text {, to } 14 \mathrm{H}-1 \text {, } \\
\quad 24 \mathrm{~cm}\end{array}$ & $\begin{array}{l}0-5.5 \mathrm{~m} \text { CSF-A, drilled interval, } \\
5.5-89.5 \mathrm{~m} \text { CSF-A; } \\
\text { Interval } 2 \mathrm{H}-1,0 \mathrm{~cm} \text {, to } 17 \mathrm{H}-1,0 \\
\quad \mathrm{~cm}\end{array}$ & $\begin{array}{l}\text { 0-9 m CSF-A, drilled interval, } \\
\text { 9-91.2 m CSF-A; } \\
\text { Core } 2 \mathrm{H}-1,0 \mathrm{~cm} \text {, to } 17 \mathrm{H}-3,60 \\
\quad \text { cm }\end{array}$ \\
\hline $\begin{array}{l}\text { Unit II } \\
\text { F1a, F3a, F3c, F4d, } \\
\text { F4e, F4f, F5a, F5b, } \\
\text { F5c, F7 }\end{array}$ & $\begin{array}{l}138.0-189.7 \mathrm{~m} \text { CSF-A; } \\
\text { Interval 23X-1, } 0 \mathrm{~cm} \text {, to } 29 \mathrm{X}-\mathrm{CC} \text {, } \\
18 \mathrm{~cm}\end{array}$ & $\begin{array}{l}\text { 95.5-114.0 m CSF-A; } \\
\text { Interval } 14 \mathrm{H}-1,0 \mathrm{~cm} \text {, to } 19 \mathrm{H}- \\
\text { CC, } 26 \mathrm{~cm}\end{array}$ & $\begin{array}{l}88.3-108.6 \mathrm{~m} \text { CSF-A; } \\
\text { Interval } 14 \mathrm{H}-1,24 \mathrm{~cm} \text {, to } 20 \mathrm{H}- \\
\text { CC, } 27 \mathrm{~cm}\end{array}$ & $\begin{array}{l}89.5-114.1 \mathrm{~m} \text { CSF-A; } \\
\text { Interval } 17 \mathrm{H}-1,0 \mathrm{~cm} \text {, to } 24 \mathrm{H}- \\
\text { CC, } 45 \mathrm{~cm}\end{array}$ & $\begin{array}{l}91.2-98.9 \mathrm{~m} \text { CSF-A; } \\
\text { Interval } 17 \mathrm{H}-3,60 \mathrm{~cm} \text {, to } 19 \mathrm{H}- \\
\quad \text { CC, } 30 \mathrm{~cm}\end{array}$ \\
\hline
\end{tabular}


Table T4. XRD mineral composition, Site U1419.

\begin{tabular}{|c|c|c|c|c|c|c|c|c|c|c|}
\hline \multirow{2}{*}{$\begin{array}{l}\text { Core, section, } \\
\text { interval }(\mathrm{cm})\end{array}$} & \multicolumn{2}{|c|}{ Top depth (m) } & \multirow{2}{*}{$\begin{array}{l}\text { Mica } \\
\text { (counts) }\end{array}$} & \multirow{2}{*}{$\begin{array}{l}\text { Hornblende } \\
\text { (counts) }\end{array}$} & \multirow{2}{*}{$\begin{array}{c}\text { Chlorite + } \\
\text { kaolinite } \\
\text { (counts) }\end{array}$} & \multirow{2}{*}{$\begin{array}{l}\text { Total clays } \\
\text { (counts) }\end{array}$} & \multirow{2}{*}{$\begin{array}{l}\text { Quartz } \\
\text { (counts) }\end{array}$} & \multirow{2}{*}{$\begin{array}{l}\text { Plagioclase } \\
\text { (counts) }\end{array}$} & \multirow{2}{*}{$\begin{array}{l}\text { Calcite } \\
\text { (counts) }\end{array}$} & \multirow{2}{*}{$\begin{array}{l}\text { Pyrite } \\
\text { (counts) }\end{array}$} \\
\hline & CSF-A & CCSF-B & & & & & & & & \\
\hline \multicolumn{11}{|l|}{ 341-U1419A- } \\
\hline $1 \mathrm{H}-1,60-61$ & 0.60 & 0.50 & 5,440 & 5,998 & 9,276 & 2,804 & 6,138 & 7,010 & 2,961 & 2,685 \\
\hline $2 \mathrm{H}-3,48-49$ & 10.88 & 7.97 & 6,417 & 5,998 & 7,986 & 2,710 & 7,602 & 7,742 & 3,330 & 2,420 \\
\hline $3 \mathrm{H}-1,31-32$ & 17.21 & 15.97 & 7,219 & 9,520 & 8,509 & 2,448 & 9,102 & 11,508 & 3,697 & 2,312 \\
\hline $6 \mathrm{H}-5,134-135$ & 46.24 & 45.28 & 6,486 & 8,404 & 9,974 & 2,553 & 6,905 & 9,451 & 3,320 & 2,469 \\
\hline $8 \mathrm{H}-1,112-113$ & 59.02 & 58.14 & 6,138 & 6,626 & 10,113 & 2,793 & 6,242 & 8,160 & 3,128 & 2,856 \\
\hline $9 \mathrm{H}-3,60-61$ & 71.01 & 68.67 & 7,044 & 7,568 & 11,857 & 2,762 & 6,835 & 8,823 & 4,743 & 2,807 \\
\hline $10 \mathrm{H}-3,39-40$ & 78.00 & 76.30 & 7,986 & 8,718 & 10,985 & 2,720 & 8,265 & 8,962 & 3,627 & 2,724 \\
\hline $11 \mathrm{H}-1,31-32$ & 84.81 & 84.03 & 5,580 & 5,684 & 5,998 & 2,731 & 6,556 & 7,707 & 3,557 & 3,358 \\
\hline $12 \mathrm{H}-2,60-61$ & 90.20 & 88.91 & 5,615 & 4,394 & 7,463 & 2,664 & 7,812 & 7,602 & 3,166 & 2,459 \\
\hline $14 \mathrm{H}-2,60-61$ & 100.50 & 98.12 & 5,336 & 4,534 & 7,289 & 2,832 & 6,835 & 7,881 & 3,592 & 2,525 \\
\hline $15 \mathrm{H}-1,83-84$ & 103.93 & 100.59 & 7,428 & 5,963 & 9,137 & 2,657 & 6,905 & 9,799 & 3,731 & 2,420 \\
\hline $16 \mathrm{H}-2,83-84$ & 106.93 & 104.57 & 6,591 & 4,499 & 8,474 & 2,835 & 6,382 & 6,940 & 3,393 & 2,267 \\
\hline $17 \mathrm{H}-1,41-42$ & 109.81 & 109.81 & 5,615 & 4,917 & 7,637 & 2,790 & 7,323 & 7,707 & 3,323 & 2,528 \\
\hline $18 \mathrm{H}-2,41-42$ & 115.71 & 115.71 & 8,579 & 3,836 & 6,347 & 2,752 & 7,707 & 7,602 & 2,755 & 2,159 \\
\hline $23 X-1,54-55$ & 138.54 & 138.54 & 7,777 & 4,847 & 10,078 & 2,643 & 6,975 & 9,137 & 3,592 & 2,392 \\
\hline $24 X-2,34-35$ & 149.05 & 149.05 & 8,021 & 5,510 & 10,009 & 2,535 & 8,404 & 13,810 & 2,989 & 2,134 \\
\hline $26 \mathrm{X}-1,44-45$ & 167.54 & 167.54 & 7,219 & 7,637 & 9,486 & 2,581 & 6,033 & 8,544 & 4,080 & 2,542 \\
\hline
\end{tabular}

Table T5. Diatoms, Site U1419. This table is available in an oversized format.

Table T6. Radiolarians, Site U1419. This table is available in an oversized format. 
Table T7. Planktonic foraminifers, Site U1419.

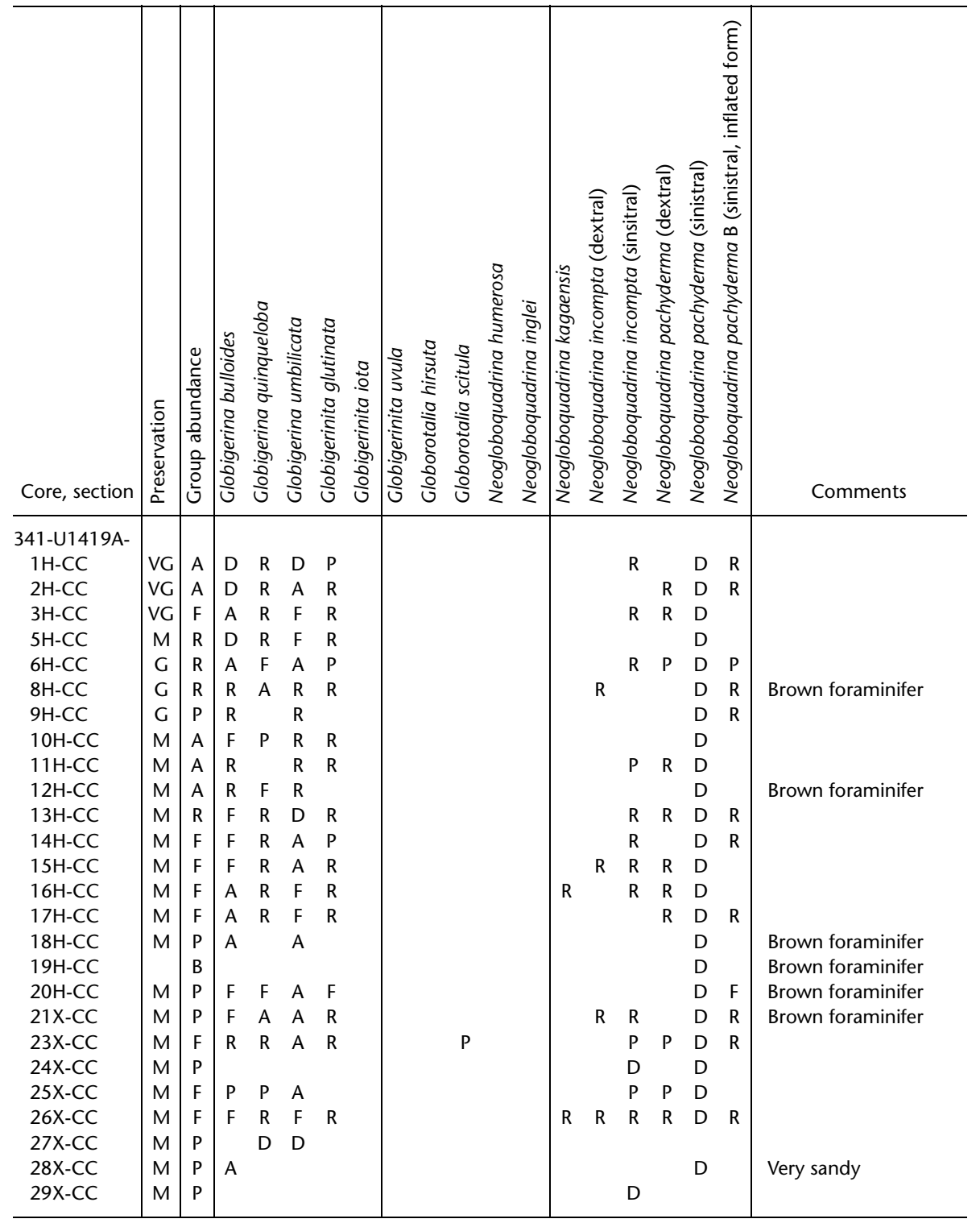

Preservation: $V G=$ very good, $G=$ good, $M=$ moderate. Abundance: $D=$ dominant, $A=$ abundant, $F=$ few, $R=$ rare, $P=$ present, $B=$ barren. This table is also available in .CSV. 
Table T8. Benthic foraminifers, Site U1419.

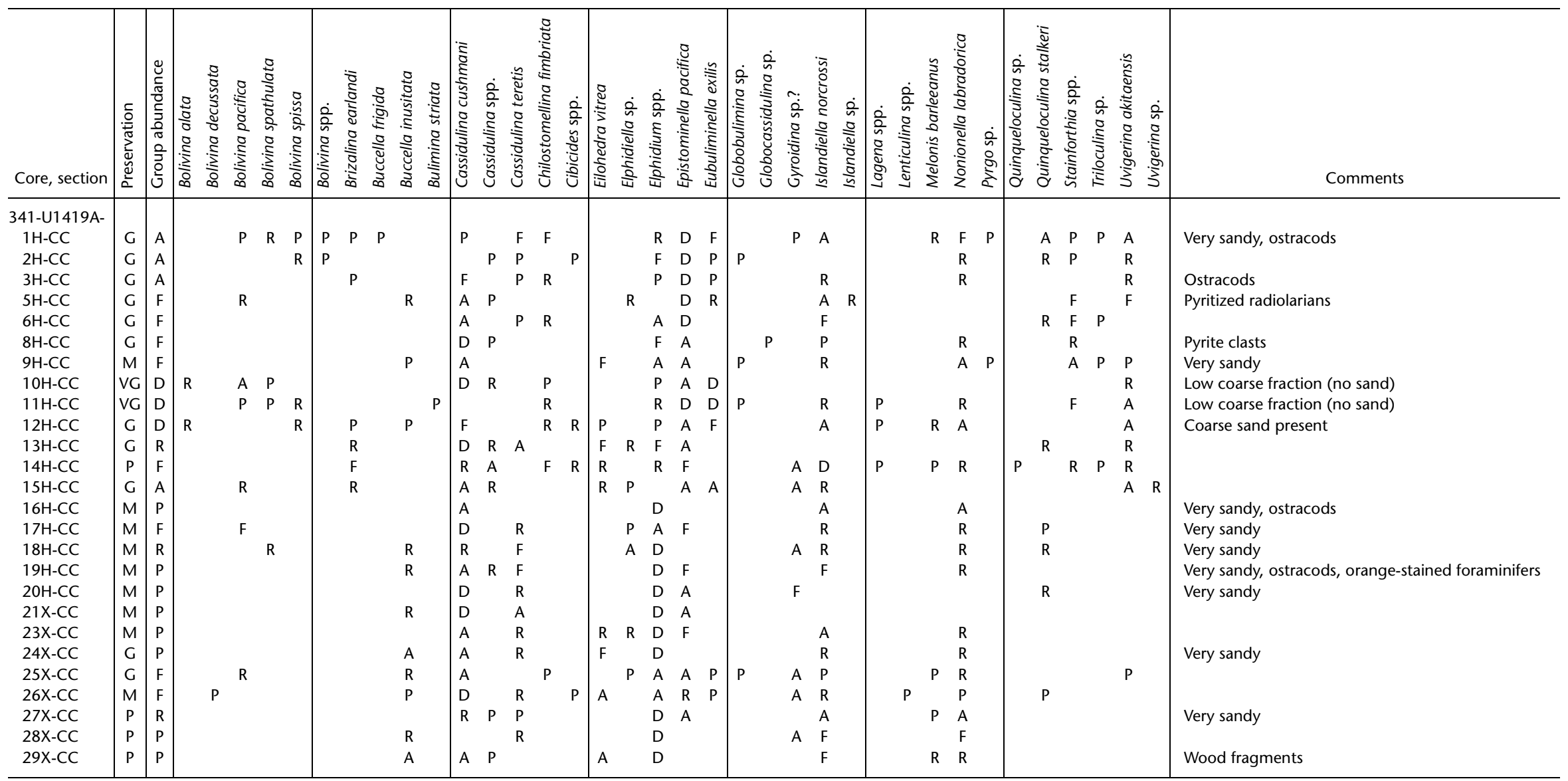

Preservation: $\mathrm{VG}=$ very good, $\mathrm{G}=$ good, $\mathrm{M}=$ moderate, $\mathrm{P}=$ poor. Abundance: $\mathrm{D}=$ dominant, $\mathrm{A}=$ abundant, $\mathrm{F}=$ few, $\mathrm{R}=$ rare, $\mathrm{P}=$ present. This table is also available in. $\mathrm{CSV}$. 
Table T9. Affine table, Site U1419.

\begin{tabular}{|c|c|c|c|}
\hline Core & Offset (m) & Core & Offset (m) \\
\hline 341-U1419A- & & $11 \mathrm{H}$ & 18.71 \\
\hline $1 \mathrm{H}$ & -0.02 & $12 \mathrm{H}$ & 20.28 \\
\hline $2 \mathrm{H}$ & -1.56 & $13 \mathrm{H}$ & 20.17 \\
\hline $3 \mathrm{H}$ & 1.47 & $14 \mathrm{H}$ & 20.90 \\
\hline $4 \mathrm{H}$ & No core recovery & $15 \mathrm{H}$ & 23.10 \\
\hline $5 \mathrm{H}$ & $1 \%$ recovery & $16 \mathrm{H}$ & 23.60 \\
\hline $6 \mathrm{H}$ & 6.72 & $17 \mathrm{H}$ & 24.37 \\
\hline $7 \mathrm{H}$ & No core recovery & $18 \mathrm{H}$ & No core recovery \\
\hline $8 \mathrm{H}$ & 8.98 & $19 \mathrm{H}$ & Only $17 \mathrm{~cm}$ \\
\hline $9 \mathrm{H}$ & 10.76 & $20 \mathrm{H}$ & 30.21 \\
\hline $10 \mathrm{H}$ & 14.36 & 341-U1419D- & \\
\hline $11 \mathrm{H}$ & 18.27 & $2 \mathrm{H}$ & 0.24 \\
\hline $12 \mathrm{H}$ & 19.65 & $3 \mathrm{H}$ & 1.40 \\
\hline $13 \mathrm{H}$ & 21.66 & $4 \mathrm{H}$ & 3.59 \\
\hline $14 \mathrm{H}$ & 22.14 & $5 \mathrm{H}$ & 5.54 \\
\hline $15 \mathrm{H}$ & $\begin{array}{l}22.12 \\
24.65\end{array}$ & $6 \mathrm{H}$ & Only $6 \mathrm{~cm}$ \\
\hline $16 \mathrm{H}$ & 24.65 & 71 & No core recovery \\
\hline $17 \mathrm{H}$ & 28.66 & $8 \mathrm{H}$ & 3.29 \\
\hline $18 \mathrm{H}$ & 28.66 & $9 \mathrm{H}$ & 4.45 \\
\hline $19 \mathrm{H}$ & $\begin{array}{l}28.66 \\
28.66\end{array}$ & $10 \mathrm{H}$ & 9.60 \\
\hline $\begin{array}{l}20 x \\
21 x\end{array}$ & $\begin{array}{l}28.66 \\
28.66\end{array}$ & $11 \mathrm{H}$ & 11.76 \\
\hline $\begin{array}{l}21 X \\
22 X\end{array}$ & $\begin{array}{l}28.66 \\
\text { No core recovery }\end{array}$ & $12 \mathrm{H}$ & Only $29 \mathrm{~cm}$ \\
\hline $\begin{array}{l}22 X \\
23 X\end{array}$ & $\begin{array}{c}\text { No core recovery } \\
28.66\end{array}$ & 131 & No core recovery \\
\hline $\begin{array}{l}23 X \\
24 X\end{array}$ & $\begin{array}{l}28.66 \\
28.66\end{array}$ & $14 \mathrm{H}$ & 14.48 \\
\hline $\begin{array}{l}24 X \\
25 X\end{array}$ & $\begin{array}{l}28.66 \\
28.66\end{array}$ & $15 \mathrm{H}$ & 19.60 \\
\hline $\begin{array}{l}25 X \\
26 X\end{array}$ & $\begin{array}{l}28.66 \\
28.66\end{array}$ & $16 \mathrm{H}$ & 18.68 \\
\hline $\begin{array}{l}26 X \\
27 X\end{array}$ & $\begin{array}{l}28.66 \\
28.66\end{array}$ & $17 \mathrm{H}$ & 20.16 \\
\hline $\begin{array}{l}27 X \\
28 X\end{array}$ & $\begin{array}{l}28.66 \\
28.66\end{array}$ & $18 \mathrm{H}$ & 23.51 \\
\hline $\begin{array}{l}28 X \\
29 x\end{array}$ & $\begin{array}{l}28.66 \\
28.66\end{array}$ & $19 \mathrm{H}$ & 23.74 \\
\hline $29 \mathrm{X}$ & 28.66 & $20 \mathrm{H}$ & 25.74 \\
\hline 341-U1419B- & & $21 \mathrm{H}$ & Only $5 \mathrm{~cm}$ \\
\hline $1 \mathrm{H}$ & 0.00 & 221 & No core recovery \\
\hline $2 \mathrm{H}$ & 1.25 & $23 \mathrm{H}$ & 29.10 \\
\hline $3 \mathrm{H}$ & 1.80 & $24 \mathrm{H}$ & 29.10 \\
\hline $4 \mathrm{H}$ & 4.54 & 341-U1419E- & \\
\hline $5 \mathrm{H}$ & 5.94 & $2 \mathrm{H}$ & 0.60 \\
\hline $6 \mathrm{H}$ & 8.33 & $3 \mathrm{H}$ & 1.52 \\
\hline $7 \mathrm{H}$ & 8.20 & $4 \mathrm{H}$ & 3.71 \\
\hline $8 \mathrm{H}$ & 10.36 & 51 & No core recovery \\
\hline $9 \mathrm{H}$ & $\begin{array}{l}11.53 \\
17.06\end{array}$ & $6 \mathrm{H}$ & 2.07 \\
\hline $\begin{array}{l}10 \mathrm{H} \\
11 \mathrm{H}\end{array}$ & $\begin{array}{l}17.06 \\
19.35\end{array}$ & 71 & No core recovery \\
\hline $\begin{array}{l}11 \mathrm{H} \\
12 \mathrm{H}\end{array}$ & $\begin{array}{l}19.35 \\
19.58\end{array}$ & $8 \mathrm{H}$ & 2.58 \\
\hline $\begin{array}{l}12 \mathrm{H} \\
13 \mathrm{H}\end{array}$ & $\begin{array}{l}19.58 \\
17.88\end{array}$ & $9 \mathrm{H}$ & 6.77 \\
\hline $\begin{array}{l}13 \mathrm{H} \\
14 \mathrm{H}\end{array}$ & $\begin{array}{l}17.88 \\
21.16\end{array}$ & 101 & No core recovery \\
\hline $\begin{array}{l}14 \mathrm{H} \\
15 \mathrm{H}\end{array}$ & $\begin{array}{l}21.16 \\
25.30\end{array}$ & $11 \mathrm{H}$ & 9.17 \\
\hline $\begin{array}{l}15 \mathrm{H} \\
16 \mathrm{H}\end{array}$ & $\begin{array}{l}23.30 \\
27.60\end{array}$ & $12 \mathrm{H}$ & 10.72 \\
\hline $\begin{array}{l}16 \mathrm{H} \\
17 \mathrm{H}\end{array}$ & No core recovery & $13 \mathrm{H}$ & 13.21 \\
\hline $\begin{array}{l}17 \mathrm{H} \\
181\end{array}$ & No core recovery & $14 \mathrm{H}$ & 15.09 \\
\hline $\begin{array}{l}181 \\
19 \mathrm{H}\end{array}$ & 30.54 & $15 \mathrm{H}$ & 18.30 \\
\hline $19 \mathrm{H}$ & & $16 \mathrm{H}$ & 19.77 \\
\hline 341-U1419C- & & $17 \mathrm{H}$ & 19.53 \\
\hline 11 & 0.00 & $18 \mathrm{H}$ & 20.47 \\
\hline $2 \mathrm{H}$ & 0.42 & $19 \mathrm{H}$ & 22.96 \\
\hline
\end{tabular}

Core: $\mathrm{H}=$ advanced piston corer, $\mathrm{X}=$ extended core barrel. Cores with very low recovery were not used for correlation purposes. 
Table T10. Splice tie points, Site U1419.

\begin{tabular}{|c|c|c|c|c|c|c|c|c|}
\hline $\begin{array}{l}\text { Hole, core, } \\
\text { section }\end{array}$ & $\begin{array}{l}\text { Tie point } \\
\text { (cm) }\end{array}$ & $\begin{array}{l}\text { Depth } \\
\text { CSF-A } \\
\text { (m) }\end{array}$ & $\begin{array}{l}\text { Depth } \\
\text { CCSF-A } \\
\text { (m) }\end{array}$ & $\begin{array}{c}\text { Tie/ } \\
\text { Append }\end{array}$ & $\begin{array}{l}\text { Hole, core, } \\
\text { section }\end{array}$ & $\begin{array}{l}\text { Tie point } \\
\text { (cm) }\end{array}$ & $\begin{array}{c}\text { Depth } \\
\text { CSF-A } \\
(\mathrm{m})\end{array}$ & $\begin{array}{c}\text { Depth } \\
\text { CCSF-A } \\
\text { (m) }\end{array}$ \\
\hline $341-$ & & & & & $341-$ & & & \\
\hline U1419B-1H-5 & 118.38 & 7.18 & 7.18 & Tie to & U1419D-2H-1 & 144.54 & 6.95 & 7.18 \\
\hline U1419D-2H-6 & 111.25 & 14.11 & 14.35 & Tie to & U1419E-2H-4 & 25.21 & 13.75 & 14.35 \\
\hline U1419E-2H-7 & 2.75 & 17.93 & 18.53 & Tie to & U1419D-3H-2 & 63.11 & 17.13 & 18.53 \\
\hline U1419D-3H-6 & 109.75 & 23.51 & 24.90 & Tie to & U1419E-3H-4 & 55.75 & 23.39 & 24.90 \\
\hline U1419E-3H-7 & 92.83 & 28.13 & 29.64 & Tie to & U1419D-4H-2 & 5.71 & 26.06 & 29.64 \\
\hline U1419D-4H-5 & 102.80 & 31.41 & 34.99 & Tie to & U1419B-4H-3 & 7.89 & 30.46 & 34.99 \\
\hline U1419B-4H-7 & 37.49 & 36.60 & 41.14 & Tie to & U1419D-5H-2 & 16.04 & 35.60 & 41.14 \\
\hline U1419D-5H-6 & 52.87 & 41.85 & 47.39 & Tie to & U1419C-6H-2 & 31.21 & 40.93 & 47.39 \\
\hline U1419C-6H-7 & 102.68 & 48.88 & 55.33 & Tie to & U1419D-9H-3 & 51.21 & 50.88 & 55.33 \\
\hline U1419D-9H-7 & 69.20 & 55.61 & 60.06 & Tie to & U1419B-7H-1 & 146.06 & 51.86 & 60.06 \\
\hline U1419B-7H-7 & 20.37 & 59.32 & 67.53 & Tie to & U1419D-10H-2 & 97.97 & 57.93 & 67.53 \\
\hline U1419D-10H-6 & 6.79 & 62.93 & 72.52 & Tie to & U1419E-12H-1 & 40.83 & 61.81 & 72.52 \\
\hline U1419E-12H-5 & 88.16 & 68.28 & 79.00 & Tie to & U1419A-9H-1 & 83.75 & 68.24 & 79.00 \\
\hline U1419A-9H-3 & 48.62 & 70.90 & 81.66 & Tie to & U1419B-9H-1 & 82.24 & 70.12 & 81.66 \\
\hline U1419B-9H-6 & 135.14 & 77.80 & 89.34 & Tie to & U1419E-14H-1 & 54.66 & 74.25 & 89.34 \\
\hline U1419E-14H-4 & 14.64 & 77.88 & 92.97 & Tie to & U1419A-10H-3 & 99.95 & 78.61 & 92.97 \\
\hline U1419A-10H-6 & 65.74 & 82.61 & 96.96 & Tie to & U1419E-15H-1 & 26.18 & 78.66 & 96.96 \\
\hline U1419E-15H-3 & 17.29 & 81.19 & 99.49 & Tie to & U1419C-12H-1 & 51.89 & 79.22 & 99.49 \\
\hline U1419C-12H-4 & 47.61 & 83.35 & 103.62 & Tie to & U1419D-16H-1 & 14.29 & 84.94 & 103.62 \\
\hline U1419D-16H-3 & 101.75 & 88.78 & 107.46 & Tie to & U1419B-12H-1 & 138.11 & 87.88 & 107.46 \\
\hline U1419B-12H-2 & 135.74 & 89.36 & 108.93 & Tie to & U1419E-17H-2 & 18.48 & 89.40 & 108.93 \\
\hline U1419E-17H-2 & 18.48 & 89.40 & 108.93 & Append & U1419E-17H-4 & 0.64 & 92.57 & 112.10 \\
\hline
\end{tabular}

Tie points in bold reflect tentative correlations. See text for details.

Table T11. Alternating field demagnetization steps used, Site U1419.

\begin{tabular}{cll}
\hline Hole & Cores undertaken & $\begin{array}{c}\text { AF demagnetization } \\
\text { steps }(\mathrm{mT})\end{array}$ \\
\hline U1419A & All cores & $0,10,20$ \\
U1419B & 1H & $0,5,10,15,20$ \\
U1419B & 2H through 19H & $0,10,20$ \\
U1419C & 2H & $0,5,10,15,20$ \\
U1419C & 3H through 20H & $0,10,20$ \\
U1419D & All cores & $0,10,20$ \\
U1419E & All cores & $0,10,20$ \\
\hline
\end{tabular}

